\title{
Coupled Environmental Processes and Long-term Performance of Landfill Covers in the northern Mojave Desert
}

\author{
Prepared by \\ David S. Shafer, Michael H. Young, Stephen F. Zitzer, \\ Eric McDonald and Todd Caldwell
}

Submitted to

Nevada Site Office

National Nuclear Security Administration

U.S. Department of Energy

Las Vegas, Nevada

FEBRUARY 2004

Publication No. 45203 
Reference herein to any specific commercial product, process, or service by trade name, trademark, manufacturer, or otherwise, does not necessarily constitute or imply its endorsement, recommendation, or favoring by the United States Government or any agency thereof or its contractors or subcontractors. The views and opinions of authors expressed herein do not necessarily state or reflect those of the United States Government or any agency thereof.

This report has been reproduced directly from the best available copy.

Available for sale to the public from:

\author{
U.S. Department of Commerce \\ National Technical Information Service \\ 5285 Port Royal Road \\ Springfield, VA 22161 \\ Phone: 800.553.6847 \\ Fax: 703.605.6900 \\ Email: orders@ntis.gov \\ Online ordering: http://www.ntis.gov/ordering.htm
}

Available electronically at http://www.osti.gov/bridge

Available for a processing fee to the U.S. Department of Energy and its contractors, in paper, from:

U.S. Department of Energy

Office of Scientific and Technical Information

P.O. Box 62

Oak Ridge, TN 37831-0062

Phone: 865.576.8401

Fax: 865.576.5728

Email: reports@adonis.osti.gov 


\title{
Coupled Environmental Processes and Long-term Performance of Landfill Covers in the northern Mojave Desert
}

\author{
Prepared by \\ David S. Shafer, Michael H. Young, Stephen F. Zitzer, \\ Eric McDonald and Todd Caldwell \\ Desert Research Institute \\ University and Community College System of Nevada
}

Publication No. 45203

\author{
Submitted to \\ Nevada Site Office \\ National Nuclear Security Administration \\ U.S. Department of Energy \\ Las Vegas, Nevada
}

February 2004

The work upon which this report is based was supported by the U.S. Department of Energy under Contract \#DE-AC52-00NV13609. Approved for public release; further dissemination unlimited. 
This page intentionally left blank 


\section{EXECUTIVE SUMMARY}

Evapotranspiration (ET) covers have gained widespread acceptance as a closure feature for waste disposal sites, particularly in arid and semi-arid regions of the southwestern United States. In addition, monolayer ET covers have been selected as the baseline method for closure of waste disposal sites for low-level radioactive (LLW), mixed LLW, and transuranic (TRU) waste disposal sites at the Nevada Test Site (NTS). However, ET covers are also landforms that will be subject to environmental change over time because of processes such as pedogenesis, hydrologic processes, vegetation establishment and change, and biological processes. Often these processes are viewed individually, when, in fact, in most cases they are interrelated or coupled.

To better understand the effects of coupled process changes to ET covers, a series of four primary analog sites in Yucca Flat on the NTS, along with measurements and observations from other locations in the Mojave Desert, were selected to evaluate changes in ET covers over time. An important assumption in selecting a temporal sequence of analog sites is that looking back in time provides evidence of how similar features will change in the future. The ET cover constructed for the U3axbl waste cell in the Area 3 Radioactive Waste Management Site of the NTS was used as a baseline for comparison. Field and laboratory studies and literature reviews were conducted to evaluate the possible impacts of change on performance objectives of ET covers elucidated in U.S. Department of Energy, National Nuclear Security Administration Nevada Site Office (NNSA/NSO) Waste Management Program "Integrated Closure and Monitoring Plan" for the NTS. Performance criteria include 1) that the cover provides long-term minimization of migration of liquids through the landfill; 2) that the cover function with minimum maintenance; and 3) that the cover promotes drainage, with minimal erosion or abrasion. Analyses were also carried out to address NNSA/NSO technology needs for ET covers including providing information "on long-term evolution... of these covers as landform features that change because of natural pedogenic, biotic, and climatic processes; and maintaining functional requirements including 'limiting infiltration' and maintaining 'effective high ET ability."'

The analog sites (approximately 30 years, 1,000 to 2,000 years, 7,000 to 12,500 years, and approximately 125,000 years in age) were selected to addresses changes in the early post-institutional control period (the youngest site), the 1,000-year compliance period for disposal of LLW and mixed LLW, and the 10,000-year compliance period for TRU waste sites. Analog sites were selected based on criteria that included: 1) evidence that the sites had been isolated from recent alluvial, colluvial, and erosion processes that would not be expected to be agents on newly constructed ET covers; 2) low surface gradients, eliminating the need to consider processes such as sheet wash that a newly constructed cover would also be designed not to experience; 3) minimal anthropomorphic impacts, or, if present, that their impacts were clearly distinguished from natural processes; and 4) that some means of obtaining age control could be established for the site. Tests conducted as part of this study include soil texture, structure, and surface morphology; infiltration and hydraulic conductivity surveys; vegetation and faunal surveys; and literature reviews. At each of the analog sites, separate measurements for soil texture, structure, and soil hydraulic properties were made in plant undercanopy and intercanopy areas, assuming that the changes in these subsets of the cover environment could be different. At the youngest analog site where vegetation recruitment was underway, vegetation was compared to that of mature vegetation 
on the nearby oldest analog site to evaluate whether colonizing native plants on "new covers" was similar to that of surrounding native vegetation.

Among the trends observed is that, at progressively older analog sites to about 10,000 years in the area of study, there is good evidence for increased perennial plant cover (maximum approximately 35 percent), both from live and dead shrubs. Surveys of the density and location of animal burrows show a strong preference for faunal activity in the vicinity of perennial shrubs, the so-called "fertile island effect." The shrub "islands" develop mounds around them from small mammal burrowing and soil accumulation, and the deposition of leaf litter. Out to sites of age range of 1,000 to 2,000 years, interplant spaces are occupied with winter annual grasses and forbs that take advantage of irregularities in the soil surface as recruitment sites. Irregularities in the soil surface, including those created by small mammal activity, probably promote the entrapment of eolian fine-grained sediments and provide for localized areas of focused infiltration, processes that aid plant establishment. In soils of this age, only incipient desert pavement development has occurred. Plant species composition of the vegetation that is colonizing the youngest analog site shows little similarity with native vegetation on surrounding sites (including Analog Site 4). Instead, the vegetation is dominated by species that colonize disturbed areas elsewhere on the NTS, although some of the species (e.g., Mormon tea [Ephedra nevadensis]) remain dominant species until at least approximately 10,000 years.

The most significant soil-forming process observed is the eolian deposition of silts and clays, leading eventually to the development of well-developed vesicular Av horizons in sites of approximately 10,000 years. The Av horizon development leads to reduced infiltration and greater water-holding capacity in the upper soil profiles. With the development of soil structure, including the development of eolian depositional features, saturated hydraulic conductivity (Ksat) decreased with time, although the magnitude of the decrease was higher (fivefold) in the intercanopy areas than in undercanopy areas. The lower degree of the Ksat change in undercanopy areas can probably be attributed to the bioturbation of near-surface soil horizons, locally preventing the vesicular Av horizon from developing. The trend of decreasing infiltration rate and Ksat with increasing age of these sites is similar to trends measured in similar, small-scale areas of the Mojave National Preserve in California (Young et al., 2003), although the decrease in Ksat values at the Yucca Flat analog sites was found to be less.

Perhaps most significantly for long-term performance of ET covers on waste containment cells is that soils may evolve naturally with morphological and structural characteristics that progressively confine surface penetrating moisture to the uppermost profile of the cover. These same morphological changes appear to also limit the depth of root penetration and bioturbation by small mammals, but not so much that the rooting depth of plants is inhibited in removing storage water in the cover. However, on all the analog sites, small mammal bioturbation is largely limited to the upper $70 \mathrm{~cm}$ of the soil column. Beginning approximately after 10,000 years, the percent cover of plants may begin to decline, potentially limiting the role of transpiration of plants in meeting cover performance criteria. However, this occurs concomitantly with the development of greater degrees of desert pavement that provides erosion protection that would otherwise be provided by plants, and the formation of a near-surface Av soil horizon whose water-holding capacity further restricts deep-water infiltration, and allows water to remain closer to ground surface, where 
evapotranspirative processes are more likely to remove the water. The partitioning of potential ET into soil evaporation and plant transpiration would, hence, change as the soil surface changes.

What cannot be evaluated at this time is the impact of the coupled processes studied on all potential exposure or contaminant release pathways of concern from waste disposal systems at the NTS. The NNSA/NSO Waste Management Program is in the process of evaluating the feasibility of new waste streams (e.g., those that produce high radon flux) and considering multiple closure strategies (e.g., many individuals closures with ET covers as opposed to larger cover systems that would enclose multiple cells and waste types). In some cases, particular coupled processes may be beneficial to long-term cover performance for some waste types. In other cases, some processes may not. Nevertheless, a better understanding of coupled processes and how ET covers may change over time can help in determining processes that should be considered or perhaps even enhanced to meet the overall performance criteria for the waste disposal systems. 


\section{ACKNOWLEDGEMENTS}

Thanks are extended to Susan Edwards and Robert Jones of the Desert Research Institute for assistance in researching the history of analog sites and with interpreting the archeological resources near Analog Site 3. Mary Cablk of DRI provided insight on burrowing characteristics of animals. Julianne Miller, David Gillespie, John Goreham, and Darren Meadows assisted with fieldwork. Stuart Rawlinson of Bechtel Nevada provided additional information on interpreting the ages of analog sites and assisted with selection of Analog Sites 1 and 2. Mark Hooten of Neptune and Company, Inc., helped with vegetation transects and provided insights on burrowing insects at Analog Sites 1 and 2. The Waste Management Division, U.S. Department of Energy, National Nuclear Security Administration Nevada Site Office and Office of Science and Technology Development at Department of Energy Headquarters provided funding for this project under Contract No. DE-AC52-00NV13609. 


\section{CONTENTS}



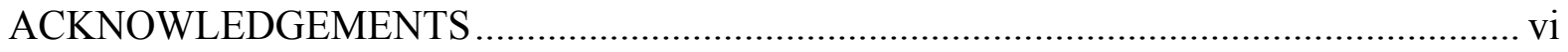

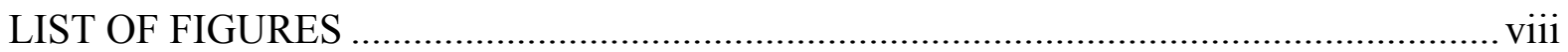

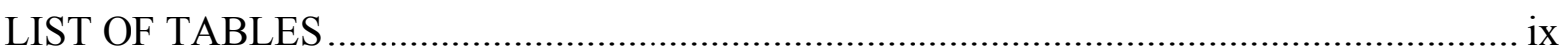

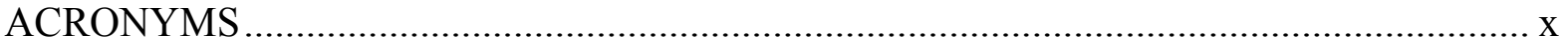

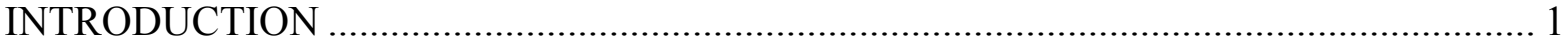



PERFORMANCE OBJECTIVES OF ET COVERS BEING EVALUATED .......................... 2

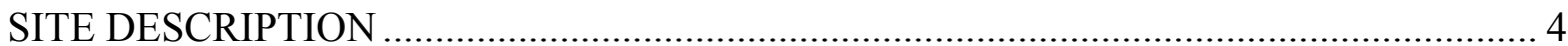

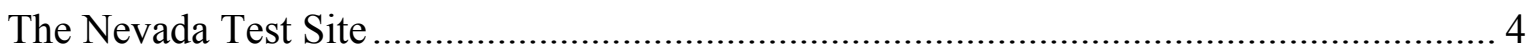

Attributes of the NTS as a Regional Waste Disposal Site .................................................... 4

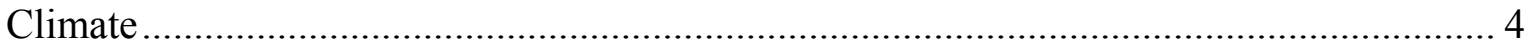

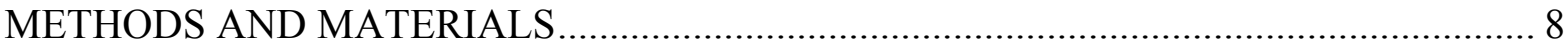

Criteria for Selection of Analog Sites ........................................................................... 8

Limitations of the Primary Analog Sites ................................................................. 14

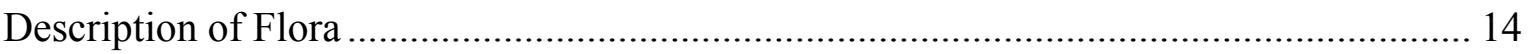

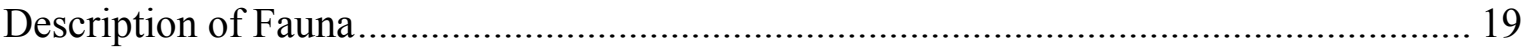

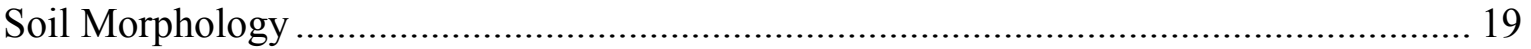

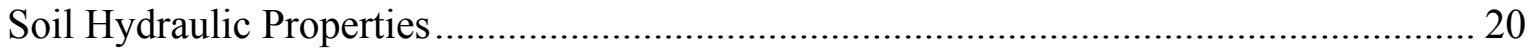

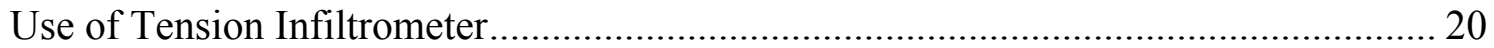

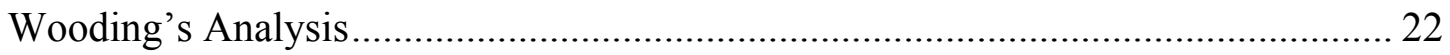

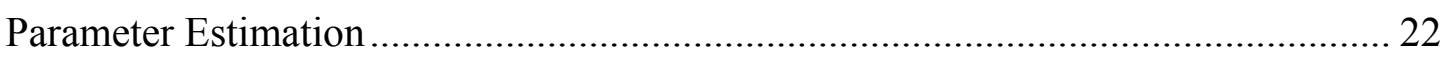

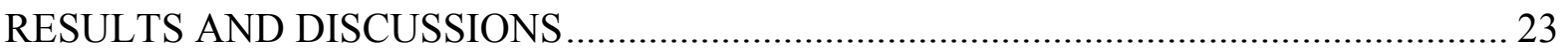

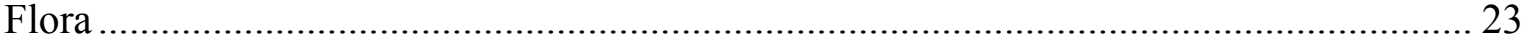

Fauna

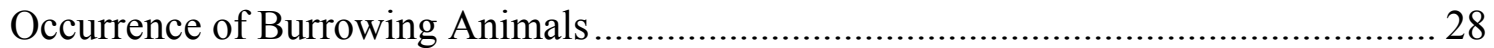

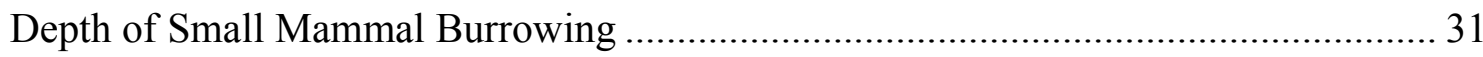

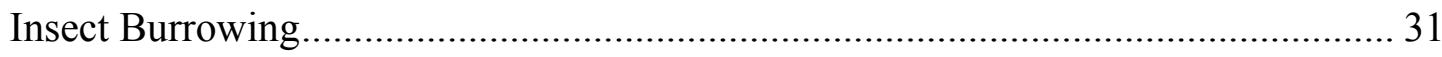

Soil Morphology ………………………………………………………………… 31



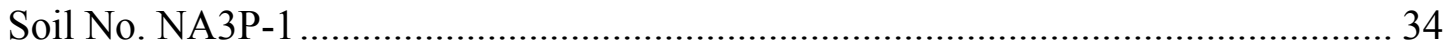

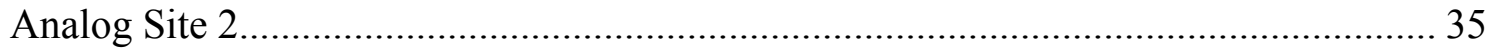




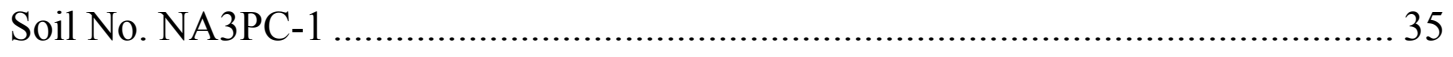

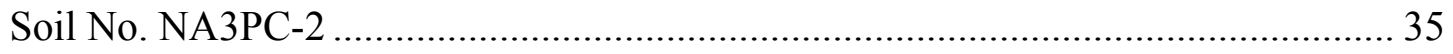

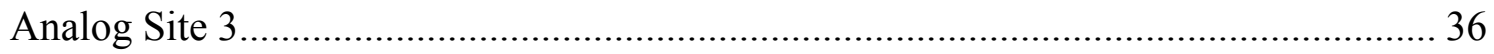

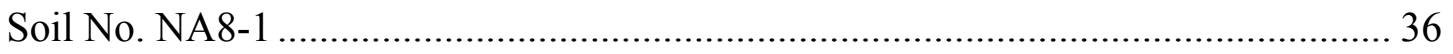

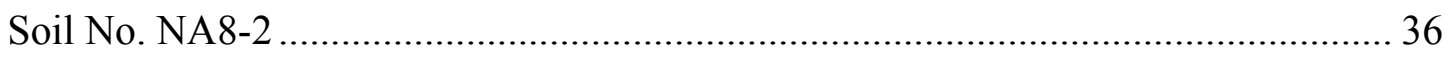

Soil Hydraulic Properties ............................................................................................ 37

CONCLUSIONS.................................................................................................. 43

Deposition of Fines and Development of Soil Structure ................................................... 43

Progressive Decrease in Infiltration and Saturated Hydraulic Conductivity ...................... 43

Development of Desert Pavements on Covers................................................................ 44

Degree of Vegetation Cover and Desert Pavement Formation........................................... 44

Development of 'Fertile Islands' on Covers ................................................................. 44

Species Composition for Initial Vegetation Establishment on ET Covers .......................... 47

ADDITIONAL RESEARCH......................................................................................... 47

Impacts of Burrowing Insects ...................................................................................... 48

Evaluating Subsidence Assumptions ……………………....................................... 48

Adaptive Management for Cover Design at the NTS ........................................................ 49

Frenchman Flat Analog Site ......................................................................................... 49

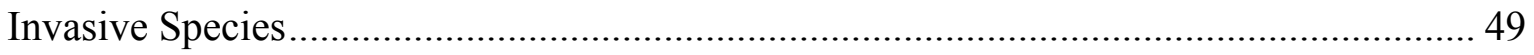

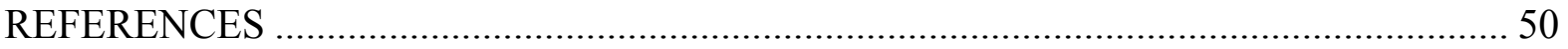

\section{LIST OF FIGURES}

1. The Nevada Test Site (NTS), where the primary analog sites are located, is in a transition zone between the Mojave and Great Basin deserts........................................... 3

2. The NTS, located $105 \mathrm{~km}$ northwest of Las Vegas, Nevada............................................ 5

3. The wind rose developed from data at MEDA Station 3 illustrates the strong bimodal distribution of dominant wind directions in Yucca Flat. ..................................... 7

4. View of primary Analog Site 1, the construction pad, showing establishment of

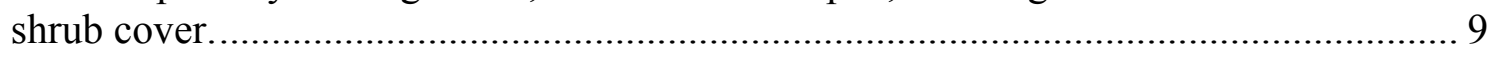

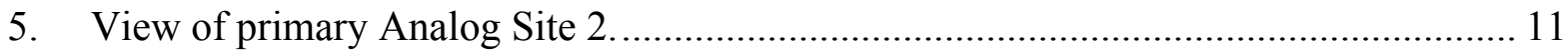

6. View of primary Analog Site 3 in Area 8 of the NTS .................................................. 12

7. View of Analog Site 4 following a rainfall event hours earlier...................................... 13

8. Perennial plant distribution within two perpendicular belt transects $(5 \times 50 \mathrm{~m}$ and 5 x $20 \mathrm{~m}$ ) on Analog Site 1 (30 years old)............................................................. 15 
9. Perennial plant distribution with a $10 \times 50 \mathrm{~m}$ belt transect on Analog Site $2(1,000$ to 2,000 years old).

10. Perennial plant distribution with a 10 x $50 \mathrm{~m}$ belt transect on Analog Site $3(7,500$ to 12,000 years old).

11. Perennial plant distribution with a $10 \times 50 \mathrm{~m}$ belt transect on Analog Site $4(125,000$ years old)

12. Winter annual individual species densities for undercanopy and intercanopy microsites within four analog sites with surfaces ranging from 30 to 125,000 years old. 26

13. The influence of undercanopy and intercanopy microsites on total winter annual plant densities within four analog sites with surfaces ranging from 30 to 125,000 years old. .... 28

14. The influence of undercanopy and intercanopy microsites on animal burrow densities within four sites with surfaces ranging from 30 to 125,000 years old.

15. The relationships between animal burrow densities, winter annual plant densities and live and dead perennial plant cover among four analog sites with surfaces ranging from 30 to 125,000 years old.

16. Graphs showing representative observed and simulated responses from tension infiltrometer and HYDRUS-2D model, respectively, for Site 4, intercanopy (A) and undercanopy (B) sites.

17. Geometric means of Ksat using semi-empirical (A) (Wooding's) and parameter estimation (B) (HYDRUS-2D) methods, for intercanopies and undercanopies.

Regression models are shown as solid lines.

18. Locally, during the winter of calendar year 2002 to 2003, intercanopy burrowing by small mammals was extensive. 46

19. Secondary Analog Site A is on the floor of Yucca Flat south of the Area 3 RWMS... 48

\section{LIST OF TABLES}

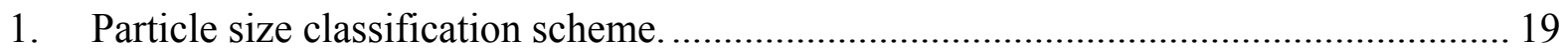

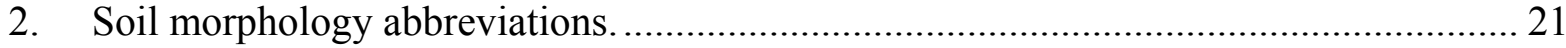

3. Mean + standard error for live and dead perennial plant cover in native northern Mojave Desert plant communities at four sites of varying age located at the Nevada Test Site.

4. Diversity and percent cover by native perennial plant species in four northern Mojave Desert plant communities on variable-age surfaces located at the Nevada Test Site..... 25

5. Winter annual diversity and density (plants $/ \mathrm{m}^{2}$ ) in four northern Mojave Desert plant communities on variable-age surfaces located at the Nevada Test Site. 27

6. Summary of soil morphology. 32

7. Summary of measured soil properties... 34 
8. Breakdown of the location and number of field tests conducted for hydraulic property analyses...

9. Average \pm standard deviation for textural components of material sampled at intercanopy and undercanopy areas. 38

10. Results of field analyses of hydraulic properties at the four analog sites. Ksat and alpha parameters are represented as geometric mean.

\section{ACRONYMS}

$\begin{array}{ll}\text { bgs } & \text { below ground surface } \\ \text { BP } & \text { before present } \\ \text { DRI } & \text { Desert Research Institute } \\ \text { DOE } & \text { U.S. Department of Energy } \\ \text { ET } & \text { evapotranspiration } \\ \text { LLW } & \text { low-level waste } \\ \text { LTS } & \text { long-term stewardship } \\ \text { MEDA } & \text { Meteorological Data Acquisition } \\ \text { NNSA } & \text { National Nuclear Security Administration } \\ \text { NRCS } & \text { Natural Resources Conservation Service } \\ \text { NSO } & \text { Nevada Site Office } \\ \text { NTS } & \text { Nevada Test Site } \\ \text { OSL } & \text { Optical Stimulated Luminescence } \\ \text { RWMS } & \text { Radioactive Waste Management Site } \\ \text { SNL } & \text { Sandia National Laboratories } \\ \text { TI } & \text { tension infiltrometer } \\ \text { USDA } & \text { U.S. Department of Agriculture }\end{array}$




\section{INTRODUCTION}

Vegetated, evapotranspiration or "ET" covers are gaining acceptance at arid and semi-arid sites for waste site closure based on water-balance and related studies being conducted at the Nevada Test Site (NTS), Sandia National Laboratories (SNL) (Dwyer, 1997), and Pacific Northwest National Laboratory at Hanford (Gee et al., 1997), as well as other locations. In addition, at more than a dozen sites across the United States through the U.S. Environmental Protection Agency's Alternative Cover Assessment Program (http://www.dri.edu/Projects/EPA/boston-brochure2.html), ET components are being incorporated into alternative cover designs (Benson et al., 2000). Other federal facilities, such as the Edwards Air Force Base in California, are developing site-wide strategies for closure of waste disposal sites using ET covers. The principle behind this closure technology is that soil evaporation and plant transpiration remove water that infiltrates into layers of native soil that covers the waste. Evapotranspiration covers are a significant departure from traditional closure cover designs, which feature geotechnical layers that restrict infiltration of water through either a capillary break or reduction of permeability, or both. Rather than attempting to restrict infiltration of water, the ET cover allows water to infiltrate into the soil where natural processes then remove the water. At the NTS, monolayer ET covers have been selected as the baseline technologies for closure of landfills or cells being used for the disposal of low-level radioactive waste (LLW), mixed LLW, as well as areas where transuranic (TRU) and mixed TRU waste have been disposed of (Bechtel Nevada, 2001).

However, vegetated ET covers, as well as other types of covers, cannot be viewed as static features. Covers will be subject to natural processes of change, the same as any alluvial/colluvial landform, particularly after the period when cover maintenance ends. These changes, and their subsequent impact on long-term cover performance, are difficult to capture in performance modeling and in many cases are poorly understood. Among the most significant shortcomings is our understanding of the relationships between soil water dynamics, soil morphologic development, and plant ecology in arid regions (McDonald, 2002). At the NTS, covers for LLW must be designed to have a "reasonable expectation" of limiting potential doses to the public for over a 1,000-year period (Phifer, 2002). In addition, TRU and mixed TRU waste are disposed of in the Greater Confinement Disposal boreholes and one shallow land-disposal unit in the Area 5 Radioactive Waste Management Site (RWMS). Accordingly, closure systems for these wastes could be subject to a 10,000-performance period (Cochran et al., 2001). If the 10,000-year Holocene period is representative of future conditions, then the potential for change to covers for these waste sites is significant.

\section{PROJECT OBJECTIVES}

To supplement traditional approaches of cover design and performance prediction, a series of "analog" sites was studied to serve as predictive tools for how an ET cover could evolve over 1,000-year and 10,000-year periods at the NTS. By understanding how a cover could change over time, modifications could be made to ET cover design, maintenance, and monitoring in the near term that could improve its long-term performance. However, whether particular coupled processes and the changes they cause to ET covers over time is beneficial to the waste disposal system depends on the types of waste, potential pathways of concern, and the overall closure strategy, particularly when different waste types are disposed of in 
close proximity. An important assumption in selecting a temporal sequence of analog sites is that a look back in times provides evidence of how similar sites and features may evolve in the future.

The most widespread use of ET covers is in arid and semi-arid regions, such as the NTS, where environmental processes could modify the cover over time. These processes could include the following:

- Erosion, eolian deposition, and other surface modifications

- Pedogenic development

- Vegetation growth and succession

- Biointrusion from plants and animals

- Subsidence

There is often a tendency to view such processes individually; however, many are linked, or "coupled," to each other, sometimes with potentially competing impacts on the performance of the cover for containing or isolating waste. As an example, work in the Mojave National Preserve in California suggests that significant eolian deposition of fine particles can occur, even on surfaces as young as 500 to 1,000 years old (McDonald et al., 2002). This can have a beneficial impact of reducing infiltration potential and enhancing the cover performance. However, accumulation of these same fines could promote biointrusion by small mammals, normally a process viewed as having a detrimental impact on cover performance. The reduction of infiltration potential and promotion of biointrusion are linked to eolian deposition and (in this case) time. Yet, the strengths of these links are not well understood because the data on ecosystem-wide responses are generally unavailable.

The goal of this project was to better characterize the coupled processes that will affect vegetated, monolayer ET covers in the northern Mojave/southern Great Basin deserts where the NTS is located, focusing on the 1,000-year performance period pursuant to the U.S. Department of Energy (DOE) Order 435.1, and a 10,000-year performance period pursuant to Title 40 CFR 191. Four "primary" analog sites on the NTS were studied in detail. Additional observations and measurements were made at secondary analog sites, including locations in other regions of the southwestern U.S., to better understand particular processes (Figure 1).

\section{PERFORMANCE OBJECTIVES OF ET COVERS BEING EVALUATED}

The objectives of this study were to evaluate the impacts of potential environmental change on ET covers. While the cover does not represent the entire waste disposal system, the use of ET covers in place is a significant change in strategies for waste disposal and isolation. Primary performance objectives of monolayer ET covers identified in Section 2.1.2 of the Integrated Closure and Monitoring Plan (Bechtel Nevada, 2001) for the NTS that were evaluated in this study include the following:

- That the cover provides long-term minimization of migration of liquids through the landfill.

- That it functions with minimum maintenance.

- That it promotes drainage and that erosion or abrasion of the cover be minimized. 
The performance objective that the ET cover "accommodate setting and subsidence..." to maintain cover integrity is discussed under "Additional Research."

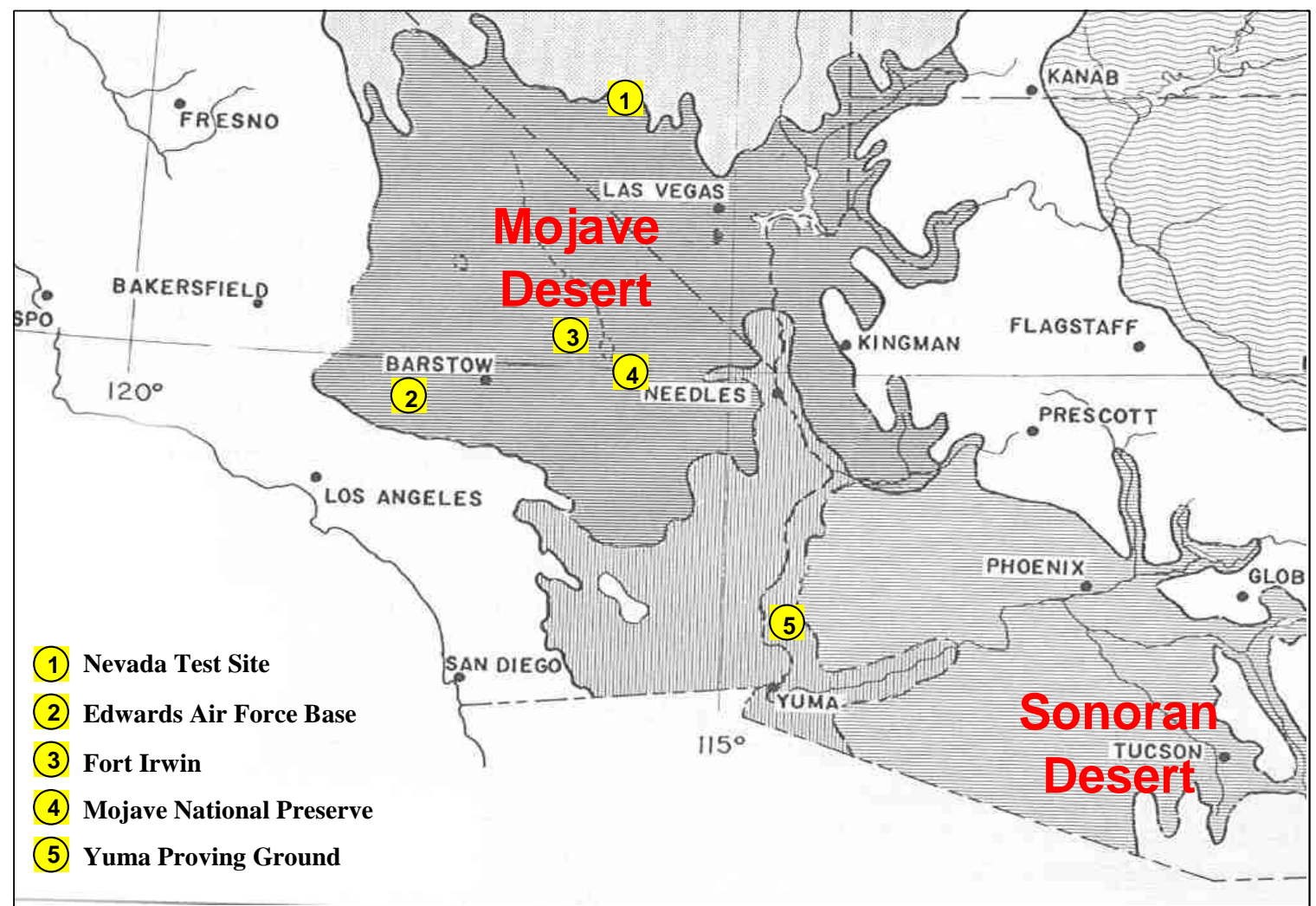

Figure 1. The Nevada Test Site, where the primary analog sites are located, is in a transition zone between the Mojave and Great Basin deserts. Other locations discussed include Edwards Air Force Base; the National Training Center, Fort Irwin; and the Providence Mountains in the Mojave National Preserve, all in California; as well as the U.S. Army Yuma Proving Ground, Arizona.

This study also addresses some of the DOE National Nuclear Security Administration Nevada Site Office (NNSA/NSO) technology needs for monolayer, arid-site closure covers including the need for "additional information on long-term evolution (100 to 1,000 years) of these covers as land-form features that change because of natural pedogenic, biotic, and climatic processes..., and functional performance requirements of 'survivability for limiting infiltration' and 'effective high evapotranspiration ability"' (DOE, 2003).

As previously discussed, what cannot be evaluated at this time is the impact of the coupled processes studied on all potential pathways of concern. The NNSA/NSO Waste Management Program is in the process of evaluating the feasibility of new waste streams (e.g., those that produce high radon flux) and is currently considering multiple closure strategies (e.g., many individual cells closured with ET covers, as opposed to larger cover systems that would enclose multiple cells and waste types). Nevertheless, a better understanding of coupled processes and how ET covers may change over time can help in 
determining processes that should be considered or perhaps even enhanced to meet the overall performance criteria for the waste disposal systems.

\section{SITE DESCRIPTION}

\section{The Nevada Test Site}

The NTS, managed by the DOE NNSA/NSO, is located in Nye County in southern Nevada (Figure 2). Its southernmost point is about 105 kilometers $(\mathrm{km})(65$ miles) northwest of Las Vegas, Nevada. The NTS encompasses approximately 3,561 square km (1,375 square miles) of the Basin and Range physiographic province. Elevations range from about 1,067 meters $(\mathrm{m})(3,500 \mathrm{ft})$ on the lower basin floors to about 2,285 m (7,500 ft) on Rainier Mesa on the northern end of the site. Yucca Flat is a structurally closed basin in the northeast quadrant of the NTS, encompassing an area of about $780 \mathrm{~km}^{2}\left(300 \mathrm{mi}^{2}\right)$. The Yucca Flat playa, normally dry, is on the southern end of the basin.

Two areas on the NTS are used for shallow land disposal of LLW and mixed LLW from approved generators across the U.S.: the Area 5 RWMS in Frenchman Flat and, the Area 3 RWMS in central Yucca Flat. However, there are subtle differences between the climate and plant communities found in Frenchman Flat and those in Yucca Flat, since the central portion of the NTS is in a transition zone between the Mojave and Great Basin deserts, or ecoregions (Ostler et al., 2000). Consequently, the recently constructed U-3axbl ET cover in the Area 3 RWMS (Levitt and Fitzmaurice, 2001) serves as the primary baseline for comparison with the four primary analog sites selected for this study because it is also located in the Yucca Flat basin.

\section{Attributes of the NTS as a Regional Waste Disposal Site}

The NTS is one of two regional sites used for shallow land disposal of LLW generated by DOE and Department of Defense (DoD) activities in the U.S. Among the attributes of the NTS site are:

- The combination of low annual precipitation (ranging between 7.6 and $25.4 \mathrm{~cm}$ [3.0 and 10.0 in]) and high evapotranspiration rates (Bechtel Nevada, 2001).

- The depth to groundwater (over $600 \mathrm{~m}$ [approximately 2,000 ft] in Yucca Flat).

- Evidence from stable isotope compositions of soil pore water (Tyler et al., 1996) that evaporation is the dominant process between 3 and $49 \mathrm{~m}(10$ to $160 \mathrm{ft})$ depth in Yucca Flat, and 3 and $49 \mathrm{~m}$ (3 to $130 \mathrm{ft}$ ) in Frenchman Flat.

- Conservative modeling by Levitt et al. (1998) that travel times under present climate conditions from the root zone to groundwater in Yucca Flat exceeds 500,000 years assuming no upward flux.

In short, what recharge there is to the groundwater in Frenchman Flat and Yucca Flat is limited to areas along mountain fronts, and that in the vicinity of the Area 3 and Area 5 RWMS, there is no areally distributed groundwater recharge (Shott et al., 1997; Shott et al., 1998).

\section{Climate}

Yucca Flat has an average annual precipitation of $15.7 \mathrm{~cm}(6.2 \mathrm{in})$ based on a 1960 to 2003 summary of data from the Meteorological Data Acquisition (MEDA) Station 3 in Yucca Flat operated by the Air Resources Laboratory, National Oceanic and Atmospheric Administration (http://www.sord.nv.doe.gov/home_climate_MEDA.htm). This annual 


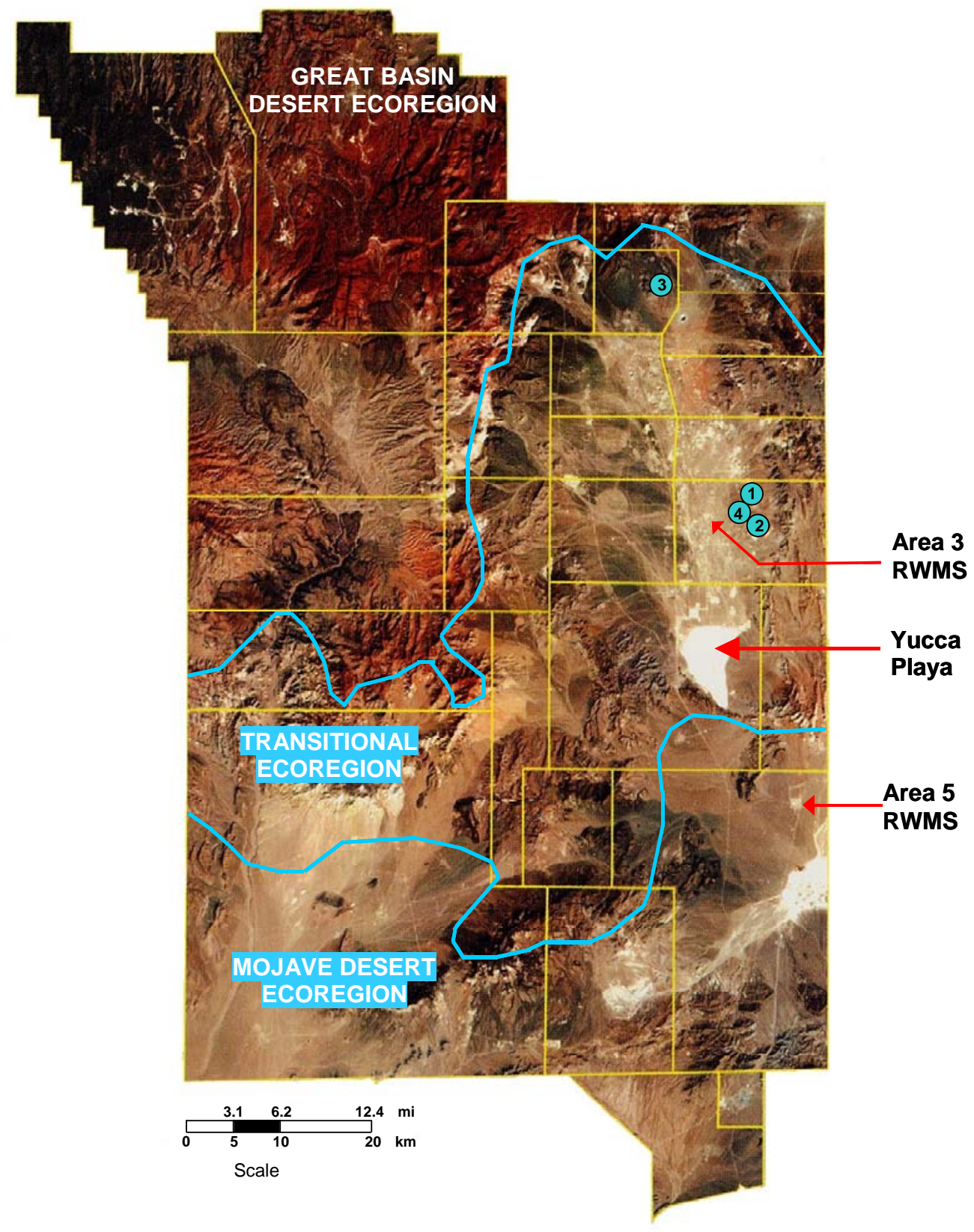

Figure 2. The NTS, located $105 \mathrm{~km}$ northwest of Las Vegas, Nevada. Primary Analog Sites 1, 2, and 4 are located in Area 3, as is the Area 3 RWMS. Primary Analog Site 3 is located in the southern part of Area 8. The Area 5 RWMS is located in Frenchman Flat. Other important features include the Yucca Flat playa at the southern end of the Yucca Flat basin. The primary analog sites are all located in a transition zone between the Mojave Desert and Great Basin desert ecoregions on the NTS. 
precipitation is similar to the amounts measured at other low-elevation areas of the NTS. For comparison, annual precipitation at Well 5B in Frenchman Flat near the Area 5 RWMS is $12.7 \mathrm{~cm}$ (5.0 in) based on a 30-year record (Shott et al., 1995). However, typical of other parts of the Mojave and southern Great Basin deserts, there is strong variation from year to year. The annual values have ranged from a low of $3.8 \mathrm{~cm}(1.5 \mathrm{in})$ in 2002 to $37.3 \mathrm{~cm}(14.7$ in) in 1998. That the lowest annual precipitation in this 43-year record occurred in 2002 is testament to the severity of the regional drought that has been occurring during this study. The 1998 high in annual precipitation, and the $37.8 \mathrm{~cm}$ (13.7 in) and $27.7 \mathrm{~cm}$ (10.9 in) that occurred in 1982 and 1983, respectively, were both associated with El Nino events. On average, approximately 57 percent of annual precipitation occurs between November and March. Slightly more precipitation falls in July and August than the remaining months, although on average, precipitation during these months represents only 17.4 percent of annual precipitation. In short, the Mojave Desert is the most arid ecosystem in North America and has the most unpredictable precipitation, an abiotic factor that can inhibit or impair the establishment of perennial plants for an ET cover (Rundel and Gibson, 1996).

As discussed later, eolian deposition of fines (silt and clay) is probably one of the most important processes that will affect cover development on the NTS. The distribution of wind in Yucca Flat is strongly bimodal in direction throughout the year. Wind data presented herein are summarized from a 1994 to 2001 summary of wind speeds and directions measured at the MEDA Station 3 in Yucca Flat (Figure 3). The preponderance of wind is from the north-northeast to northwest and south to southwest. On an annual basis, 43.7 percent of the wind is from the northwest to north-northeast quartiles, 27.4 percent from the south to southwest. However, imprinted on the annual trends are two strong temporal trends. From October through April, winds are dominantly out of the north to northwest, often associated with low-pressure cells that form in the Great Basin. This trend is most pronounced in November and December, when 43.3 percent and 42.1 percent of the wind are from these quartiles, respectively. Between May and August, winds are dominantly out of the south-southwest, and are most pronounced in July when 39.7 percent of the wind is out of these quartiles. September is a transitional month in wind directions. In terms of soil-forming processes on covers, particularly when winds are from the south, and with the Yucca Flat playa and whole of southern Yucca Flat serving as a significant source of fine-grained particulates, eolian deposition has contributed to well-developed vesicular horizons at the older primary analog sites.

For Yucca Flat, temperature data from 1983 to 2001 for MEDA Station 3 indicate an average monthly high of $22.5^{\circ} \mathrm{C}\left(72.5^{\circ} \mathrm{F}\right)$, and a low of $4.2^{\circ} \mathrm{C}\left(39.6^{\circ} \mathrm{F}\right)$. December and January have historically been the coolest months, with average highs of $11.3^{\circ} \mathrm{C}\left(52.4^{\circ} \mathrm{F}\right)$ and $11.2^{\circ} \mathrm{C}$ $\left(52.1^{\circ} \mathrm{F}\right)$, and lows of $-5.4^{\circ} \mathrm{C}\left(22.3^{\circ} \mathrm{F}\right)$ and $-4.3^{\circ} \mathrm{C}\left(24.3^{\circ} \mathrm{F}\right)$. July has on average been the warmest month, with average maximum temperatures of $35^{\circ} \mathrm{C}\left(95^{\circ} \mathrm{F}\right)$ and minimum temperatures of $14.6^{\circ} \mathrm{C}\left(58.2^{\circ} \mathrm{F}\right)$. The lowest recorded temperature was $-21.7^{\circ} \mathrm{C}\left(-7^{\circ} \mathrm{F}\right)$ in December 1990 . The highest temperature during this period of record was $43.3^{\circ} \mathrm{C}\left(110^{\circ} \mathrm{F}\right)$ in July 1998. In general, high temperatures and low humidity characterize summers here and elsewhere in the Mojave Desert. 


\section{Wind Speeds}

50 - $99 \mathrm{mph}$

80 - $159 \mathrm{~km} / \mathrm{hr}$

40 - $49 \mathrm{mph}$

$64-79 \mathrm{~km} / \mathrm{hr}$

30 - $39 \mathrm{mph}$

$48-63 \mathrm{~km} / \mathrm{hr}$

20 - $29 \mathrm{mph}$

32 - $47 \mathrm{~km} / \mathrm{hr}$

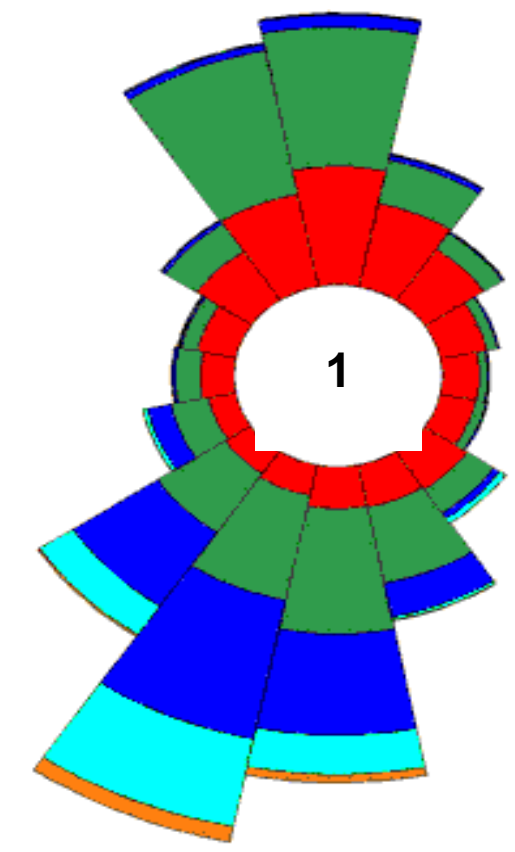

July

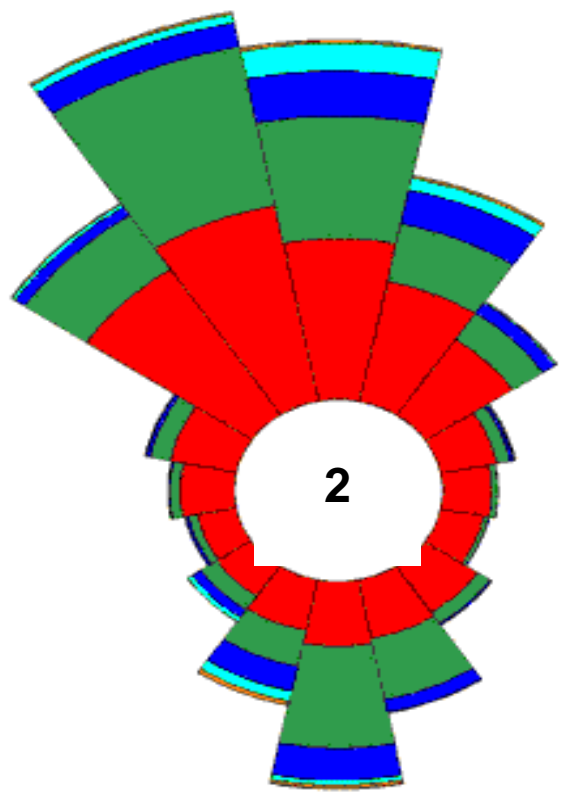

November

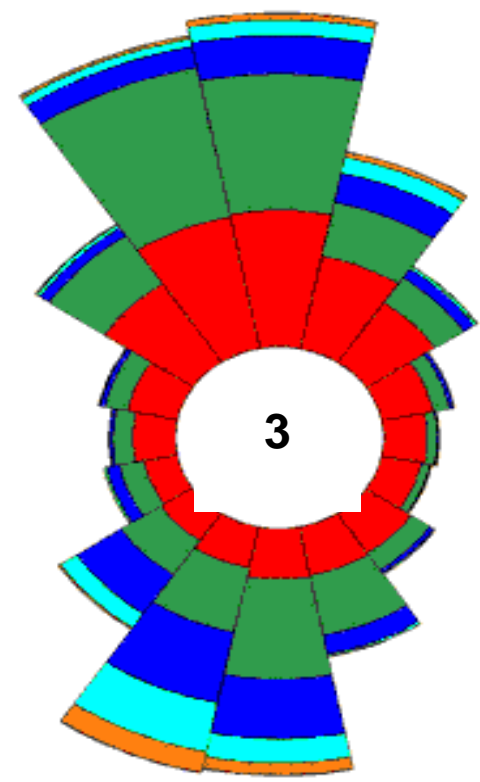

Annual

$-9 \mathrm{mph}$
$7-14 \mathrm{~km} / \mathrm{hr}$

$1-4 \mathrm{mph}$

$2-6 \mathrm{~km} / \mathrm{hr}$

Figure 3. The wind rose developed from data at MEDA Station 3 illustrates the strong bimodal distribution of dominant wind directions in Yucca Flat. The number in the center of each wind rose is the percent cal. 


\section{METHODS AND MATERIALS}

\section{Criteria for Selection of Analog Sites}

As previously discussed, the primary analog sites are within the Yucca Flat basin, a transition zone on the NTS between the Mojave and Great Basin deserts. The primary analog sites were selected based on the following types of criteria (Shafer et al., 2002):

- They represent a chronology of surface and subsurface ET cover conditions and properties covering the early post-institutional control period (Site 1), to the end of a 1,000-performance period (Site 2), through a 10,000-year performance period (Site 3). Site 4, estimated to be mid-Pleistocene in age, is adjacent to Site 1 and was studied as a point of comparison for vegetation establishment and soil hydraulic properties to the youngest primary analog site.

- Surface gradients were low, eliminating the need to consider such processes as sheet wash that a newly constructed ET cover would be designed not to experience.

- There was evidence that the sites had been isolated from any recent alluvial or colluvial deposition, or erosion processes.

- Anthropomorphic impacts were minimal, or if present, their effects could be clearly distinguished from those caused by natural processes.

- There were methods for determining or estimating when the surface or landform was created or abandoned so that the length of time over which features have developed could be estimated.

The age estimate for the Site 1 surface is based on historical data. The age of the Site 3 surface is based on geomorphic evidence and an unusual archeological assemblage. For Sites 2 and 4, age control is based on geomorphic criteria and some conventional age measurements developed by Bechtel Nevada (1998). Nomenclature for geomorphic surfaces in the area were first developed for the proposed Yucca Mountain Geological Repository, and then applied to Frenchman Flat around the Area 5 RWMS. Criteria for different age geomorphic surfaces were developed and used along with remote imagery for mapping surfaces in Yucca Flat around the Area 3 RWMS. In addition, a charcoal sample was collected and a series of optical stimulated luminescence (OSL) analysis of sediments were obtained in a trench constructed near the Area 3 RWMS. Carbon-14 analysis of the charcoal sample resulted in a conventional age of 10,530 years before present (BP). An OSL sample from sediments stratigraphically higher than the charcoal sample provides an age of approximately 10,000 years BP (Bechtel Nevada, 1999). These provide maximum age control for Analog Site 2, although geomorphic criteria and the degree of soil developed suggest the site is considerably younger. The primary analog sites are described and numbered in order from youngest to oldest.

Site 1 (UTM Coordinates 0589957E, 4102536N, elevation 1,274 m [4,180 ft]) was a cut-and-fill equipment storage and staging area constructed for underground nuclear tests conducted in 1971 and 1972 (Figure 4). It is believed to have been abandoned for about 30 years (i.e., since 1973) and was selected to study how an ET cover could change in the first few decades following the cessation of cover maintenance during a 100-year 
post-institutional control period (Bechtel Nevada, 2001). Engineering records indicate that the area was graded flat, and then brought to near grade with the adjacent powerline access road using alluvial borrow material from a nearby source. A thin, pea-gravel cover (approximately $0.64 \mathrm{~cm}[0.25 \mathrm{in}]$ thick) was also placed on the surface to help stabilize it, particularly if it became wet.
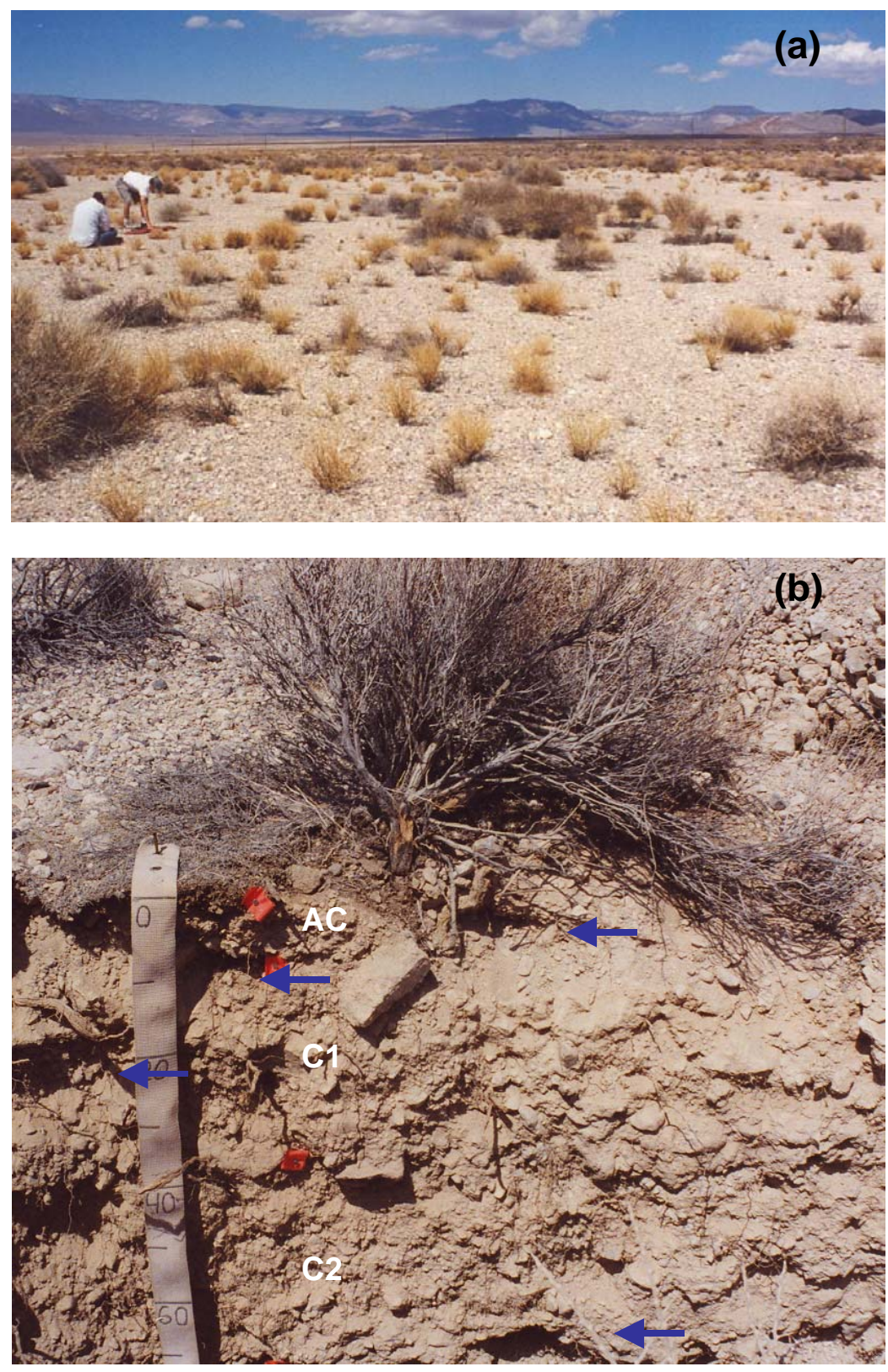

Figure 4. View of primary Analog Site 1, the construction pad, showing establishment of shrub cover (a). Soil profile NA3P-1 below Ephedra nevadensis canopy (b). The red flagging marks depth of soil horizon boundaries. The arrows point to animal burrows. The tape measure shows depth in $\mathrm{cm}$. 
Successful natural recruitment and establishment of native perennial species has occurred during the last 30 years (to be discussed later). Some of the perennial shrub species include Mormon tea (Ephedra nevadensis), two rabbitbrush species (Chrysothamnus nauseosus and C. viscidiflorus), shadscale (Atriplex confertifolia), cheesbush (Hymenochlea salsola), and desert alyssum (Lepidium fremontii). Other native species that have recruited naturally include a perennial grass (Achnatherum hymenoides), perennial forbs (Sphaeralcea ambigua and Stephanomeria pauciflora) and 12 species of winter annuals. Four exotic annuals have also become established on Site 1: halogeton (Halogeton glomeratus), Russian thistle (Salsola iberica), cheatgrass (Bromus tectorum), and red brome (B. madritensis).

Site 2 (UTM Coordinates 0589812E, 4100805N, elevation 1,261 $\mathrm{m}[4,137 \mathrm{ft}]$ ) is an abandoned late Holocene alluvial/distal fan surface on the east side of Yucca Flat (Figure 5). Although shallow, intermittent channels bound the area today, the presence of mature Joshua trees (Yucca brevifolia) indicates that the surface has been abandoned with respect to runoff in the area. This site was selected to represent analog conditions at the end of a 1,000-yearperformance period for a cover. The dominant native perennial shrubs on Site 2 include fourwinged saltbush (Atriplex canescens), Mormon tea (Ephedra nevadensis), box thorn (Lyciuim andersonii), cheesbush (Hymenochlea salsola), shadscale (A. confertifolia), spiney hopsage (Grayia spinosa) and winterfat (Krascheninnikovia lanata). Indian ricegrass (Achnatherum hymenoides) has high density, but low total cover. An endemic forb, nodding four-o'clock (Mirabilis pudica), is also relatively common. Maximum winter annual diversity among the four study sites of 23 species was also observed for Site 2.

No absolute age control was obtained for the site. However, based on geomorphic criteria in Bechtel Nevada (1998) and review of the site by one of its authors (S. Rawlinson, personal communication, 2001), the surface is thought to be an S6 surface, placing its age between approximately 1,000 and 2,000 years BP. Features of Site 2 consistent with criteria for S6 surfaces include its low position vertically above active alluvial channels and the lack of abandoned alluvial channels on the surface; incipient desert pavement development over small areas; and the lack of clast varnish or rubification. The site also has a well-established vegetative cover, active bioturbation, and cryptobiotic crust is present.

Site 3 (UTM Coordinates 0583694E, 4118912N, elevation 1,463 m [4,800 ft]) is located in Area 8 on the north end of Yucca Flat. The site is on a now inactive alluvial/colluvial fan lobe that extends south from Rainier Mesa in the vicinity of Oak Springs and the Climax Mine (Figure 6). The top of the fan slopes less than four degrees to the southeast. Previous geomorphic mapping by Bechtel Nevada identified the fan as early Pleistocene in age (Bechtel Nevada, 1999). While this is still likely an accurate assessment of the age of the geomorphic feature, analysis of two soil trenches constructed at the site indicates more recent deposition on the surface of the fan and the development of a younger soil overlying a paleosol.

A minimum age control for the surface of Site 3 is provided by the occurrence of a distinct and relatively unusual assemblage of cultural resource artifacts that are evidence of a temporary camp having been established in the early Holocene or late Pleistocene. The site (\#26NY11673) was discovered as part of a cultural resources reconnaissance for an access road to a new groundwater characterization well (ER-8-1) (Jones, 2002). Artifacts are obsidian, basalt, and silicified volcanic tools and debitage as well as red/brown welded tuff groundstone. It is estimated that there are between 600 and 800 artifacts at the site. 

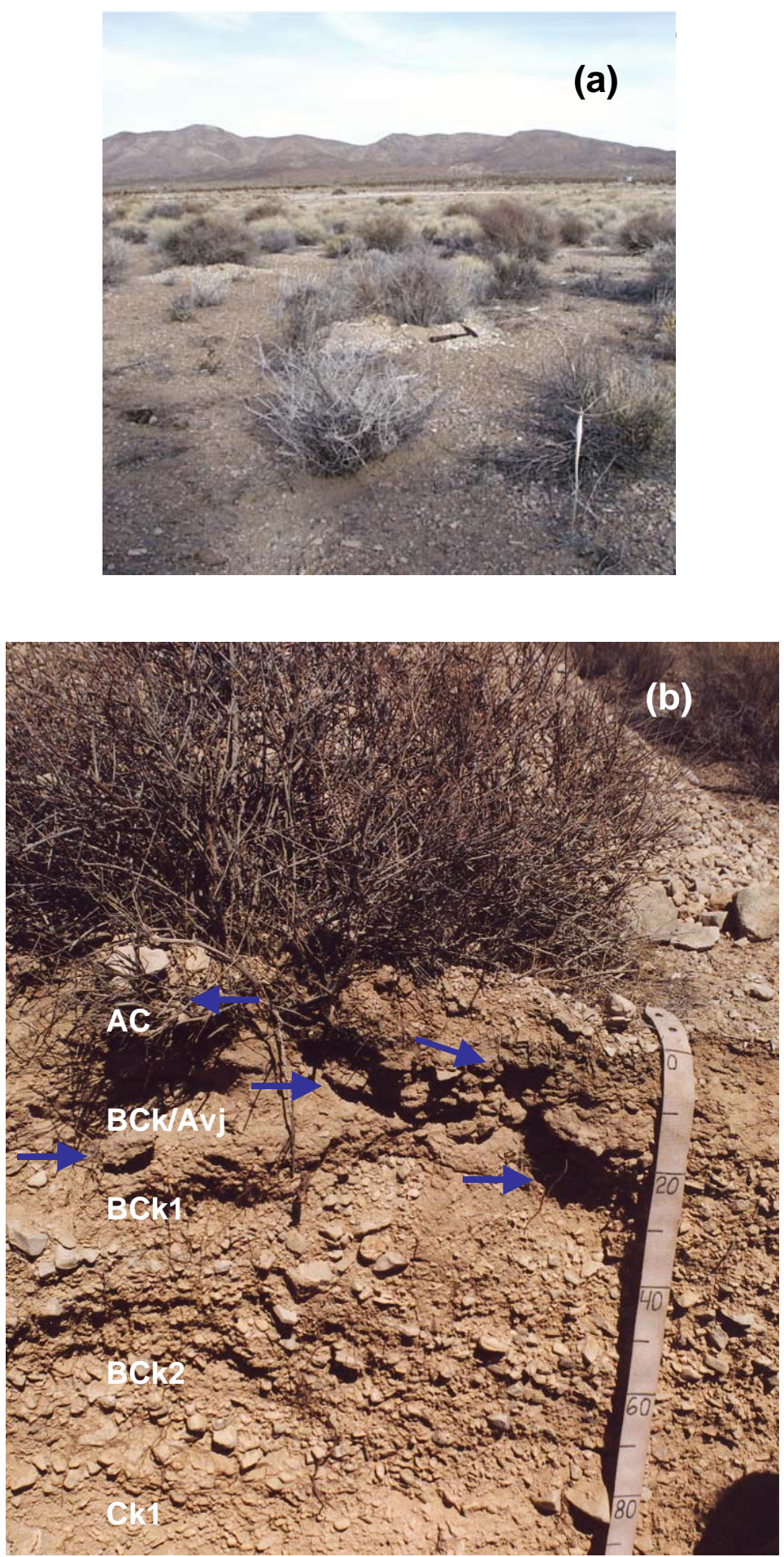

Figure 5. View of primary Analog Site 2 (a). The soil profile NA3PC-1 is below an Ephedra nevadensis canopy (b). The arrows point to animal burrows. The tape measure shows depth in $\mathrm{cm}$. 


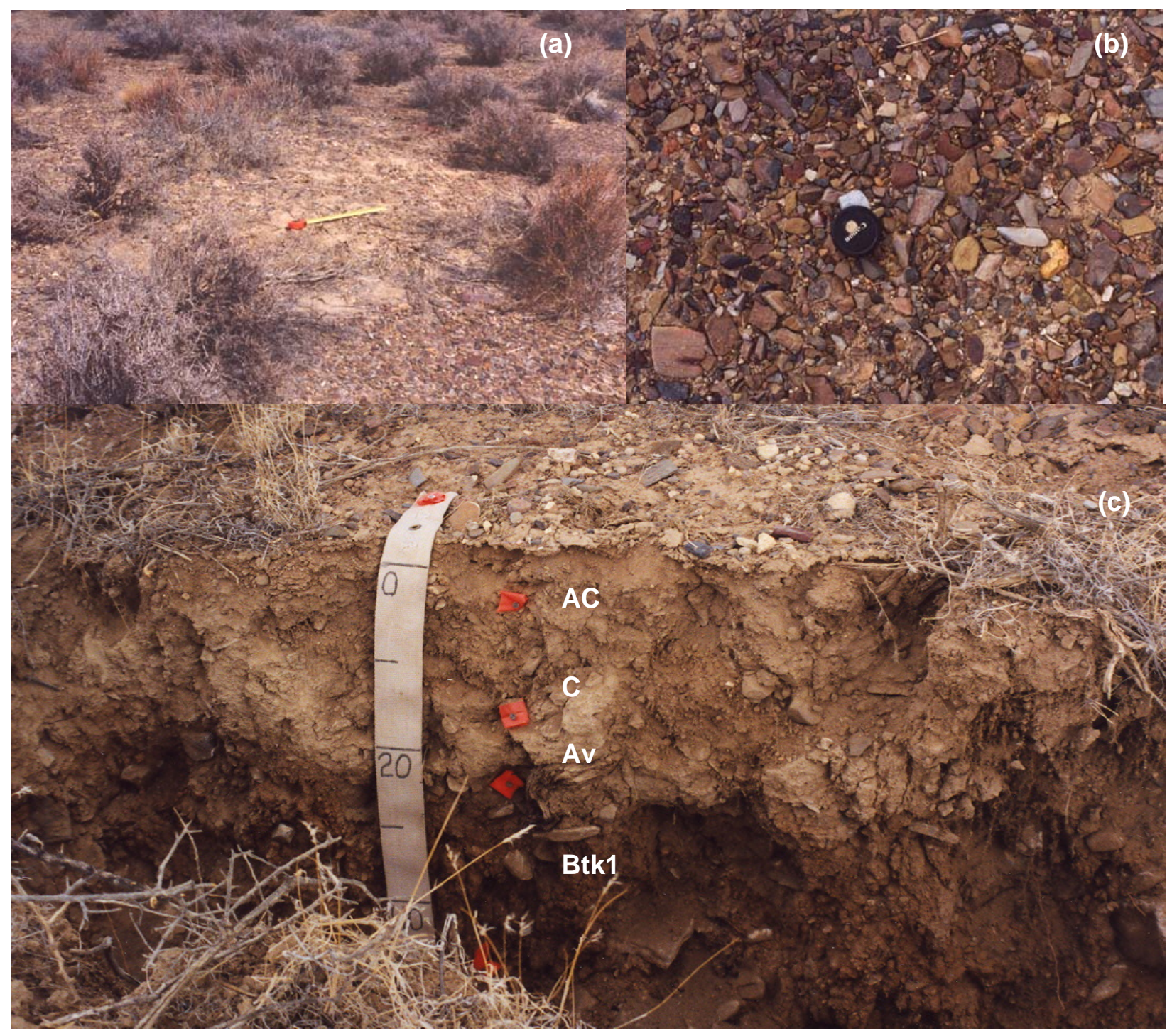

Figure 6. View of primary Analog Site 3 in Area 8 of the NTS (a). The intercanopy areas at the site have a well-developed desert pavement (b). Soil profile NA8-2 is below a Coleogyne ramosissima canopy (c).

Of particular significance is a white, silicified volcanic "Silver Lake" projectile point preform that measures $3.3 \times 3.3 \times 0.4 \mathrm{~cm}(1.3 \times 1.3 \times 0.2 \mathrm{in})$. The distinctive Silver Lake projectile point, where found elsewhere in the southern Great Basin and northern Mojave Desert, has been dated between 7,000 and 12,000 (Warren and Crabtree, 1986), and 7,500 and 11,200 years BP (Grayson, 1993). The presence of such tools and related types has been used to date terraces that formed in the last high stand of pluvial lakes in the region that occurred between 8,700 and 11,400 years BP. At this site, and for the context of this study, the presence of this tool assemblage suggests that the younger soil, which overlies the truncated paleosol, likely dates from the late Pleistocene and early Holocene. Well developed desert pavement occurs in intercaopy areas. The majority of clasts incorporated into the desert pavement range from 3 to $5 \mathrm{~cm}$ (1.2 to $2.0 \mathrm{in})$ in diameter. 
Site 4 (UTM Coordinates 0589811E, 4102659N, elevation 1,302 $\mathrm{m}$ [4,269 ft]) is an early to mid-Pleistocene surface located immediately southwest of Site 1 (Figure 7). One objective in selecting the site was to test the hypothesis that plants species newly recruited to surfaces such as Analog Site 1 have a high similarity to species composition of native plants on undisturbed surfaces nearby. A well-developed desert pavement in terms of clast alignment and sorting forms a durable crust over much of the surface. Except for occasionally large clasts, the majority of the desert pavement clasts have little surface expression above an eolian mantle. The Av horizon is approximately $7 \mathrm{~cm}(2.8 \mathrm{in})$ thick. The largest pavement clasts are in the intercanopy spaces and most clasts have well-expressed desert varnish. The majority of clasts incorporated into the intercanopy desert pavement range from 4 to $7 \mathrm{~cm}$ (1.6 to $2.8 \mathrm{in}$ ) in diameter. Compared to Sites 2 and 3, burrows are uncommon and largely restricted to shrub undercanopies, although occasional mounds of fine-grained, bioturbated soils are present where mature shrubs have died. Based on Bechtel Nevada (1998), Site 4 meets most of the criteria for a mid-Pleistocene S3 surface, for a minimum age of approximately 125,000 years BP. Perennial vegetation is co-dominated by Coleogyne ramosissima and Ephedra nevadensis, similar to Site 3, but while total cover is slightly lower, total diversity is greater. Conversely, winter annual diversity and density are the lowest at Site 4 compared to the three other sites.

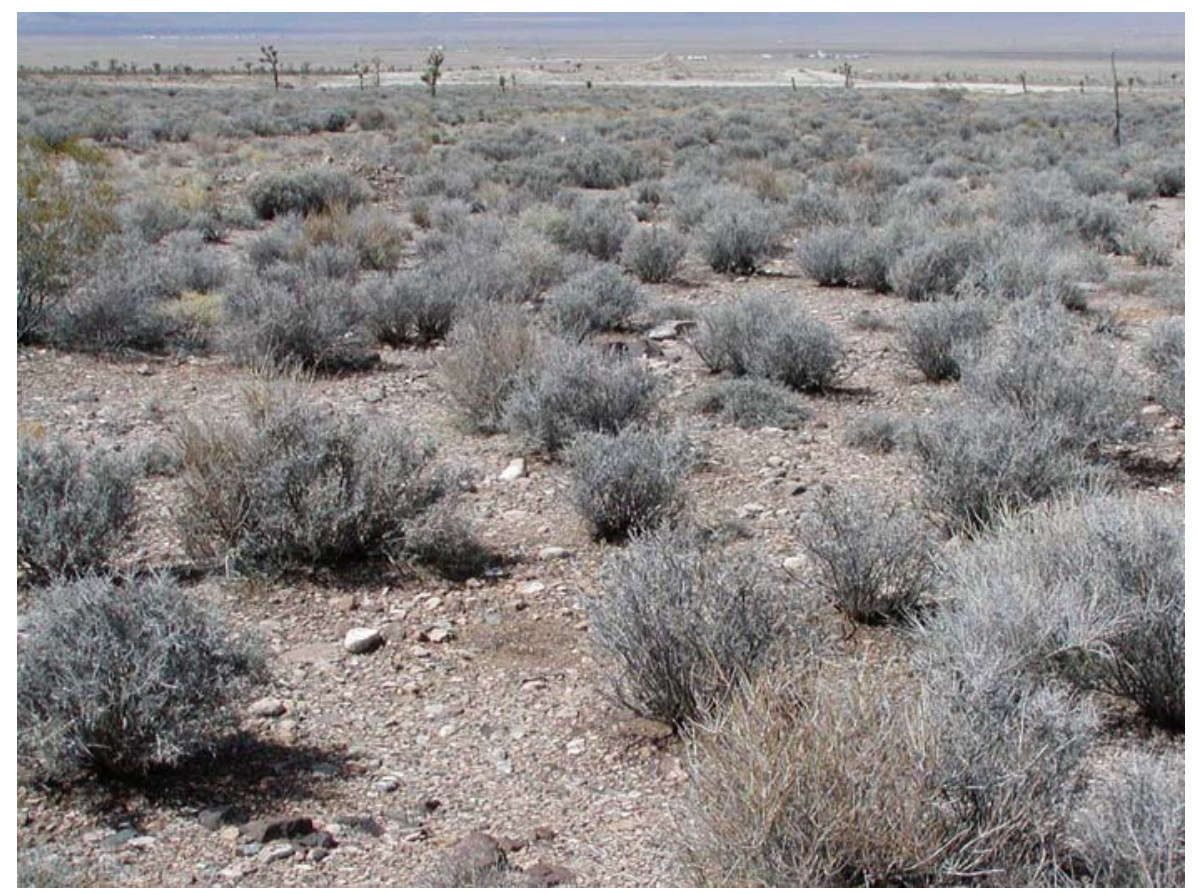

Figure 7. View of Site 4 following a rainfall event hours earlier. Well-developed pavement surface is apparent in intercanopies, as is the large number of Coleogyne ramosissima and Ephedra nevadensis. 


\section{Limitations of the Primary Analog Sites}

As with any temporal and spatial sequence of natural analog sites, there are always likely to be factors that are unique to particular sites. All four Primary Analog Sites are located in Yucca Flat. However, while there is an elevation range of only $41 \mathrm{~m}(132 \mathrm{ft})$ elevation between sites 1,2, and 4, Analog Site 3 is $202 \mathrm{~m}$ (648 ft) higher than the lowest elevation site, Analog Site $2(1,261 \mathrm{~m}[4,137 \mathrm{ft}])$. If precipitation is assumed to increase linearly between the lowest elevations on the NTS to the highest at Rainier Mesa $(2,350 \mathrm{~m}$ [7,546 ft] elevation) (Bechtel Nevada, 2001), the average annual precipitation at Analog Site 3 might be as high as $9.3 \mathrm{~cm} / \mathrm{yr}$, or $3.1 \mathrm{~cm}$ higher than at MEDA Station 3. In addition, clasts at Sites 1, 2, and 4 are dominantly carbonates, while clasts at Site 3 are primarily from volcanic tuffs. Also, because of their ages, Analog Sites 2 and 4 were subject to past climates significantly different than today. The soil of Analog Site 3 may have begun to develop in the late Pleistocene when it is estimated that annual precipitation may have been 30 to 40 percent higher, and that it occurred even more dominantly in the winter in the region than today (Spaulding, 1985; van Devender et al., 1987). These differences are noted, but the dominant

environmental processes that have influenced the site soils, plants and fauna over the previous several thousand years are still quite similar.

\section{Description of Flora}

At each of the four analog sites, a belt transect $(10 \times 50 \mathrm{~m})$ was established in March 2003 (Figures 8 through 11). One half of the transect was divided into five $(5 \times 10 \mathrm{~m})$ subplots and all perennial plants had their rectangular coordinates measured and then their canopy heights and widths measured to the nearest $\mathrm{cm}$. There had been average rainfall during the previous winter and all perennial species, if alive, would have broken bud and produced some vegetative growth prior to the start of the first site survey. Consequently, live or dead status of each plant could be accurately determined. The presence/absence of flowering was also noted. The time of death for an individual plant could not be determined, but significant mortality across all sites, especially for Indian ricegrass (Achnatherum hymneoides), probably occurred during the four years of below-normal rainfall preceding spring 2003. For about five percent of the dead plants, species identities could not be determined. Plant nomenclature is based on the Jepson Manual (Hickman, 1993). At Site 1, there were two additional $(5 \times 10 \mathrm{~m})$ subplots surveyed (Figure 8$)$ because plant densities were significantly lower than for the three other sites.

Winter annual plant diversities and densities were measured in five paired subplots $(0.5$ x $0.5 \mathrm{~m}$ ). The subplots were usually located in the adjacent half of the $10 \times 50 \mathrm{~m}$ belt transect used to measure perennial plant diversity and density to avoid surface disturbance caused during the perennial plant surveys. Paired sites were selected as 1) under the live canopy of the dominant shrub species and 2) at least $0.5 \mathrm{~m}$ from the shrub canopy edge. To ensure identification at the species level, all winter annual surveys were conducted in mid-May, when all individuals were flowering.

A general linear model was used to make statistical comparisons of site (surface-age) effects on plant diversities and densities and burrow densities with 2003 Statistical Analysis System (SAS) software. Surface-age relationships with plant parameters and animal burrows were analyzed with SigmaPlot Version 8.0. 


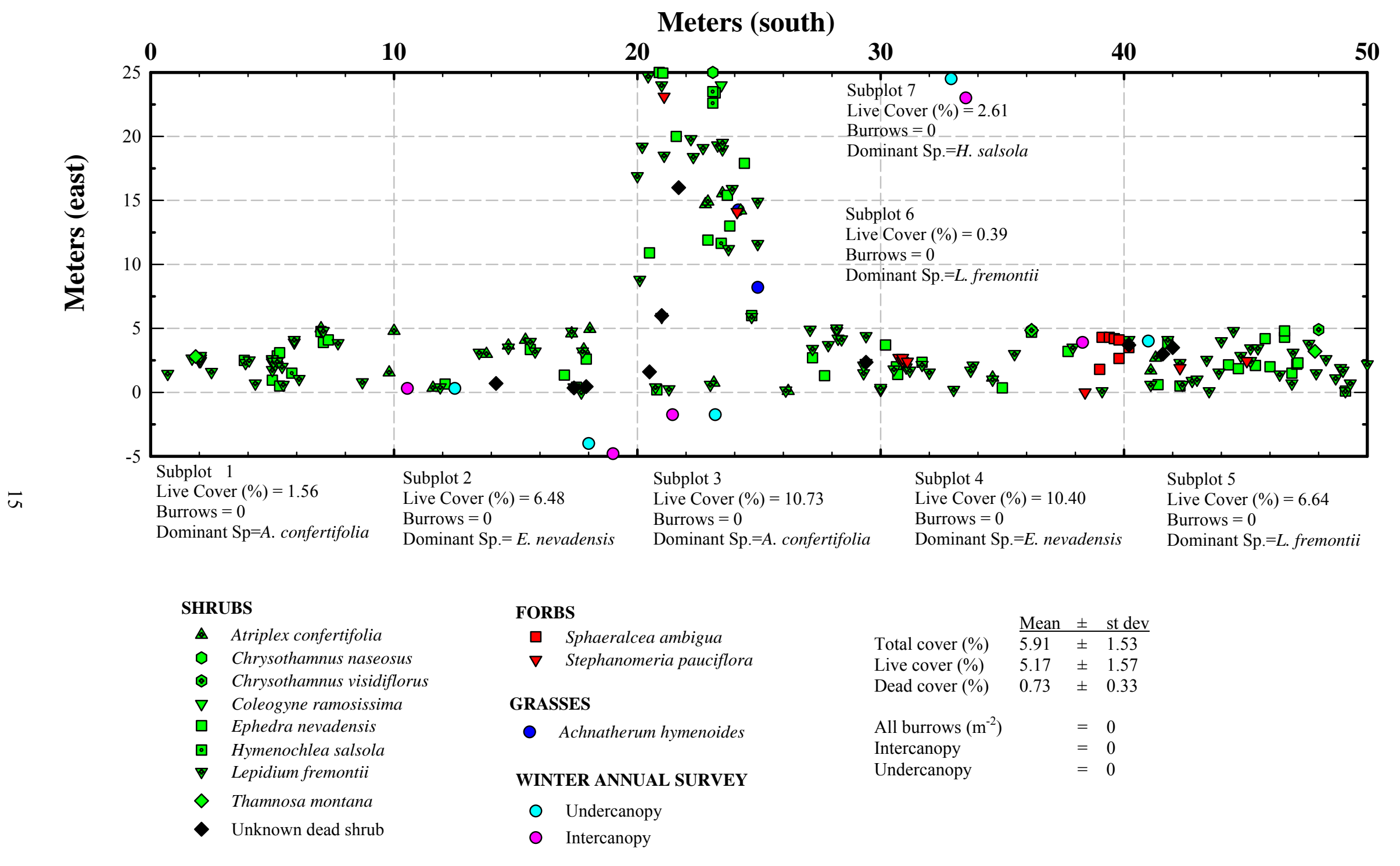

Figure 8. Perennial plant distribution within two perpendicular belt transects (5 x $50 \mathrm{~m}$ and 5 x 20 m) on Analog Site 1 ( 30 years old). Data were collected 11 March 2003. 


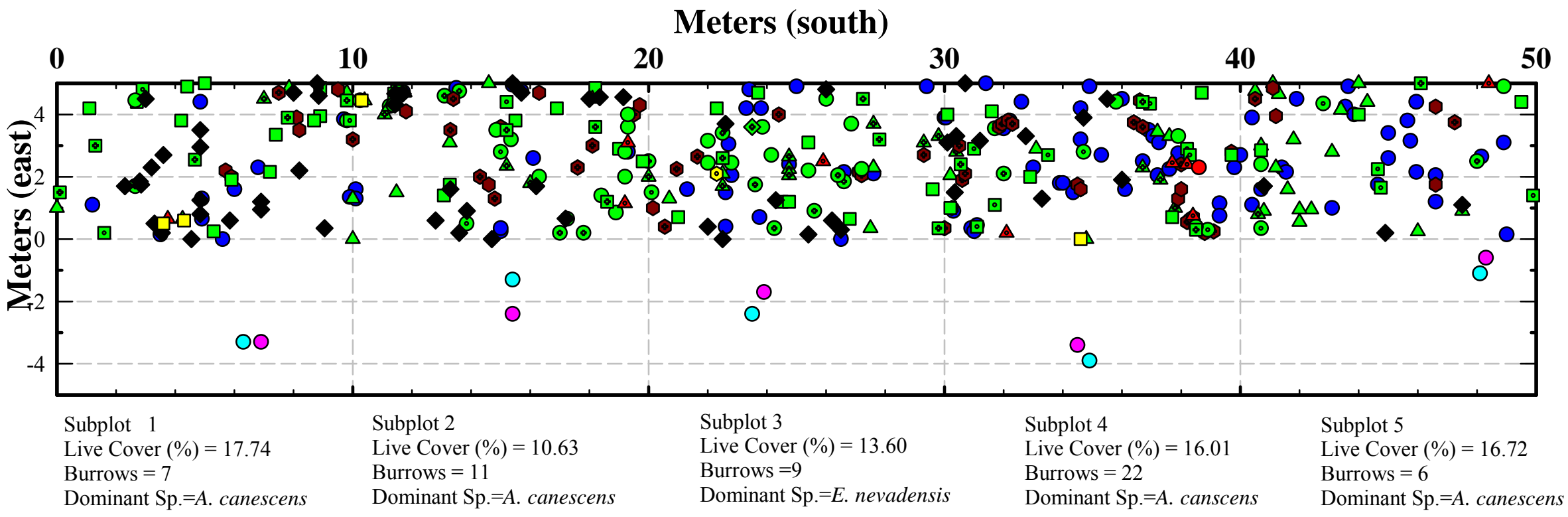

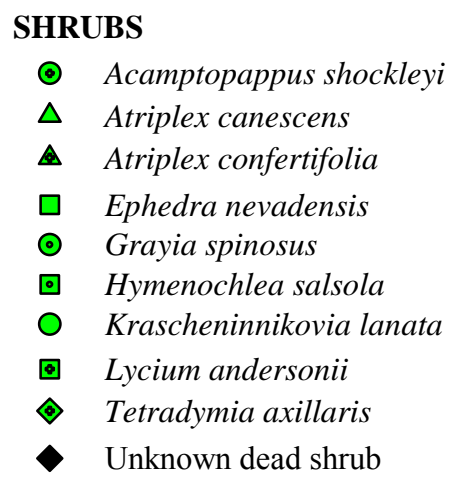

\section{CACTI / SUCCULENTS}

$\bullet \quad$ Opuntia ramosissima
$\square \quad$ Yucca brevifolia
GRASSES

- Achnatherum hymenoides

$$
\begin{array}{ll}
\text { FORBS } \\
\text { ○ } \\
\text { ○ Stephabilis pudica } \\
\text { Steria pauciflora }
\end{array}
$$

\section{BURROWS}

- Interspace

- Understory

\begin{tabular}{lrcc} 
& Mean & \pm & st dev \\
\cline { 2 - 4 } Total cover (\%) & 22.71 & \pm & 2.95 \\
Live cover (\%) & 14.94 & \pm & 2.85 \\
Dead cover (\%) & 7.77 & \pm & 1.91 \\
& & & \\
Burrows $\left(\mathrm{m}^{-2}\right)$ & 0.220 & \pm & 0.128 \\
Interspaces & 0.076 & \pm & 0.023 \\
Understory & 0.144 & \pm & 0.033
\end{tabular}

WINTER ANNUAL SURVEY

O Understory

O Interspace

Figure 9. Perennial plant distribution with a 10 x $50 \mathrm{~m}$ belt transect on Analog Site 2 (1,000 to 2,000 years old). Data were collected 14 February and 11 March 2003. 


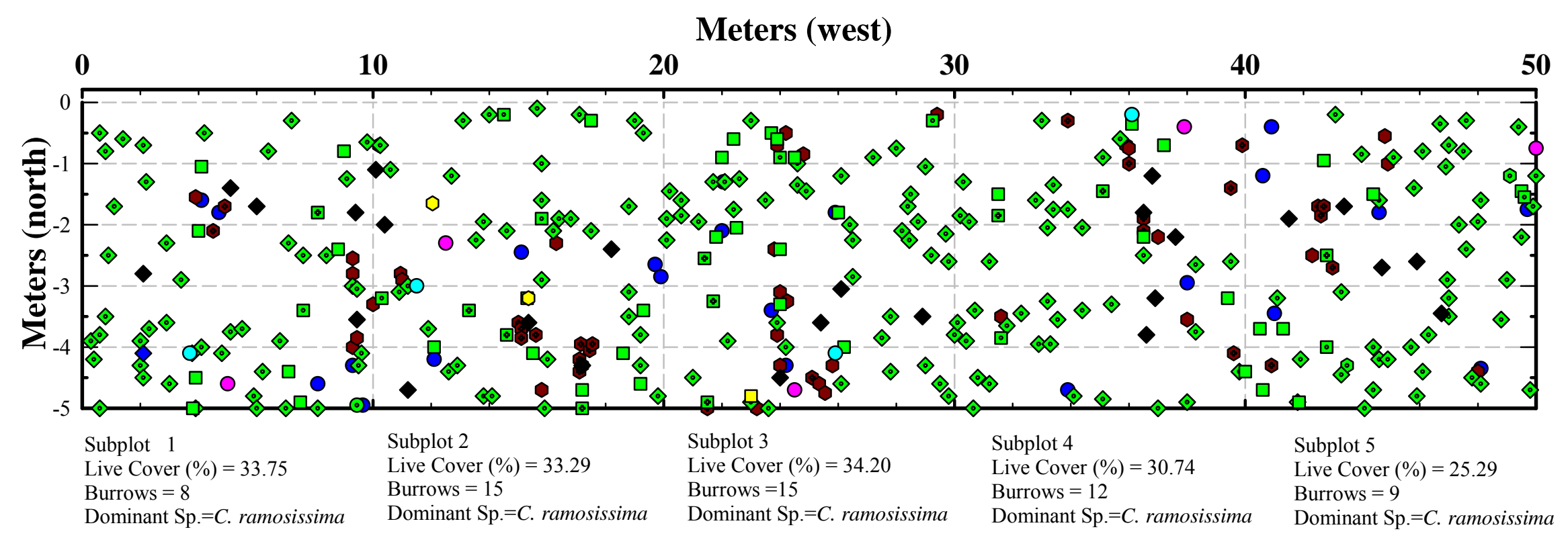

\section{SHRUBS}

- Chrysothamnus visidiflorus

- Coleogyne ramosissima

$\square \quad$ Ephedra nevadensis

๑ Grayia spinosa

๑ Hymenochlea salsola

남 Lycium andersonii

- Unknown dead shrub

\section{CACTI / SUCCULENTS}

- Opuntia basilaris
$\square \quad$ Yucca brevifolia

\section{GRASSES}

- Achnatherum hymenoides

- Poa secunda

\section{BURROWS}

- Interspace

- Understory

\section{WINTER ANNUAL SURVEY}

O Understory

○ Interspace

Figure 10. Perennial plant distribution with a 10 x $50 \mathrm{~m}$ belt transect on Analog Site 3 (7,500 to 12,000 years old). Data were collected 25

\begin{tabular}{lrcc} 
& Mean & \pm & st dev \\
\cline { 2 - 4 } Total cover (\%) & 37.92 & \pm & 1.22 \\
Live cover (\%) & 31.45 & \pm & 1.65 \\
Dead cover (\%) & 6.49 & \pm & 0.84 \\
& & & \\
Burrows $\left(\mathrm{m}^{-2}\right)$ & 0.236 & \pm & 0.029 \\
Interspaces & 0.104 & \pm & 0.030 \\
Understory & 0.132 & \pm & 0.033
\end{tabular}

$\begin{array}{llll}\text { Interspaces } & 0.104 & \pm & 0.030 \\ \text { Understory } & 0.132 & \pm & 0.033\end{array}$

\footnotetext{
March 2003.
} 



SHRUBS
○ Acamptopappus shockleyi
- Ambrosia dumosa
$\triangle$ Atriplex canescens
- Ariplex confertifolia
- Chrysothamnus visidiflorus
- Coleogyne ramosissima
(- Encelia virginensis
- Ephedra nevadensis
○ Grayia spinosa
- Lepidium fremontii
- Lycium andersonii
- Tetradymia axillaris
$\diamond$ Thamnosa montana
- Unknown dead shrub

GRASSES

\begin{tabular}{|c|c|c|c|c|c|}
\hline \\
\hline - & Achnatherum hymenoides & & Mean & \pm & st dev \\
\hline$\Delta$ & Achnatherum speciosum & Total cover $(\%)$ & 25.94 & \pm & 1.15 \\
\hline & & Live cover (\%) & 22.93 & \pm & 1.29 \\
\hline FOR & & Dead cover $(\%)$ & 3.14 & \pm & 0.21 \\
\hline & Stanleya pinnata & Burrows $\left(\mathrm{m}^{-2}\right)$ & 0.024 & \pm & 0.007 \\
\hline & & Interspaces & 0.008 & \pm & 0.008 \\
\hline BUR & Rows & Understory & 0.016 & \pm & 0.07 \\
\hline 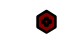 & Interspaces & & & & \\
\hline - & Understory & & & & \\
\hline WIN & TER ANNUAL SURVEY & & & & \\
\hline 0 & Understory & & & & \\
\hline 0 & Interspaces & & & & \\
\hline
\end{tabular}

Figure 11. Perennial plant distribution with a 10 x $50 \mathrm{~m}$ belt transect on Analog Site $4(125,000$ years old). Data were collected 18 March 2003. 


\section{Description of Fauna}

A literature review was conducted to determine the types of small mammals found on various parts of the NTS, their burrowing habits, and phenomena that would restrict the depth and distribution of burrows. In addition, at Primary Analog Sites 1, 2, and 3, trenches were constructed to look at the depth of burrowing by small mammals beneath dominant perennial shrubs and in intercanopy locations. In addition, the frequency of burrows and their diameter were measured, and their proximity to shrub undercanopies or intercanopy areas was measured and recorded in conjunction with vegetation transects to evaluate linkages between small mammal activity and plant distribution. No determinations of the organisms (reptile, mammal or insect) responsible for constructing the burrows were made.

Generally, burrowing by animals into cover surfaces is viewed as having potential negative consequences for ET covers for the following reasons: 1) burrows could become preferential pathways for water to infiltrate into the cover; and 2) burrows for animals could actually expose waste, or create direct pathways of water to the surface or migration of gases to the surface from waste. For establishing vegetation on ET covers, concern has been cited about small mammals foraging on newly emergent plants on covers, delaying the establishment of effective plant covers for transpiration. In addition, of recent interest is the potential role of burrowing insects such as termites and ants in reaching the waste and accelerating the breakdown of some types of waste containers and translocating material to the surface of waste cells (Hooten et al., 2001). Insect bioturbation was beyond the scope of this study. However, see the "Additional Research" section for a discussion of ongoing work by Neptune and Company (M.M. Hooten, personal communication, 2003).

\section{Soil Morphology}

Soils were described from trenches excavated at Primary Analog Sites 1, 2, and 3. Trenches were dug to a depth at which all soil horizons were exposed, although the depth of maximum fine rooting was reached at each site. Representative bulk soil samples for laboratory analysis were collected from each horizon in each profile. Soil characteristics were described according to standard methods employed by the U.S. Department of Agriculture (USDA) Natural Resources Conservation Service (NRCS) Soil Survey (USDA, 1999) and soil geomorphic methods of Birkeland (1999). One profile at each site that underlies a shrub canopy was described to observe soil processes as related to faunal and floral bioturbation. A second soil profile underlying the intercanopy between shrubs was also described at Analog Sites 2 and 3. Features related to faunal and floral bioturbation were noted in regards to potential impacts to engineered covers.

All soils sampled in this investigation were analyzed in the Desert Research Institute (DRI) Soil Characterization and Quaternary Pedology Laboratory for the following physical and chemical parameters: particle-size distribution using laser light scattering (Gee and Or, 2002), carbonate content using Chittick apparatus (Dreimanis, 1962; Machette, 1985) and electrical conductivity (Rhoades, 1996). Particle-size distribution of the less than $2 \mathrm{~mm}$ fraction is shown as percent weight of each major fraction (sand, silt, clay) and weight percent of each subfraction. The minimum size for each partial size distribution analysis size class is presented in Table 1. Abbreviations used in soil morphology descriptions are listed in Table 2. 
Table 1. Particle size classification scheme.

\begin{tabular}{llcc}
\hline Major Class & Minor Class & Minimum Size $(\mathrm{mm})$ & Minimum Size (phi) \\
\hline Gravel & Gravel & 2.0 & -1.0 \\
Sand & Very coarse sand & 1.0 & 0.0 \\
& Coarse sand & 0.5 & 1.0 \\
& Medium sand & 0.25 & 2.0 \\
& Fine sand & 0.125 & 3.0 \\
& Very fine sand & 0.0625 & 4.0 \\
\multirow{2}{*}{ Silt } & Coarse silt & 0.0015 & 6 \\
& Fine silt & 0.0002 & 9 \\
Clay & Clay & $<0.0002$ & $<9$ \\
\hline
\end{tabular}

Note: Percent weight is reported for the fine-earth fraction $(<2 \mathrm{~mm})$.

\section{Soil Hydraulic Properties}

\section{Use of Tension Infiltrometer}

The tension infiltrometer (TI) method (Ankeny et al., 1988; Reynolds and Elrick, 1991) was used for determining the soil hydraulic properties of the surface soil at each of the four field plots. Field plots were chosen in collaboration with the geomorphic and flora studies. Paired locations of canopy and intercanopies were identified and pin-flagged appropriately during the flora surveys. Paired locations of canopy and intercanopies were identified in undisturbed areas immediately adjacent to the transects and were pin-flagged appropriately. They were chosen based on 1) whether the paired locations were representative of the surveyed area, and 2) visual observation that the undercanopy and intercanopy areas were large enough to support triplicate measurements with a 20 -cm-diameter disc. Five paired locations were identified at each surface, and two were chosen from each surface for infiltration measurements. The locations for the canopy area were chosen to maximize the spacing between measurements (i.e., $120^{\circ}$ would be optimal); however, $120^{\circ}$ was not always possible given the specific geometry of each studied canopy area, so the center of the infiltrometer base was placed as far apart as possible. The locations for the intercanopy were chosen to be within one to two meters of the shrub used for canopy measurements. Efforts were made to keep the measurement locations as close as possible without causing overlap of the wetting front, typically $50 \mathrm{~cm}$ apart. Triplicate measurements were taken whenever possible at each paired locations (ideally this led to six tests per location; 12 per surface) to account for spatial variability of hydraulic properties. In some cases, time allowed for more measurement locations to be sampled, and these are indicated when appropriate. Circled pairs are included on Figures 8 through 11 for Sites 1 through 4, respectively. 
Table 2. Soil morphology abbreviations.

\begin{tabular}{|c|c|c|c|}
\hline $\begin{array}{l}\text { Structure } \\
\text { Grade } \\
1=\text { weak } \\
2=\text { moderate } \\
3=\text { strong }\end{array}$ & $\begin{array}{l}\text { Size } \\
\mathrm{c}=\text { coarse } \\
\mathrm{m}=\text { medium } \\
\mathrm{f}=\text { fine }\end{array}$ & $\begin{array}{l}\text { Type } \\
\text { sbk = subangular blocky } \\
\text { abk = angular blocky } \\
\text { pr }=\text { prismatic } \\
\text { pl = platy } \\
\text { sg = singles grain } \\
\mathrm{m}=\text { massive }\end{array}$ & $\begin{array}{l}\text { Other } \\
:=\text { parting to (e.g., pr:pf) } \\
+=\text { consists of one or more types } \\
\text { to }=\text { grades from one type to } \\
\text { another }\end{array}$ \\
\hline $\begin{array}{l}\text { Consistency } \\
\text { Dry } \\
\text { lo = loose } \\
\text { so = soft } \\
\text { sh = slightly hard } \\
\mathrm{h}=\text { hard } \\
\text { vh = very hard }\end{array}$ & $\begin{array}{l}\text { Moist } \\
\text { lo = loose } \\
\text { vfr = very friable } \\
\text { fr = friable } \\
\text { fi = firm } \\
\text { vfi = very firm }\end{array}$ & $\begin{array}{l}\text { Wet - Stickiness } \\
\text { so = nonsticky } \\
\text { vss = very slightly sticky } \\
\text { ss = slightly sticky } \\
\text { s = sticky }\end{array}$ & $\begin{array}{l}\text { Wet } \text { - Plasticity } \\
\text { po = nonplastic } \\
\text { vps = very slightly plastic } \\
\text { ps = slightly plastic } \\
\text { p = plastic }\end{array}$ \\
\hline $\begin{array}{l}\text { Roots } \\
\text { Abundance } \\
\text { v1 = very few } \\
1=\text { few } \\
2 \text { = common } \\
3=\text { many }(50 \text { to } 75 \%)\end{array}$ & $\begin{array}{l}\text { Size } \\
\text { vf = very fine }(<0.5 \mathrm{~mm}) \\
\mathrm{f}=\text { fine }(0.5 \text { to } 2 \mathrm{~mm}) \\
\mathrm{m}=\text { medium }(2 \text { to } 5 \mathrm{~mm})\end{array}$ & $\begin{array}{l}\text { Pores } \\
\text { Abundance } \\
\text { v1 = very few } \\
1=\text { few } \\
2=\text { common } \\
3=\text { many }(50 \text { to } 75 \%)\end{array}$ & $\begin{array}{l}\text { Size } \\
\text { vf = very fine }(<0.5 \mathrm{~mm}) \\
\mathrm{f}=\text { fine }(0.5 \text { to } 2 \mathrm{~mm}) \\
\mathrm{m}=\text { medium }(2 \text { to } 5 \mathrm{~mm}) \\
\text { Type } \\
\mathrm{t}=\text { tubular } \\
\mathrm{i}=\text { interstitial } \\
\mathrm{v}=\text { vesicular }\end{array}$ \\
\hline $\begin{array}{l}\text { Cutans } \\
\text { Abundance } \\
\text { v1 = very few }(<5 \%) \\
2=\text { few }(2 \text { to } 25 \%) \\
3=\text { common }(25 \text { to } 50 \%) \\
4=\text { many }(50 \text { to } 75 \%) \\
5=\text { nearly continuous }(90 \%+)\end{array}$ & $\begin{array}{l}\text { Distinctness } \\
\mathrm{f}=\text { faint } \\
\mathrm{d}=\text { distinct } \\
\mathrm{p}=\text { prominent }\end{array}$ & $\begin{array}{l}\text { Location } / \text { Type } \\
\text { po = along pores } \\
\text { co = colloid coats on grains } \\
\text { br }=\text { bridging grains } \\
\text { pf }=\text { along ped faces }(\text { co }+ \text { br })\end{array}$ & $\begin{array}{l}\text { pr:pf along prismatic ped faces } \\
\text { bk:pf along blocky ped faces } \\
\text { Lam = lamellae } \\
\text { si = silt coatings }\end{array}$ \\
\hline $\begin{array}{l}\text { Horizon Boundary } \\
\text { Thickness } \\
\mathrm{a}=\operatorname{abrupt}(<2 \mathrm{~cm}) \\
\mathrm{c}=\text { clear }(2 \text { to } 5 \mathrm{~cm}) \\
\mathrm{d}=\operatorname{diffuse}(>5 \mathrm{~cm})\end{array}$ & $\begin{array}{l}\text { Topography } \\
\text { S = smooth } \\
\text { w = wavy } \\
i=\text { irregular }\end{array}$ & $\begin{array}{l}\text { Texture } \\
\mathrm{s}=\text { sand } \\
\text { ls = loamy sand } \\
\text { sl = sandy loam } \\
1=\text { loam }\end{array}$ & $\begin{array}{l}\text { sil = silt loam } \\
\text { scl = sandy clay loam } \\
\text { sicl = silty clay loam } \\
\text { cl = clay loam }\end{array}$ \\
\hline $\begin{array}{l}\text { Carbonates } \\
\text { Effervescence } \\
\text { none = none } \\
\text { ev = slightly } \\
\text { e = noticeably } \\
\text { es = strongly } \\
\text { ve = violently }\end{array}$ & $\begin{array}{l}\text { Abundance (coatings) } \\
\text { vpat = very patchy } \\
\text { pat = patchy } \\
\text { nc = nearly continuous }\end{array}$ & $\begin{array}{l}\text { Abundance (other) } \\
\text { v1 = very few }(<5 \%) \\
2=\text { few }(2 \text { to } 25 \%) \\
3=\text { common }(25 \text { to } 50 \%) \\
4=\text { many }(50 \text { to } 75 \%) \\
5=\text { nearly continuous }(90 \%+)\end{array}$ & $\begin{array}{l}\text { Distinctness } \\
\mathrm{f}=\text { faint } \\
\mathrm{d}=\text { distinct } \\
\mathrm{p}=\text { prominent }\end{array}$ \\
\hline $\begin{array}{l}\text { Size } \\
\mathrm{f}=\text { very fine }(<0.5 \mathrm{~mm}) \\
\mathrm{m}=\text { medium }(2 \text { to } 5 \mathrm{~mm}) \\
\mathrm{c}=\text { coarse }(<5 \mathrm{~mm})\end{array}$ & $\begin{array}{l}\text { Location / Type } \\
\text { sf = filamentous } \\
\text { sm = soft masses } \\
\text { hss = horizontal seams or bands }\end{array}$ & \multicolumn{2}{|c|}{$\begin{array}{l}\text { vss }=\text { vertical seams or tongues } \\
\text { co:bot }=\text { coatings on clasts bottoms } \\
\text { co:top = coatings on clasts tops }\end{array}$} \\
\hline
\end{tabular}

NOTE: Soil morphologic abbreviations typically combine the rows for each heading going across from left to right. For example, a weak, medium-sized platy structure parting to a weak, fine, subangular blocky structure would simply abbreviate to $1 \mathrm{mpl}: 1 \mathrm{fsbk}$

Measurements were taken by first lightly clearing away surface debris and stones in the intercanopy, and duff from the canopy area. A steel template was placed onto the soil surface and leveled appropriately. Wetted contact sand was carefully spread onto the soil surface and within the template, to maximize the hydraulic contact between the membrane material on the TI and the soil surface. The TI was then filled with water, checked for proper adjustment of tension, and then placed carefully onto the sand pad. Timing of when the TI was placed 
onto the soil surface was carefully recorded into the logbooks, as this information is important for subsequent computer analyses. Once stabilized in place, water bubbling through the reservoir and Marriote tubing at the same rates was used as an indication that the infiltrometer was operating properly. Data were collected from differential pressure transducers (Casey and Derby, 2002) at intervals of between 15 seconds and 1 minute, depending on the logger unit and soil surface. Manual readings were taken periodically to verify operation and to better identify when the intake rate was at or near steady state. At that time, the infiltrometer was reset to a lower tension level. Four to five tension steps were used for each test, typically at levels set to $-12,-9,-6,-3$, and 0 (saturation) $\mathrm{cm}$.

At the conclusion of each test, the infiltrometer and contact sand were removed and a bulk density sample was taken. Samples were taken with a soil ring $(5 \mathrm{~cm}$ diameter by 2.5 $\mathrm{cm}$ high) pressed into the soil near the center of the infiltrated area. The ring was removed using a hand trowel and leveled appropriately to better define the sample volume. Samples were stored in Ziploc ${ }^{\mathrm{TM}}$ bags to prevent water loss, returned to the laboratory in Las Vegas for final volumetric water content, and then shipped to the soils laboratory at DRI in Reno, $\mathrm{NV}$, for analysis of particle-size distribution. Data were downloaded from the datalogger to a personal computer and then post-processed at DRI.

\section{Wooding's Analysis}

Vertical infiltration is initially governed by capillarity or sorptivity of water into the soil matrix, containing both a vertical and horizontal component. Long-time infiltration becomes gravity driven and linear with time as soil capillarity forces are reduced. This long-time infiltration is then assumed to be at steady state. Based on Gardener's exponential K(h) function, three-dimensional, steady-state infiltration from a circular source was solved by Wooding (1968)

$$
q(h)=K s a t_{w} \exp \left(\alpha_{w} h\right)\left(1+\frac{4}{\pi r \alpha_{w}}\right)
$$

where $\mathrm{q}(\mathrm{h})$ is the steady-state infiltration $\left(\mathrm{cm} \mathrm{sec}^{-1}\right)$ and $\mathrm{r}$ is the infiltrometer radius $(\mathrm{cm})$. The term left of the parenthesis is representative of vertical gravity flow and the term on the right accounts for lateral movement due to capillarity. The resulting equation contains two unknowns, Ksat ${ }_{\mathrm{w}}$ and $\alpha_{\mathrm{w}}$. Using the TI through a range of tensions, paired values of flux $\mathrm{q}(\mathrm{h})$ and tensions (h) are obtained. These known values are inputted to a nonlinear least-squares regression routine to solve for the two unknowns (e.g., $\mathrm{Ksat}_{\mathrm{w}}$ and $\alpha_{\mathrm{w}}$ ) by minimizing error through iterative solutions (Logsdon and Jaynes, 1993).

\section{Parameter Estimation}

In addition to using Wooding's solution for obtaining $\mathrm{Ksat}_{\mathrm{w}}$ and $\alpha_{\mathrm{w}}$, a complete set of hydraulic properties can be obtained through numerical inversion of the cumulative infiltration data $\left.(\mathrm{mL} \mathrm{sec})^{-1}\right)$ and known changes of boundary conditions. To complete these analyses, an axisymmetric, finite-element code was applied (HYDRUS-2D, Simunek et al., 1996) to iteratively optimize parameters found in the van Genuchten (1980) form of the soil water retention curve, and in the hydraulic conductivity equation derived by Mualem (1976) and modified by van Genuchten (1980). The retention curve has the form: 


$$
\theta_{e}(h)=\frac{\theta(h)-\theta_{r}}{\theta_{s}-\theta_{r}}=\frac{1}{\left(1+\left|\alpha_{v g} h\right|^{n}\right)^{m}} \mathrm{~h}<0
$$

and the unsaturated hydraulic conductivity function is defined as a function of $\theta$ :

$$
K(\theta)=K_{s a t} \theta_{e}^{1 / 2}\left[1-\left(1-\theta_{e}^{1 / m}\right)^{m}\right]^{2} \mathrm{~h}<0
$$

where $\theta_{\mathrm{e}}$ is the effective volumetric water content, $\theta_{\mathrm{s}}$ is the saturated volumetric water content, $\theta_{\mathrm{r}}$ is the residual water content as $\mathrm{h} \rightarrow-\infty, \mathrm{n}$ and $\mathrm{m}$ are empirical parameters where $\mathrm{m}$ $=1-1 / \mathrm{n}, \mathrm{Ksat}_{\mathrm{vg}}$ is the saturated conductivity using the inversion method, and $\alpha_{\mathrm{vg}}\left(\mathrm{cm}^{-1}\right)$ is an empirical fitting parameter similar, though not equal, to the inverse air entry value. The parameters are obtained through the use of a Levenburg-Marquardt optimization procedure, which seeks to minimize the differences between measured responses in the field (e.g., cumulative flux) versus those predicted using the model. The objective function that results from the optimization routine is calculated using:

$$
\Phi(b, q, p)=\sum_{j=1}^{m_{q}} v_{j} \sum_{i=1}^{n_{q j}} w_{i, j}\left[q_{j}^{*}\left(z, t_{i}\right)-q_{j}\left(z, t_{i}, b\right)\right]^{2}
$$

where the first term on the right-hand side represents deviations between the measured and calculated space-time variables (e.g., observed pressure heads, water contents, and/or concentrations at different locations and/or time in the flow domain, or the actual or cumulative flux versus time across a boundary of specified type). In this term, $\mathrm{m}_{\mathrm{q}}$ is the number of different sets of measurements, $\mathrm{n}_{\mathrm{qj}}$ is the number of measurements in a particular measurement set, $\mathrm{q}_{\mathrm{j}}{ }^{*}\left(\mathrm{x}, \mathrm{t}_{\mathrm{i}}\right)$ represents specific measurements at time $\mathrm{t}_{\mathrm{i}}$ for the $\mathrm{jth}$ measurement set at location $\mathrm{x}\left(\mathrm{x}, \mathrm{t}_{\mathrm{i}}\right), \mathrm{q}_{\mathrm{j}}\left(\mathrm{x}, \mathrm{t}_{\mathrm{i}}, \mathrm{b}\right)$ are the corresponding model predictions for the vector of optimized parameters $b$ (e.g., $\theta_{r}, \theta_{s}, a, n$, and $K_{s}$ ), and $v_{j}$ and $w_{i, j}$ are weights associated with a particular measurement set or point, respectively. The second term of $M$ represents differences between independently measured and predicted soil hydraulic properties (e.g., retention, $\theta(\mathrm{h})$ and/or hydraulic conductivity, $K(\theta)$ or $K(h)$ data), while the summation indices have similar meanings as for the first term but not for the soil hydraulic properties. HYDRUS-2D completes iterating when a global minimum $M(b, q, p)$ is found.

The result of the data analysis is a series of fitting parameters and physical properties of the soil that will be cross-correlated to evaluate the strength of association between geomorphic and age setting and the hydraulic properties. Correlation tables will be constructed to better identify and explain the most sensitive parameters that are affecting the hydraulic properties at these sites.

\section{RESULTS AND DISCUSSIONS}

\section{Flora}

Mean live perennial plant cover was significantly different between all four sites (Table 3). Mean live perennial plant cover was lowest on Site 1, the 30-year-old site (4.36 percent), and peaked on Site 3, the 7,500 to 12,500-year-old site at 31.45 percent. Dead cover was lowest on the 30 -year-old site $(0.73$ percent $)$, which was not significantly different than 
the 3.01 percent dead on Site 4. Dead cover on Site 2 (7.77 percent) did not differ significantly from Site 3 (6.47 percent).

Table 3. Mean \pm standard error for live and dead perennial plant cover in native northern Mojave Desert plant communities at four sites of varying age located at the Nevada Test Site. Means followed by the same letter in the same column are not significantly different at the $\alpha=0.05$ level.

\begin{tabular}{lcccc}
\hline Site & Age (years) & Elevation $(\mathrm{m})$ & Live Cover $(\%)$ & Dead Cover $(\%)$ \\
\hline 1 & 30 & 1,274 & $4.36 \pm 3.37 \mathrm{~d}$ & $0.73 \pm 0.33 \mathrm{~b}$ \\
2 & 1,000 to 2,000 & 1,261 & $14.94 \pm 2.85 \mathrm{c}$ & $7.77 \pm 1.91 \mathrm{a}$ \\
3 & $7,000 \mathrm{t} 12,500$ & 1,463 & $31.45 \pm 3.69 \mathrm{a}$ & $6.47 \pm 0.86 \mathrm{a}$ \\
4 & 125,000 & 1,302 & $22.93 \pm 2.88 \mathrm{~b}$ & $3.01 \pm 0.25 \mathrm{~b}$ \\
$\mathrm{~F}$ & ----- & ---- & 75.01 & 11.57 \\
$\mathrm{Pr}>\mathrm{F}$ & ---- & --- & $<0.0001$ & 0.0002 \\
\hline
\end{tabular}

Only two perennial species occurred across all four sites, $A$. hymenoides, a grass, and $E$. nevadensis, an evergreen shrub (Table 4). However, A. hymnenoides contributed very little to total live cover, while E. nevadensis was the dominant species on Site 1 and was co-dominant on the other three sites. In contrast to total live perennial cover peaking on the 7,500- to 12,500-year-old site, perennial diversity peaked on Site 2 at 9.8 species and was co-dominated by E. nevadensis and A. canescens. Atriplex canescens was relatively restricted to Site 3, being absent from Sites 1 and 2 and occurring as only a minor component of Site 4. There was no simple relationship between species diversity and total live perennial cover as suggested by the fact that Sites 1 and 2 had the least diversity $\left(5.1\right.$ and 4.6 species per $50 \mathrm{~m}^{2}$ subplot, respectively), but the greatest difference in total live cover, 4.36 percent versus 31.45 percent, respectively. However, increasing perennial diversity was usually associated with small increases in cover by various grasses, forbs, and shrubs, with some species occurring on more than one site (A. speciosum, A. confertifolia, C. viscidiflorus, C. ramosissima, $G$. spinosa, L. andersonii and $Y$. brevifolia), while nine species were unique to a site ( $C$. nauseosus, S. ambigua, and S. pauciflora on Site 1). Cactus species were absent on the youngest and oldest sites and uncommon on Analog Sites 2 and 3.

For sites and microsites combined, a total of 31 winter annual species were found (Figure 12), including five introduced species (Table 5). Winter annual plant species diversities and densities peaked on Site 2 and were similar for under shrub canopies and intercanopies between shrubs (seven and five species per $\mathrm{m}^{2}$ and 249.6 and 205.6 plants per $\mathrm{m}^{2}$, respectively). In contrast to the patterns for perennial cover and diversity, a significant and dramatic decline for winter annuals occurred on Analog Site 4, especially in the intercanopies between shrub canopies where diversity dropped to less than one species per $\mathrm{m}^{2}$ and density was only four plants per $\mathrm{m}^{2}$. Furthermore, greater than 30 percent of the population of annuals on Site 4 was composed of an introduced grass, B. madritensis, which regardless of site was overwhelmingly restricted to under canopy microsites. Among native annuals, C. fremontii had the greatest densities and occurred across all sites, though in contrast to $B$. madritensis it preferred intercanopy microsites. Other common native annuals were $M$. albicaulis, E. pringlei, and $P$. fremontii, which showed much less microsite preference than B. madritensis or $C$. fremontii. These five annual species contributed 50 to 97 percent to total annual densities for all sites and microsites. Among the other 26 species of annuals, E. deflexum had high densities in intercanopy microsites on the two youngest sites, 
and 10 species were restricted to a single site. For the introduced annual species, B. tectorum, E. cicutarium, H. glomerata, and S. iberica, all occurred on the youngest site, but across the other sites H. glomerata was not found, E. cicutarium was absent from the oldest site, and $S$. iberica was absent from Site 2.

Table 4. Diversity and percent cover by native perennial plant species in four northern Mojave Desert plant communities on variable-age surfaces located at the Nevada Test Site.

\begin{tabular}{|c|c|c|c|c|c|}
\hline \multirow[b]{2}{*}{ SPECIES } & \multirow[b]{2}{*}{ Growth Form } & \multicolumn{4}{|c|}{ Site Age in Years } \\
\hline & & 30 & 1,000 to 2,000 & 7,000 to 12,500 & 125,000 \\
\hline Achnatherum hymenoides & Grass & 0.04 & 0.30 & 0.02 & 0.05 \\
\hline Achnatherum speciosum & Grass & & 0.03 & & 0.10 \\
\hline Acamptopappus shockleyi & Shrub & & & & 0.05 \\
\hline Ambrosia dumosa & Shrub & & & & 0.94 \\
\hline Atriplex canescens & Shrub & & 5.52 & & 0.09 \\
\hline Atriplex confertifolia & Shrub & 1.28 & 1.24 & & 0.30 \\
\hline Chrysothamnus nauseosus & Shrub & 0.22 & & & \\
\hline Chrysothamnus viscidiflorus & Shrub & 0.03 & & 0.47 & 0.53 \\
\hline Coleogyne ramosissima & Shrub & 0.02 & & 21.7 & 11.93 \\
\hline Ephedra nevadensis & Shrub & $2.98 *$ & 2.39 & 8.58 & 4.85 \\
\hline Grayia spinosa & Shrub & & 0.66 & 0.25 & 0.93 \\
\hline Hymenochlea salsola & Shrub & 0.64 & 1.59 & 0.92 & \\
\hline Krascheninnikovia lanata & Shrub & & 0.57 & & \\
\hline Lepidium fremontii & Shrub & 0.76 & & & 0.06 \\
\hline Lycium andersonii & Shrub & & 2.74 & 0.56 & 2.05 \\
\hline Mirabilis pudica & Forb & & 0.25 & & \\
\hline Opunti basilaris & Cactus & & & 0.08 & \\
\hline Opuntia ramosissima & Cactus & & $<0.01$ & & \\
\hline Sphaeralcea ambigua & Forb & 0.02 & & & \\
\hline Stephanomeria pauciflora & Forb & 0.08 & & & \\
\hline Yucca brevifolia & Tree & & 0.32 & 0.01 & 3.4 \\
\hline Total diversity (all subplots) & & 10 & 12 & 9 & 13 \\
\hline Mean diversity per subplot & & $5.1 \pm 0.6$ & $9.8 \pm 0.4$ & $4.6 \pm 0.4$ & $7.2 \pm 0.6$ \\
\hline
\end{tabular}




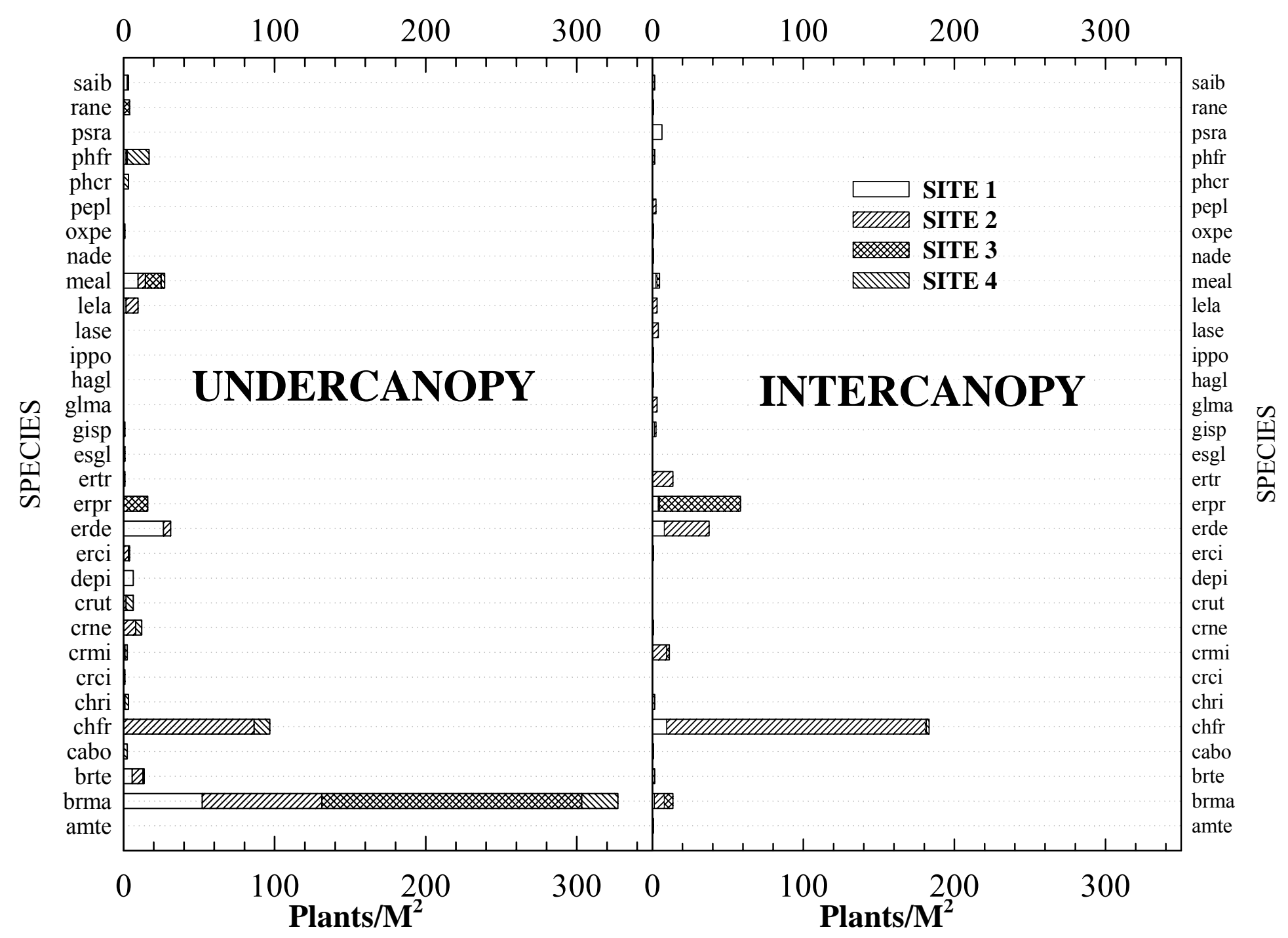

Figure 12. Winter annual individual species densities for undercanopy and intercanopy microsites within four analog sites with surfaces ranging from 30 to 125,000 years old. Data were collected on 8 and 19 May 2003 (see Table 5 for species definitions). 
Table 5. Winter annual diversity and density $\left(\mathrm{plants} / \mathrm{m}^{2}\right)$ in four northern Mojave Desert plant communities on variable-age surfaces located at the Nevada Test Site.

\begin{tabular}{|c|c|c|c|c|c|c|c|c|}
\hline \multirow[b]{3}{*}{ SPECIES } & \multicolumn{8}{|c|}{ SITE AGE (YEARS B.P.) } \\
\hline & \multicolumn{2}{|c|}{30} & \multicolumn{2}{|c|}{1,000 to 2,000} & \multicolumn{2}{|c|}{7,500 to 12,500} & \multicolumn{2}{|c|}{125,000} \\
\hline & inter $^{1}$ & under & inter & under & inter & under & inter & under \\
\hline Amsinkia tesselata (amte) & 0 & 0 & 0 & 0 & 0.8 & 0 & 0 & 0 \\
\hline Bromus madritensis* (brma) & 1.6 & 52 & 6.4 & 79.2 & 5.6 & 172 & 0 & 24 \\
\hline Bromus tectorum* (brte) & 0 & 5.6 & 1.6 & 7.2 & 0 & 0.8 & 0 & 02.4 \\
\hline Camissonia boothii (cabo) & 0 & 0 & 0.8 & 0 & 0 & 0 & 0 & 10.4 \\
\hline Chaenactis fremontii (chfr) & 9.6 & 0 & 171.2 & 86.4 & 0.8 & 0 & 1.6 & 2.4 \\
\hline Chorizanthe rigida (chri) & 0 & 0.8 & 0 & 0 & 0 & 0 & 1.6 & 0 \\
\hline Cryptantha circumscissa (crci) & 0 & 0 & 0 & 0.8 & 0 & 0 & 0 & 1.6 \\
\hline Cryptantha micromera (crmi) & 0 & 0 & 9.6 & 0.8 & 1.6 & 0 & 0 & 4 \\
\hline Cryptantha nevadensis (crne) & 0 & 0 & 0.8 & 8 & 0 & 0 & 0 & 4.8 \\
\hline Cryptantha utahensis (crut) & 0 & 0 & 0 & 1.6 & 0 & 0 & 0 & 0 \\
\hline Descurainia pinnata (depi) & 0 & 6.4 & 0 & 0 & 0 & 0 & 0 & 0 \\
\hline Erodium circutarium* (erci) & 0 & 0 & 0.8 & 3.2 & 0 & 0.8 & 0 & 0 \\
\hline Eriogonum deflexum (erde) & 8 & 0 & 29.6 & 4.8 & 0 & 0 & 0 & 0 \\
\hline Eriophyllum pringlei (erpr) & 4 & 26.4 & 0.8 & 0 & 53.6 & 16 & 0 & 0 \\
\hline Eriogonum trichopes (ertr) & 0 & 0 & 13.6 & 0 & 0 & 0 & 0 & 0.8 \\
\hline Eschscholzia glyptosperma (esgl) & 0 & 0 & 0 & 0 & 0 & 0.8 & 0 & 0 \\
\hline Gilia sp. (gisp) & 1.6 & 0 & 0.8 & 0 & 0 & 0 & 0 & 0.8 \\
\hline Glyptopleura marginata (glma) & 0 & 0 & 3.2 & 0 & 0 & 0 & 0 & 0 \\
\hline Halogeton glabrata* (hagl) & 0.8 & 0 & 0 & 0 & 0 & 0 & 0 & 0 \\
\hline Ipomopsis polycladon (ippo) & 0 & 0 & 0 & 0 & 0.8 & 0 & 0 & 0 \\
\hline Langlossia setosissima (lase) & 0 & 0 & 4 & 0 & 0 & 0 & 0 & 0 \\
\hline Lepidium lasiocarpum (lela) & 0 & 1.6 & 3.2 & 8 & 0 & 0 & 0 & 0 \\
\hline Mentzelia albicaulis (meal) & 2.4 & 9.6 & 0.8 & 4.8 & 1.6 & 10.4 & 0 & 2.4 \\
\hline Nama demissum (nade) & 0.8 & 0 & 0 & 0 & 0 & 0 & 0 & 0 \\
\hline Oxytheca perfoliata (oxpe) & 0 & 0 & 0 & 0 & 0.8 & 0 & 0 & 0.8 \\
\hline Pectocarya platycarpa (pepl) & 0.8 & 0 & 1.6 & 0 & 0 & 0 & 0 & 0 \\
\hline Phacelia crenulata (phcr) & 0 & 0 & 0 & 0 & 0 & 0 & 0 & 3.2 \\
\hline Phacelai fremontii (phfr) & 0 & 1.6 & 0 & 0.8 & 0.8 & 0 & 0.8 & 14.4 \\
\hline Psathyrotes ramosissima (psra) & 6.4 & 0 & 0 & 0 & 0 & 0 & 0 & 0 \\
\hline Rafinesquia neomexicana (rane) & 0 & 0 & 0 & 0 & 0.8 & 4 & 0 & 0 \\
\hline Salsola iberica* (saib) & 0.8 & 2.4 & 0.8 & 0 & 0 & 0 & 0 & 0.8 \\
\hline Total density (all species) & 36.8 & 106.4 & 249.6 & 205.6 & 67.2 & 204.8 & 4 & 72.8 \\
\hline Mean diversity (per subplot) & 4.2 & 3.8 & 7.0 & 5.0 & 3.2 & 3.2 & 0.8 & 5.0 \\
\hline
\end{tabular}

*Introduced species, ${ }^{1}$ inter $=$ intercanopy area and under=undercanopy area

The trends for winter annual total densities as a function of increasing surface age and microsite are shown in Figure 13. Surface age had less influence on the winter annual densities beneath shrub canopies than for intercanopy microsites. However, intercanopy spaces dominated all four sites (Table 3). Thus, when total winter annual densities are computed by weighing the density of each microsite by relative cover, the weighted curve for overall winter annual density in Figure 13 more closely resembles the curve for intercanopy densities. Consequently, as intercanopy surface soils age, they become less likely to be colonized by both native and introduced winter annuals. 


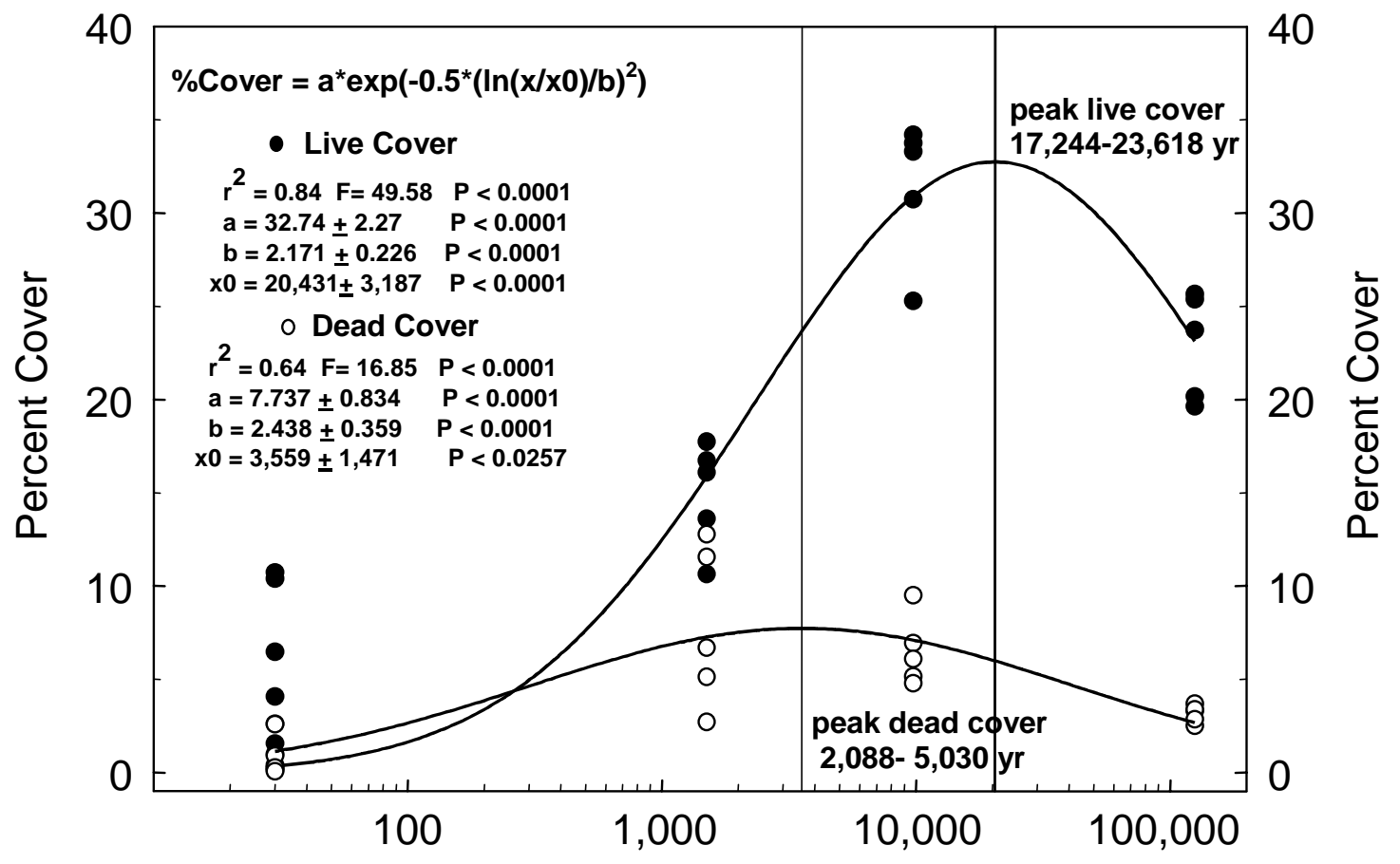

Time - Years

Figure 13. The trend in winter annual plant densities and live and dead perennial plant cover among four analog sites with surfaces ranging from 30 to 125,000 years old. The midpoint of the age range for Analog Sites 2 and 3 was used for plotting. Data were collected between 14 February and 19 May 2003.

\section{Fauna}

\section{Occurrence of Burrowing Animals}

Burrow densities, as functions of microsites, have peaks between surface ages of 1,000 and 10,000 years (Figure 14). Peak burrow density is reached slightly sooner for undercanopy than for intercanopy microsites. Comparable to trends for winter annual plant densities (Figure 13), overall weighted burrow densities are dominated by the intercanopy burrowing activity. Similarly, as intercanopy surfaces age beyond 10,000 years, they are significantly less likely to be inhabited by burrowing organisms.

Peak burrowing activity appears to coincide with peak cover of dead perennial plants (Figure 15), though cover by dead perennial plants is the least dynamic site variable depicted in Figure 8 and contributes little to an effective ET cover. These data also suggest that peak winter annual densities occur before soil surfaces at the NTS reach 1,000 years or several thousand years before peak burrowing activity. However, in terms of ET covers, winter annual populations are likely to influence potential ET from only the top 20 to $30 \mathrm{~cm}$ of soil and only for three to five months of the year. More importantly, the data suggest cover by perennial plant species is likely to continue to increase throughout a 10,000 -year period. 


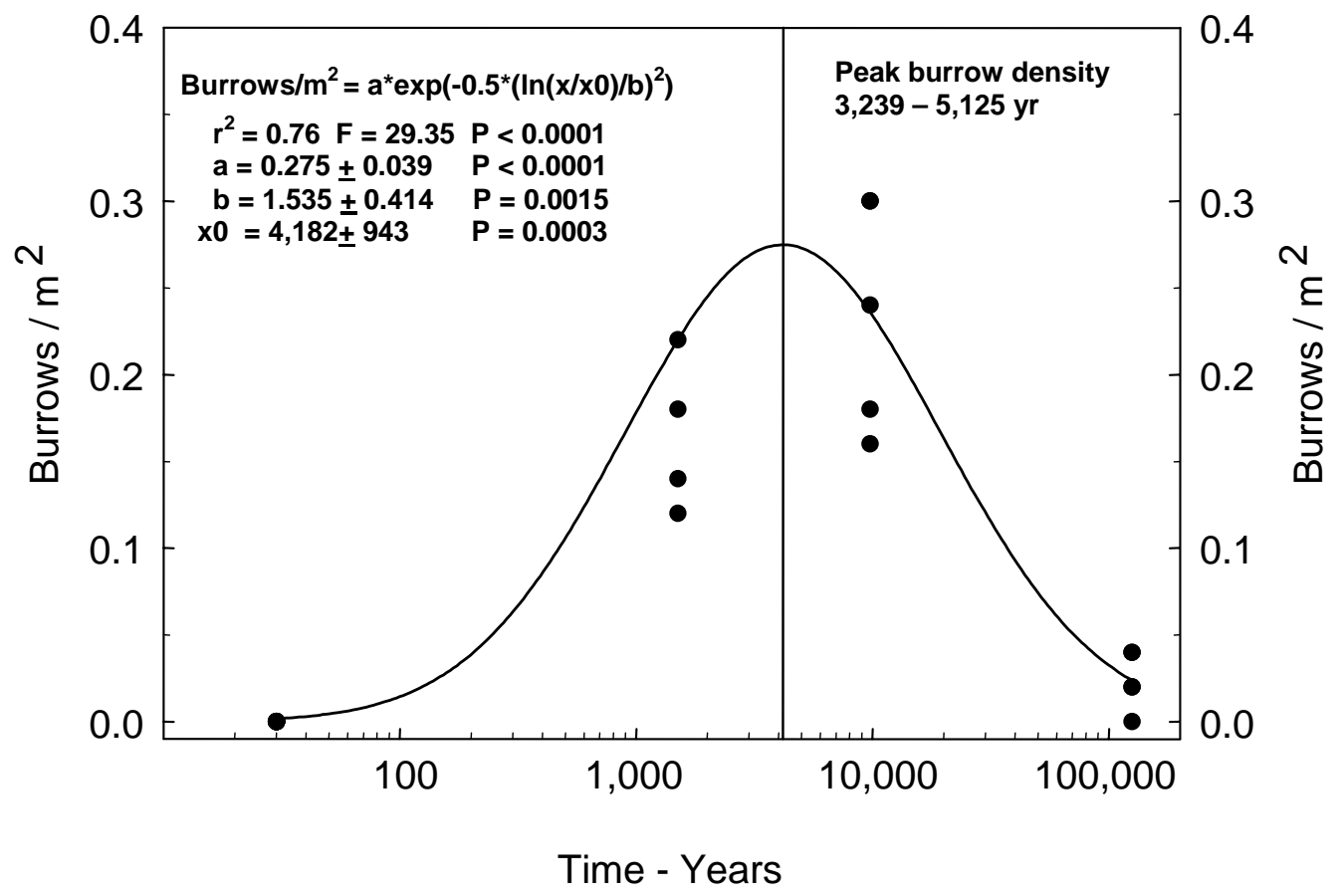

Figure 14. The influence of undercanopy and intercanopy microsites on animal burrow densities within four sites with surfaces ranging from 30 to 125,000 years old. The midpoint of the age range for Sites 2 and 3 was used for plotting. Data were collect between 14 February and 25 March 2003.

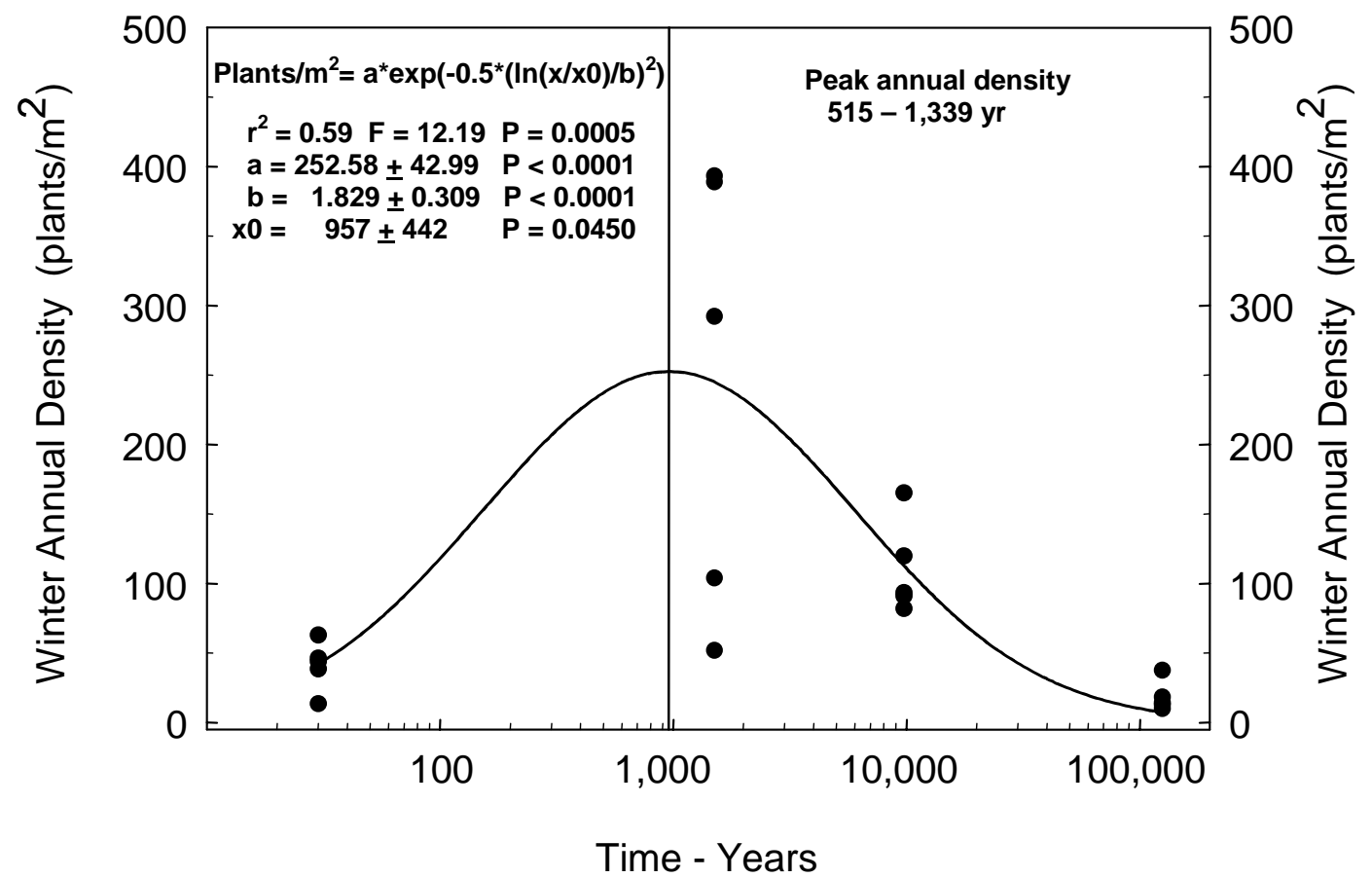

Figure 15. The influence of undercanopy and intercanopy microsites on total winter annual plant densities within four analog sites with surfaces ranging from 30 to 125,000 years old. Data were collected on 8 and 19 May 2003. The midpoint of the age range for Sites 2 and 3 was used for plotting and regression analysis included data from each subplot or $\mathrm{n}=20$. 
In terms of distribution and relative abundance, rodents are the most important group of mammals on the NTS. Most of the rodents belong to two families of burrowing rodents: Heteromyidae, including the kangaroo rats and pocket mice, and Cricetidae, the New World mice. Rodents that have been commonly sampled in the transition zone of the NTS where the analog sites are located include the Great Basin pocket mouse (Perognathus parvus), Ord's kangaroo rat (Dipodomys ordii), Great Basin kangaroo rat (Dipodomys microps), sagebrush vole (Lagurus curtatus) (Wills and Ostler, 2001) and Botta's southern pocket gopher (Thomomys bottae) (M.M. Hooten, personal communication, 2003). Burrowing mammals have been observed to increase rapidly in terms of numbers and diversity as vegetation is established on previously disturbed sites. From year to year, there is a strong correlation between the abundance of winter precipitation and small mammal numbers (Beatle, 1969). Although lizards and other rodents were observed in the vicinity of burrows at the analog sites, it is believed that they are almost exclusively using pre-existing burrows. Finally, although their burrowing at the analog sites is largely confined to the plant mounds around large perennial shrubs rather than into the soil profile, packrats (Neotoma lipida or $N$. mexicana) (Burt and Grossenheider, 1980) would also contribute to the surface disturbance on a cover with time. For example, at Analog Site 1, a Neotoma nest beneath an Ephedra nevadensis shrub contained cholla buds that the animal collected off the analog site. In addition, the entire surface of the nest was covered in clasts between 3 and $7 \mathrm{~cm}$ in their longest dimension. Packrats range outside of vegetation islands and could, among other things, be agents for distributing seeds to intercanopy areas. In general, an increasing frequency of larger clasts with depth in alluvial fan deposits may act as a natural barrier to deeper burrowing by small mammals. The only species of rodent at the NTS capable of excavating soil particles of $5 \mathrm{~cm}$ ( 2 in) or larger is the southern pocket gopher (Winkel et al., 1995).

Burrowing by small mammals in undercanopy microsites was greatest at Site 2, often resulting in small mounds with larger clasts atop finer-grained material. An indication of the extent of turnover of soil from bioturbation is the presence on the surface of clasts with carbonate rinds. These rinds form in the subsurface, and are usually eroded or dissolved away if exposed on the surface for any significant length of time.

While occurring at far lower densities than small mammals, three other burrowing animals deserve mentioning because of the potential depths and size of their borrows: the kit fox (Vulpes Velax macrotis), the North American badger (Taxidea taxus), and the desert tortoise (Gopherus agassizii). In a review of the burrowing characteristics of animals with respect to waste disposal at the RWMS, Winkel et al. (1995) identified the maximum depth of burrowing for the kit fox as $3 \mathrm{~m}$. No NTS-specific data are available for the badger, although active burrows were observed in the vicinity of Analog Sites 2 and 4.

The desert tortoise is near the limit of its range in the Mojave/Great Basin transition zone across the NTS. Tortoises are limited to approximately the southern one-third of the NTS. In addition, their abundance is about one-third or less of that in areas of the Mojave Desert in California where it is most abundant. Nevertheless, although they are not found within Yucca Flat, burrowing by tortoises is potentially a consideration for covers at the Area 5 RWMS. The depth of desert tortoise burrows varies considerably across its range. In the vicinity of Yucca Mountain and the NTS, however, tortoise burrows are comparatively 
shallow. Surveys by Brown and Rautenstrauch (1995) found that more than 70 percent of the burrows were less than $1 \mathrm{~m}$ deep.

\section{Depth of Small Mammal Burrowing}

As discussed in the soil morphology section, burrowing by small mammals is a significant process at all the analog sites, especially in the undercanopy of mature shrubs. At each site, the $\mathrm{AC}$ and $\mathrm{C}$ horizons in the vicinity of shrubs were largely composed of material brought to the surface by burrowing animals. In general, however, the maximum depth of active burrows and krotovina (abandoned and refilled tunnels made by burrowing animals) coincided with the depth of larger roots, but did not extend as deep as the finer roots. At Analog Site 1, krotovina were observed to a depth of $65 \mathrm{~cm}$. The maximum depth decreases to $30 \mathrm{~cm}$ at Site 3 . In contrast, the maximum root depth was greatest at Site $1(\geq 238 \mathrm{~cm})$, and decreased with increasing age of the sites $(\geq 118 \mathrm{~cm}$ at Site 2 and $\geq 75 \mathrm{~cm}$ at Site 3$)$.

The mounds are a combination of bioturbated soil brought to the surface, leaf litter accumulation, and probably some deposition of aeolian material. Aeolian deposition had already begun on Site 1. In some cases, although an Av horizon had not yet developed, the amount of fine sand and silt just below the surface was sufficient to hold up surface clasts on a cut face of a soil pit without the clasts collapsing into the pit. The impact of these burrows on infiltration is not fully understood, although a February 12 to 14, 2003, storm front did provide visual evidence that infiltration depth increases where burrows and krotovina are present. At Analog Site 2, in an intercanopy area, the wetting front extended to a depth of $28.9 \mathrm{~cm}(0.95 \mathrm{ft})$, but to a depth of $42.7 \mathrm{~cm}(1.4 \mathrm{ft})$ in a trench beneath an Ephedra nevadensis shrub. About $0.79 \mathrm{~cm}(0.31 \mathrm{in})$ total precipitation fell during this event.

\section{Insect Burrowing}

As previous mentioned insect burrowing is largely beyond the scope of this research. Neptune and Company, Inc., has ongoing work on the occurrence of burrowing insects (ants and termites) on the NTS (Jensen and Hooten, 2000; Hooten et al., 2001). Some 57 species of ants occur on the NTS. However, the greatest diversity occurs in the pinyon-juniper plant community at elevations higher, and where precipitation is greater, than the areas of the basins of the NTS where waste disposal facilities are located (Rundel and Gibson, 1996). Species found in transition plant communities between the Mojave and Great Basin deserts on the NTS include those that build mound nests as well as those that burrow under rocks. Although Jensen and Hooten (2000) concluded that this is evidence that some species may burrow to as deep as $5 \mathrm{~m}$, the majority are found at or above $1 \mathrm{~m}$ depth. However, based on discussions with M.M. Hooten (personal communication, 2003), Hooten et al. (2001) is undergoing significant revision and will be issued as a final report in calendar year 2004.

\section{Soil Morphology}

Results from the soil morphology are presented in Table 6 and laboratory results are presented in Table 7. The horizon type and morphology of each profile are described in more detail below. 
Table 6. Summary of soil morphology. Abbreviations used are described in Table 2.

\begin{tabular}{|c|c|c|c|c|c|c|c|c|c|c|c|c|c|c|}
\hline $\mathrm{Hor} \mathrm{z}{ }^{\mathrm{a}}$ & $\begin{array}{l}\text { Depth } \\
(\mathrm{cm}) \\
\end{array}$ & $\begin{array}{l}\text { Dry } \\
\text { Color } \\
\end{array}$ & $\begin{array}{l}\text { Moist } \\
\text { Color } \\
\end{array}$ & $\mathrm{Txt}^{\mathrm{b}}$ & Structure & Dry & Moist & Wet & Roots & Pores & Cutans $^{\mathrm{c}}$ & $\begin{array}{l}\%> \\
2 \mathrm{~mm} \\
\end{array}$ & $B d y^{d}$ & $\mathrm{CaCO}_{3}{ }^{\mathrm{e}}$ \\
\hline \multicolumn{15}{|c|}{ Site 1 [Soil No. NA3P-1] - Undercanopy } \\
\hline $\mathrm{O}$ & $0-3+$ & $\begin{array}{l}10 \mathrm{YR} \\
4 / 2 \\
\end{array}$ & $\begin{array}{l}10 \mathrm{YR} \\
3 / 2\end{array}$ & NA & $\mathrm{sg}$ & lo & lo & so, vo & NA & NA & NO & 0 & as & none \\
\hline $\mathrm{AC}$ & $0-10$ & $\begin{array}{l}10 \mathrm{YR} \\
5.5 / 2.5 \\
\end{array}$ & $\begin{array}{l}10 \mathrm{YR} \\
4 / 2\end{array}$ & ls & $\begin{array}{l}\mathrm{m} \text { to } \\
1 \mathrm{f} \mathrm{sbk}\end{array}$ & sh & vfr & so, vps & $2 \mathrm{vf}, 1 \mathrm{f}$ & $\begin{array}{l}1-2 v f \\
i+t\end{array}$ & NO & $35-45$ & aw-cs & esd \\
\hline $\mathrm{C} 1$ & $10-46$ & $\begin{array}{l}10 \mathrm{YR} \\
6 / 3 \\
\end{array}$ & $\begin{array}{l}10 Y R \\
4 / 2\end{array}$ & 1s & $\mathrm{m}$ & sh-so & vfr & so, po & $\begin{array}{l}1 \mathrm{~m}, 1 \mathrm{f}, \\
2 \mathrm{vf}\end{array}$ & $2-1 \mathrm{vft}$ & $\mathrm{NO}$ & $35-55$ & cs & esd \\
\hline $\mathrm{C} 2$ & $46-118$ & $\begin{array}{l}10 \mathrm{YR} \\
5.5 / 3\end{array}$ & $\begin{array}{l}10 \mathrm{YR} \\
3 / 3\end{array}$ & sl & $\mathrm{m}$ & sh-so & vfr & so, po & $\begin{array}{l}1 \mathrm{f}, 3-2 \\
\text { vf }\end{array}$ & $2 \mathrm{vfi}$ & NO & $35-50$ & cs-aw & esd \\
\hline $\mathrm{C} 3$ & $118-238$ & $\begin{array}{l}10 \mathrm{YR} \\
5.5 / 3 \\
\end{array}$ & $\begin{array}{l}10 Y R \\
3 / 3\end{array}$ & $\mathrm{~s}$ & $\mathrm{~m}$ & sh-so & vfr & so, po & $1-2 v f$ & $\begin{array}{l}1- \\
2 \mathrm{vfi}+\mathrm{tt}\end{array}$ & $\mathrm{NO}$ & $40-60$ & cs & esd \\
\hline \multicolumn{15}{|c|}{ Site 2 [Soil No. NA3PC-1] - Intercanopy } \\
\hline Avj1 & $0-3$ & $\begin{array}{l}10 \mathrm{YR} \\
7 / 3\end{array}$ & $\begin{array}{l}10 \mathrm{YR} \\
4 / 3\end{array}$ & sl & $\begin{array}{l}1 \mathrm{mpl}: \\
1 \mathrm{fsbk}\end{array}$ & so & vfr & & Vf-1vf & $\begin{array}{l}1- \\
2 v f i+v\end{array}$ & 2fbr silans & $20-30$ & as-aw & evd \\
\hline Avj2 & $3-8$ & $\begin{array}{l}10 \mathrm{YR} \\
7 / 3\end{array}$ & $\begin{array}{l}10 \mathrm{YR} \\
4 / 3\end{array}$ & sl & $\begin{array}{l}\text { 1-2mpl: } \\
\text { 1 fsbk }\end{array}$ & so & vfr & & $\begin{array}{l}\text { 1vf, vff, } \\
\text { vfm }\end{array}$ & $\begin{array}{l}1-2 \mathrm{vfv}, \\
1 \mathrm{vft}\end{array}$ & 2fbr silans & $25-30$ & as-aw & ed \\
\hline BCk1 & $8-18$ & $\begin{array}{l}10 \mathrm{YR} \\
6 / 4 \\
\end{array}$ & $\begin{array}{l}10 Y R \\
4 / 3\end{array}$ & $\mathrm{sl}$ & $\mathrm{m}+1 \mathrm{msbk}$ & sh-so & vfr & & $\begin{array}{l}1-2 v f, \\
\text { vff }\end{array}$ & $1-2 \mathrm{vfi}$ & $\begin{array}{l}\text { fco } \\
\text { silans }\end{array}$ & $25-30$ & cs & ed, e-es 2f-d,f,co-bots \\
\hline BCk2 & $18-34$ & $\begin{array}{l}10 \mathrm{YR} \\
7 / 3\end{array}$ & $\begin{array}{l}10 \mathrm{YR} \\
4 / 2 \\
\end{array}$ & ls & sg-m & lo-so & lo-vfr & & $\begin{array}{l}2-1 \mathrm{vf}, \\
\mathrm{vff}\end{array}$ & $1-2 \mathrm{vfi}$ & $\mathrm{NO}$ & $30-45$ & cs & ed, e 4f-d,f,co-bots \\
\hline Ck1 & $34-79$ & $\begin{array}{l}10 \mathrm{YR} \\
6 / 3 \\
\end{array}$ & $\begin{array}{l}10 \mathrm{YR} \\
4 / 2\end{array}$ & $\mathrm{~s}$ & $\mathrm{sg}$ & lo & lo & & $\begin{array}{l}2-1 v f, \\
\text { vff }\end{array}$ & $1-2 \mathrm{vfi}$ & $\mathrm{NO}$ & $50-65$ & cs & ed, e 3f-d,f,co-bots \\
\hline Ck2 & $79-109$ & $\begin{array}{l}10 \mathrm{YR} \\
6 / 3 \\
\end{array}$ & $\begin{array}{l}10 \mathrm{YR} \\
4 / 2\end{array}$ & sl & $\mathrm{sg}$ & lo & lo & & $\begin{array}{l}2-1 v f, \\
\text { vff }\end{array}$ & $1-2 \mathrm{vfi}$ & NO & $50-65$ & cs & ed, 1f,f,co-bots \\
\hline \multicolumn{15}{|c|}{ Site 2 [Soil No. NA3PC-2] - Undercanopy } \\
\hline $\mathrm{O}$ & $0-4+$ & $\begin{array}{l}10 \mathrm{YR} \\
4 / 2\end{array}$ & $\begin{array}{l}10 \mathrm{YR} \\
3 / 2\end{array}$ & NA & $\mathrm{sg}$ & lo & lo & & NA & NA & NA & 0 & as & none \\
\hline $\mathrm{AC}$ & $0-11$ & $\begin{array}{l}10 \mathrm{YR} \\
5.5 / 2.5 \\
\end{array}$ & $\begin{array}{l}10 Y R \\
4 / 2\end{array}$ & NA & $\begin{array}{l}1 \mathrm{c}, \mathrm{mpl}+ \\
1 \mathrm{msbk}\end{array}$ & sh & vfr & & $1 \mathrm{vf}$ & $\begin{array}{l}1 \mathrm{vft}, 1- \\
2 \mathrm{vfi}\end{array}$ & $2 \mathrm{fbr}$ silans & $15-25$ & aw-ai & ed, \\
\hline BCk/Avj & $11-23$ & $\begin{array}{l}10 \mathrm{YR} \\
6 / 4 \\
\end{array}$ & $\begin{array}{l}10 \mathrm{YR} \\
4 / 3\end{array}$ & sl & $\mathrm{m}+1 \mathrm{mpl}$ & sh & fr & & $1 \mathrm{vf}$ & $1 \mathrm{ft}$ & $\begin{array}{l}2 \mathrm{fbr} \text { silans } \\
\text { NO }\end{array}$ & $35-50$ & cs & esd, es 4f-d,f,co-bots \\
\hline BCk1 & $23-40$ & $\begin{array}{l}10 \mathrm{YR} \\
7 / 3\end{array}$ & $\begin{array}{l}10 \mathrm{YR} \\
4 / 2 \\
\end{array}$ & sl & sg-m & lo-so & lo-vfr & & $\begin{array}{l}2-3 v f, \\
\text { vf } f+m\end{array}$ & $1-2 \mathrm{vfi}$ & NO & $45-50$ & cs & esd, e 4f-d,f,co-bots \\
\hline BCk2 & $40-79$ & $\begin{array}{l}10 \mathrm{YR} \\
6 / 3 \\
\end{array}$ & $\begin{array}{l}10 Y R \\
4 / 2 \\
\end{array}$ & 1s & $\mathrm{sg}$ & lo & 1o & & $\begin{array}{l}2-1 v f, \\
\text { vf } \mathrm{f}+\mathrm{m}\end{array}$ & $1-2 \mathrm{vfi}$ & $\mathrm{NO}$ & $45-65$ & cs & ed, e 3f,f,co-bots \\
\hline Ck1 & $79-118$ & $\begin{array}{l}10 \mathrm{YR} \\
6 / 3 \\
\end{array}$ & $\begin{array}{l}10 Y R \\
4 / 2 \\
\end{array}$ & ls & sg-m & lo-so & lo-vfr & & $1-\mathrm{vfvf}$ & $1-2 \mathrm{vfi}$ & $\mathrm{NO}$ & $45-50$ & & ed, e 1f,f,co-bots \\
\hline
\end{tabular}


Table 6. Summary of soil morphology. Abbreviations used are described in Table 2 (continued).

\begin{tabular}{|c|c|c|c|c|c|c|c|c|c|c|c|c|c|c|}
\hline $\mathrm{Horz}{ }^{a}$ & $\begin{array}{l}\text { Depth } \\
(\mathrm{cm})\end{array}$ & $\begin{array}{l}\text { Dry } \\
\text { Color } \\
\end{array}$ & $\begin{array}{l}\text { Moist } \\
\text { Color } \\
\end{array}$ & $\mathrm{Txt}^{\mathrm{b}}$ & Structure & Dry & Moist & $\begin{array}{l}\text { Wet/ } \\
\text { Plast. }^{\mathrm{e}}\end{array}$ & Roots & Pores & Cutans $^{\mathrm{c}}$ & $\begin{array}{l}\%> \\
2 \mathrm{~mm} \\
\end{array}$ & $\mathrm{Bdy}^{\mathrm{d}}$ & $\mathrm{CaCO}_{3}{ }^{\mathrm{e}}$ \\
\hline \multicolumn{15}{|c|}{ Site 3 [Soil No. NA8-1] - Intercanopy } \\
\hline Av & $0-10$ & $\begin{array}{l}10 \mathrm{YR} \\
7 / 2\end{array}$ & $\begin{array}{l}10 \mathrm{YR} \\
4 / 3\end{array}$ & 1 & $\begin{array}{l}\text { 2-1c-mpl: } \\
1 \text { fsbk }\end{array}$ & sh & fi-fr & vsp, ps & $1 \mathrm{vf}$ & $\begin{array}{l}\mathrm{f}+\mathrm{vfv}, \\
2-1 \mathrm{mv}\end{array}$ & $\begin{array}{l}\text { 3-2f po } \\
\text { silans }+ \\
\text { argillans }\end{array}$ & $20-30$ & as-aw & none \\
\hline Btk1 & $10-31$ & $\begin{array}{l}7.5 \mathrm{YR} \\
6 / 4\end{array}$ & $\begin{array}{l}7.5 Y R \\
4 / 3\end{array}$ & $\mathrm{cl}$ & $\begin{array}{l}2 \mathrm{~m}+\mathrm{f} \\
\mathrm{abk}+\mathrm{sbk}\end{array}$ & h-sh & fi-fr & ss, p & $\begin{array}{l}1 \mathrm{vf}+ \\
\mathrm{v} 1 \mathrm{~m}\end{array}$ & $\begin{array}{l}1 \mathrm{vft}, \\
2 \mathrm{vfi}\end{array}$ & $\begin{array}{l}\text { 4f-p co } \\
\text { argillans }+ \\
\text { press face }\end{array}$ & $20-30$ & as-aw & non-e d, es, 4f-d,f co:bots \\
\hline Btk2 & $31-49$ & $\begin{array}{l}7.5 \mathrm{YR} \\
5 / 4 \\
\end{array}$ & $\begin{array}{l}7.5 Y R \\
4 / 3 \\
\end{array}$ & cl-sicl & $1-2 m+f$ sbk & sh & fr & ss, ps-p & $1 \mathrm{vf}$ & $2 v f t+i$ & $\begin{array}{l}4 \mathrm{f}-\mathrm{p} \text { pf } \\
\text { argillans }\end{array}$ & $20-30$ & cs & ve d, e, 2f-d,f,co:bots \\
\hline \multicolumn{15}{|c|}{ Site 3 [Soil No. NA8-2] - Undercanopy } \\
\hline $\mathrm{AC}$ & $0-6$ & $\begin{array}{l}10 \mathrm{YR} \\
5 / 2.5 \\
\end{array}$ & $\begin{array}{l}10 \mathrm{YR} \\
4 / 2 \\
\end{array}$ & sil-1 & $\begin{array}{l}\text { sg to } \\
\text { 1f sbk }\end{array}$ & lo-so & lo-vfr & ss, ps & $2 \mathrm{vf}, 1 \mathrm{f}$ & $\begin{array}{l}1-2 v f \\
I+t\end{array}$ & $\mathrm{NO}$ & $10-20$ & aw-cs & es d \\
\hline $\mathrm{C}$ & $6-17$ & $\begin{array}{l}10 \mathrm{YR} \\
6 / 3 \\
\end{array}$ & $\begin{array}{l}10 \mathrm{YR} \\
4 / 2 \\
\end{array}$ & sil & $\mathrm{sg}$ & lo & lo & ss, ps & $2 \mathrm{vf}, 1 \mathrm{f}$ & $1 \mathrm{vft}$ & $\mathrm{NO}$ & $10-20$ & aw-ai & none \\
\hline Av & $17-27$ & $\begin{array}{l}10 \mathrm{YR} \\
7 / 2 \\
\end{array}$ & $\begin{array}{l}10 \mathrm{YR} \\
4 / 3\end{array}$ & 1 & $\begin{array}{l}1 \mathrm{mpl}: \\
1 \mathrm{fsbk}\end{array}$ & sh-so & fr & ss, ps & NO & $\begin{array}{l}1 \mathrm{vft}, \\
2 \mathrm{vfv}\end{array}$ & $\mathrm{NO}$ & $5-10$ & aw-ai & ed \\
\hline Btk1 & $27-52$ & $\begin{array}{l}7.5 \mathrm{YR} \\
6 / 4\end{array}$ & $\begin{array}{l}7.5 Y R \\
4 / 3\end{array}$ & sacl & $\begin{array}{l}2 \mathrm{~m}+\mathrm{f} \\
\mathrm{abk}+\mathrm{sbk}\end{array}$ & h-sh & fi-fr & ss, $p$ & $\begin{array}{l}1 \mathrm{vf}+ \\
\mathrm{vfm}\end{array}$ & $\begin{array}{l}1 \mathrm{vft}, \\
2 \mathrm{vfi}\end{array}$ & $\begin{array}{l}\text { 4f-p co } \\
\text { argillans }+ \\
\text { press face }\end{array}$ & $20-30$ & as-aw & non-e d, e s, 4f-d,f co:bots \\
\hline Btk2 & $52-74$ & $\begin{array}{l}7.5 \mathrm{YR} \\
5 / 4\end{array}$ & $\begin{array}{l}7.5 Y R \\
4 / 3\end{array}$ & $\mathrm{cl}$ & $1-2 m+f$ sbk & sh & fr & ss, ps-p & $1 \mathrm{vf}$ & $2 \mathrm{vft}+\mathrm{i}$ & $\begin{array}{l}\text { 4f-p pf } \\
\text { argillans }\end{array}$ & $20-30$ & cs & ve d, e, 2f-d,f,co:bots \\
\hline
\end{tabular}

a: Genetic horizon. $\mathrm{O}=$ zone of decomposing organic litter, $\mathrm{A}=$ zone of organic matter accumulation, $\mathrm{B}=$ zone of weathering, $\mathrm{C}=$ parent material.

Suffix: $\mathrm{k}=$ accumulation of calcium carbonate, $\mathrm{j}=$ incipient development, $\mathrm{t}=$ accumulation of clay, $\mathrm{v}=$ vesicular pores, $\mathrm{w}=\mathrm{weak}$ oxidation and structure.

b: Munsell soil color.

c: Soil texture.

d: Soil structure.

e: Wet consistence as described by either stickiness between fingers or plasticity of rolled soil.

f: Surface coatings on pedfaces and clasts. silans = coatings of silt, argillans = coatings of clay.

g: Lower horizon boundary.

h: Carbonate morphology (disseminated, segregated). Typically as effervescence, distinctness, abundance, size and location.

NA: Not applicable

NO: Not Observed 
Table 7. Summary of measured soil properties.

\begin{tabular}{|c|c|c|c|c|c|c|c|c|c|}
\hline Horizon & Depth $(\mathrm{cm})$ & $\begin{array}{c}\% \\
\text { Gravel } \\
(\geq 2 \mathrm{~mm})\end{array}$ & $\begin{array}{c}\% \\
\text { Sand } \\
2-0.0625 \mathrm{~mm}\end{array}$ & $\begin{array}{c}\% \\
\text { Coarse Silt } \\
62.5-15 \mu \mathrm{m}\end{array}$ & $\begin{array}{c}\% \\
\text { Fine Silt } \\
15-3 \mu \mathrm{m}\end{array}$ & $\begin{array}{c}\% \\
\% \\
\text { Clay } \\
<3 \mu \mathrm{m}\end{array}$ & $\begin{array}{c}\% \\
\text { Silt }+ \text { Clay } \\
<62.5 \mu \mathrm{m}\end{array}$ & $\begin{array}{c}\mathrm{EC} \\
\mathrm{mg} / \mathrm{kg}\end{array}$ & $\begin{array}{c}\% \\
\mathrm{CaCO}_{3}\end{array}$ \\
\hline \multicolumn{10}{|l|}{ Site 1} \\
\hline \multicolumn{10}{|c|}{ Undercanopy [Soil No. NA3P-1] } \\
\hline $\mathrm{O}$ & $0-3+$ & ND & ND & ND & ND & ND & ND & NA & NA \\
\hline Ac & $0-10$ & 63 & 76 & 8 & 7 & 9 & 24 & 2,950 & 24 \\
\hline $\mathrm{C} 1$ & $10-46$ & 64 & 68 & 10 & 10 & 12 & 32 & 1,107 & 17 \\
\hline $\mathrm{C} 2$ & $46-118$ & 61 & 68 & 10 & 9 & 12 & 32 & 1,077 & 19 \\
\hline $\mathrm{C} 3$ & $118-238$ & 61 & 87 & 5 & 4 & 4 & 13 & 2,906 & 20 \\
\hline \multicolumn{10}{|l|}{ Site 2} \\
\hline \multicolumn{10}{|c|}{ Undercanopy [Soil No. NA3PC-2] } \\
\hline $\mathrm{O}$ & $0-4+$ & ND & ND & ND & ND & ND & ND & ND & ND \\
\hline $\mathrm{AC}$ & $0-11$ & 31 & 69 & 15 & 9 & 7 & 31 & 1,718 & 19 \\
\hline $\mathrm{BCk} / \mathrm{Avj}$ & $11-23$ & 28 & 72 & 14 & 8 & 7 & 28 & 893 & 20 \\
\hline BCk1 & $23-40$ & 43 & 80 & 10 & 6 & 5 & 20 & 768 & 24 \\
\hline BCk2 & $40-79$ & 65 & 88 & 5 & 4 & 3 & 12 & 793 & 26 \\
\hline Ck1 & $79-118$ & 73 & 85 & 4 & 4 & 6 & 15 & 1,621 & 29 \\
\hline \multicolumn{10}{|c|}{ Intercanopy [Soil No. NA3PC-1] } \\
\hline Av1 & $0-3$ & 52 & 69 & 18 & 8 & 5 & 31 & 713 & 10 \\
\hline Av2 & $3-8$ & 37 & 69 & 15 & 8 & 7 & 31 & 573 & 13 \\
\hline Bck-1 & $8-18$ & 58 & 66 & 14 & 9 & 11 & 34 & 693 & 15 \\
\hline $\mathrm{BCk} 2$ & $18-34$ & 71 & 81 & 9 & 6 & 4 & 19 & 756 & 23 \\
\hline Ck1 & $34-79$ & 70 & 91 & 4 & 3 & 2 & 9 & 757 & 17 \\
\hline Ck2 & $79-109$ & ND & ND & ND & ND & ND & ND & 984 & 22 \\
\hline \multicolumn{10}{|l|}{ Site 3} \\
\hline \multicolumn{10}{|c|}{ Undercanopy [Soil No. NA8-2] } \\
\hline $\mathrm{C} 1$ & $0-6$ & 23 & 49 & 13 & 17 & 21 & 51 & 1,167 & 1 \\
\hline $\mathrm{C} 2$ & $6-17$ & 25 & 51 & 14 & 16 & 19 & 49 & 887 & 2 \\
\hline Av & $17-27$ & 5 & 45 & 16 & 19 & 19 & 55 & 849 & 1 \\
\hline Btk1 & $27-52$ & 17 & 23 & 13 & 17 & 48 & 77 & 835 & 3 \\
\hline Btk2 & $52-74$ & ND & ND & ND & ND & ND & ND & ND & ND \\
\hline \multicolumn{10}{|c|}{ Intercanopy [Soil No. NA8-1] } \\
\hline Av & $0-10$ & 50 & 55 & 16 & 17 & 12 & 45 & 233 & 1 \\
\hline Btk1 & $10-31$ & 69 & 28 & 15 & 23 & 34 & 72 & 1,091 & 5 \\
\hline Btk2 & $31-49$ & 65 & 51 & 8 & 18 & 24 & 49 & 15,133 & 1 \\
\hline
\end{tabular}

\section{$\underline{\text { Analog Site } 1}$}

Soil No. NA3P-1

One soil profile below a shrub canopy of Mormon tea (Ephedra nevadensis) was described at this site (Figure $4 \mathrm{~b}$ ). The soil below the shrub has a 3 -cm O horizon consisting of a cover of poorly decomposed leaves and twigs from the overlying canopy. The uppermost soil horizon is a weakly developed AC horizon that has a weak blocky soil structure and a light accumulation of disseminated organic matter. The underlying $\mathrm{C}$ horizons have no soil structure and minimal evidence of pedogenic alteration except for localized mixing of the soil matrix due to bioturbation. The soil texture and soluble salt and carbonate content show no pedogenic modification and measured amounts reflect the soil used for fill material in construction of the pad (Table 6).

There are abundant signs of faunal and floral bioturbation in the soil cover of this construction pad (Figure 4b). The AC soil horizon is largely composed of soil material that 
has been excavated from below the canopy by burrowing mammals. This horizon forms a circular and conical mound of soil that extends slightly beyond the edge of the shrub canopy. Several open burrows 3 to $4 \mathrm{~cm}$ in diameter and 10 to $20 \mathrm{~cm}$ in length were exposed in the soil trench wall and several krotovina were also observed. Many of the shrubs on the construction pad also have open exit burrows (some exceeding $10 \mathrm{~cm}$ in diameter) at undercanopy soil surfaces. Root abundance ranged from few to common very fine and fine roots. Roots were present to the bottom of the soil trench at $238 \mathrm{~cm}$ depth.

\section{Analog Site 2}

Two soil profiles were described from a single trench excavated at this site. One soil profile (NA3PC-2) was described below a shrub canopy of white bursage (Ambrosia dumosa) and the other profile (NA3PC-1) underlies the intercanopy between shrubs. The two profiles are about $1.6 \mathrm{~m}$ apart.

\section{Soil No. NA3PC-1}

The soil in the intercanopy areas has two weakly developed Av horizons. These horizons are common to the desert soils in the southwestern U.S. and are formed from a longterm accumulation of aeolian fines (desert dust) below the soil surface (McFadden et al., 1998). The Avj1 and Avj2 have weak-to-moderate, platy-to-subangular blocky structure. The texture of these two Av horizons reflects the accumulation of dust, which has resulted in an increase in total silt and clay content relative to underlying horizons. Total silt and clay content is 31 percent weight in the Av horizons but is only 9 percent weight in the $\mathrm{C}$ horizon. The $\mathrm{C}$ horizon is considered to represent the general properties of the soil parent material (the material from which the soil formed). The BCk1 horizon is massive-to-weak, subangular blocky. The high silt and clay content of 34 percent weight in the BCk horizon indicates that this horizon has also accumulated at least some dust. The underlying BCk and $\mathrm{Ck}$ horizons are structureless. Pedogenic carbonate consists of coatings on the undersides of clasts and ranges from nearly continuous to patchy. Measured carbonate content of the less than 2-mm size fraction ranges from 10 to 23 percent weight and is highest in the BCk1 horizon. Soluble salt content ranges from 573 to $984 \mathrm{mg} / \mathrm{kg}$ and is highest in the $\mathrm{Ck} 2$ horizon.

Soil No. NA3PC-2

The undercanopy soil has a 4-cm O horizon consisting of a cover of poorly decomposed leaves and twigs from the overlying canopy (Figure 5b). The uppermost soil horizon is a weakly developed AC horizon that has weak, blocky soil structure and a light accumulation of disseminated organic matter. The AC horizon forms the soil mound that underlies the canopy and that has been built out over the existing soil surface. The BCk/Avj horizon is a mixed horizon that contains remnants of the Avj horizon (at one time at the soil surface) that has been buried by formation of the AC horizon. Most of the horizon appears to have been altered due to bioturbation and now has morphologic properties similar to a BCk horizon. The Avj remnants of this horizon are massive with weak, platy structure remaining in places. The Avj horizon in profile NA3PC-1 can be laterally traced into its position underlying the $\mathrm{AC}$ horizon in profile NA3PC-2. The structure in the BCk portions ranges from weak platy to massive. The underlying $\mathrm{BCk}$ and $\mathrm{Ck}$ horizons are structureless (single-grain to massive). Pedogenic carbonate consists of coatings on the undersides of clasts and ranges from nearly continuous to patchy. Measured carbonate content of the less than $2 \mathrm{~mm}$ size fraction ranges 
from 19 to 29 percent weight and is highest in the Ck1 horizon. Soluble salt content ranges from 768 to $1,718 \mathrm{mg} / \mathrm{kg}$ and is highest in the AC horizon.

Faunal and floral bioturbation has impacted the soil surface at this site. The undercanopy AC soil horizon is largely composed of soil material that has been excavated from below the canopy by burrowing mammals. This horizon forms a circular and conical mound of soil that extends slightly beyond the edge of the shrub canopy. Several large open burrows 4 to $8 \mathrm{~cm}$ in diameter and 15 to $30 \mathrm{~cm}$ in length were exposed in the soil trench wall. Root frequency and size range from few medium-size roots $(<5 \mathrm{~mm}$ diameter) to many fine to medium roots. Several large $(>5 \mathrm{~mm}$ diameter) shrub taproots were exposed elsewhere in the trench walls. Root frequency is highest below shrubs and root depth exceeds $118 \mathrm{~cm}$. The greatest concentration of roots is between 20 and $40 \mathrm{~cm}$ depth.

\section{Analog Site 3}

Two soil profiles were described from a single trench (Table 6). One soil profile (NA82 ) was described below a shrub canopy of blackbrush (Coleogyne ramosissima) and the other profile (NA8-1) underlies the intercanopy between shrubs (Figure 6). The two profiles are about $1.5 \mathrm{~m}$ apart. The significant paleosol observed at Site 3 was indicated by the presence of a Btk2 horizon at a depth of $52 \mathrm{~cm}$. Aeolian deposition, probably due to transport of finegrained material from the Yucca Flat Playa to the south, had been extensive and a welldeveloped Av horizon had formed in the buried paleosol.

Soil No. NA8-1

The soil in the intercanopy areas has a well-developed and thick (10-cm) Av horizon that has moderate-to-weak platy and subangular blocky structure. This horizon has formed from an extensive accumulation of desert dust. Being situated at the north end and at a slightly higher elevation than Yucca Flat probably contributes to significant aeolian deposition, particular when prevailing winds are seasonally from the south. The soil has a total silt and clay content of 45 percent weight, and has a loam texture. The intercanopy areas are covered with a moderately developed desert pavement that has a mosaic of interlocking clasts (Figure 6b). The soil has two Btk horizons that underlie the Av horizon. The Btk horizons have a noticeably redder soil hue, relative to soils at Analog Sites 2 and 1 (7.5YR versus 10YR hues), due to greater weathering of iron-bearing minerals. Total silt and clay content in the Btk horizons ranges from 72 to 49 percent weight, and the texture ranges from a clay loam to sandy clay loam. Argillans (coatings of translocated clay) are abundant in the Btk horizons. Carbonate content in this profile is low and ranges from 1 to 5 percent weight and is highest in the Btk1 horizon. Soluble salt content ranges from 233 to $15,133 \mathrm{mg} / \mathrm{kg}$ with the highest content in the Btk2 horizon.

\section{Soil No. NA8-2}

The undercanopy soil lacks a cover of poorly decomposed leaves and twigs from the overlying canopy. The uppermost soil horizon is a weakly developed AC horizon that ranges from weak, subangular blocky soil structure in places to structureless (single-grained) with a light accumulation of disseminated organic matter. The $\mathrm{AC}$ and underlying $\mathrm{C}$ horizon forms the mound that underlies the canopy and that has been built over the existing soil surface. The fine texture of the $\mathrm{AC}$ and $\mathrm{C}$ horizons indicates that the source of the soil matrix is from underlying soil that has been brought to the surface through bioturbation. The Av horizon is 
the original soil surface horizon (e.g., Av in NA8-1) that has been buried by development of the soil mound that underlies the shrub (Figure 6c). The Av has weak platy and subangular blocky structure, a silt loam texture, and a total silt and clay content of the buried Av horizon of 55 percent weight. The Av overlies two Btk horizons that have the same morphology as described in profile NA8-1. Total silt and clay content in the Btk horizons ranges from 55 to 77 percent weight. Carbonate content in this profile is low and ranges from 1 to 3 percent weight and is highest in the Btk2 horizon. Soluble salt content ranges from 835 to 1,167 $\mathrm{mg} / \mathrm{kg}$ with the highest content in the $\mathrm{C} 1$ horizon.

Faunal and floral bioturbation have impacted the soil surface at Site 3. The AC and C horizons that underlie the shrub canopy are largely composed of soil material that has been excavated from below the canopy by burrowing mammals. This horizon forms a circular and conical mound of soil that extends slightly beyond the edge of the shrub canopy. Several large open burrows 8 to $12 \mathrm{~cm}$ in diameter and 15 to $30 \mathrm{~cm}$ in length were exposed in the soil trench wall and several 5- to $10-\mathrm{cm}$-diameter krotovina are also exposed. Root frequency and size range from very fine to common, very fine roots. Root frequency is highest below shrubs and root depth exceeds $75 \mathrm{~cm}$. The greatest concentration of roots is between 10 and $50 \mathrm{~cm}$ depth.

A dark desert varnish is on the exposed surface of the naturally occurring rocks and the obsidian is dull on the exposed surface. Desert varnish on the obsidian is further evidence that the sites and the material have remained intact and that they have not been transported to the area or disturbed recently by processes such as sheet flow. Desert pavement is moderately well developed at the site, although the sorting and alignment of clasts is not as well developed as at Site 4.

\section{Soil Hydraulic Properties}

In total, 48 tension infiltrometer tests were conducted at the primary analog sites. Each location was also sampled for bulk density, final volumetric water content, and particle-size analysis. In a few cases, instrument failure did not allow completion of tests, reducing the number of replicates, or time was found to measure more than three locations at a given treatment. In the latter cases, the measurement results were included in the calculation of the mean. The addition of sampling locations should not impact the results, however, because the undercanopies and intercanopies at each soil surface are being treated as replicates. Table 8 shows the locations and number of tests conducted at each site. In some cases, sample bags leaked either some fluid or soil after completing the tests, and some professional judgment was made regarding the usefulness of those samples for bulk density and water content. In the latter case, final water content was used mainly as a fitting variable in the parameter estimation. These water content data were used mostly as a starting point in the simulation, and were not critical to final fitted parameter sets.

Results of soil texture are found in Table 9, and they show an increase in fines (silt + clay) content as the soils aged, for both the intercanopy and undercanopy areas. The results are consistent with McDonald et al. (2003) and Young et al. (2003) for pavement surfaces at the Mojave National Preserve, in which increases in fines could be attributed to pedogenic development of the soil surface. The sand content in the undercanopies was consistently higher than in the intercanopy areas, promoting higher infiltration. One explanation for the 
Table 8. Breakdown of the location and number of field tests conducted for hydraulic property analyses. Numbers are split across two paired locations of undercanopy/intercanopy, with a goal of triplicate measurements at each location.

\begin{tabular}{cccccc}
\hline Location & $\begin{array}{c}\text { Infiltrometer - } \\
\text { Wooding's analysis }\end{array}$ & $\begin{array}{c}\text { Infiltrometer - } \\
\text { HYDRUS-2D analysis }\end{array}$ & $\begin{array}{c}\text { Volumetric } \\
\text { water content }\end{array}$ & $\begin{array}{c}\text { Bulk } \\
\text { density }\end{array}$ & $\begin{array}{c}\text { Particle-size } \\
\text { analysis }^{\sharp}\end{array}$ \\
\hline Site 1 - IC & 8 & 8 & 4 & 5 & 8 \\
Site 1 - UC & 5 & 6 & 6 & 6 & 5 \\
Site 2 - IC & 7 & 7 & 7 & 7 & 6 \\
Site 2 - UC & 5 & 5 & 4 & 3 & 6 \\
Site 3 - IC & 6 & 6 & 5 & 5 & 6 \\
Site 3 - UC & 4 & 4 & 7 & 6 & 6 \\
Site 4 - IC & 6 & 6 & 8 & 6 & 6 \\
Site 4 - UC & 6 & 6 & 8 & 6 & 6 \\
\hline
\end{tabular}

Notes: $\uparrow$ - IC = Intercanopy; $\$$ - UC = Undercanopy; $\uparrow$ - Numbers include initial samples collected before tests were conducted.

Table 9. Average \pm standard deviation for textural components of material sampled at intercanopy and undercanopy areas. Year refers to the midpoint age range of the soil. Gravel fraction is the weight percent of the entire sample $>2 \mathrm{~mm}$. The remaining textural analysis involves only the fine-earth fraction $(<2 \mathrm{~mm})$.

\begin{tabular}{|c|c|c|c|c|}
\hline Intercanopy & & & & \\
\hline Year & $\%$ Gravel $^{1}$ & $\%$ Sand $^{2}$ & $\% \mathrm{Silt}^{3}$ & $\%$ Clay $^{4}$ \\
\hline 30 & $49.3 \pm 5.2$ & $79.7 \pm 6.0$ & $14.5 \pm 1.9$ & $5.8 \pm 2.5$ \\
\hline 1,000 to 2,000 & $35.8 \pm 7.8$ & $80.2 \pm 3.0$ & $14.2 \pm 0.5$ & $5.7 \pm 2.4$ \\
\hline 7,000 to 12,500 & $55.6 \pm 17.7$ & $55.6 \pm 6.0$ & $28.3 \pm 2.6$ & $16.1 \pm 1.9$ \\
\hline 125,000 & $31.6 \pm 21.0$ & $50.6 \pm 3.9$ & $34.1 \pm 1.7$ & $15.3 \pm 3.8$ \\
\hline \multicolumn{5}{|l|}{ Undercanopy } \\
\hline Year & $\%$ Gravel $^{1}$ & $\%$ Sand $^{2}$ & $\% \mathrm{Silt}^{3}$ & $\%$ Clay $^{4}$ \\
\hline 30 & $38.6 \pm 7.8$ & $84.1 \pm 3.0$ & $10.9 \pm 1.1$ & $5.0 \pm 1.2$ \\
\hline 1,000 to 2,000 & $33.0 \pm 13.4$ & $80.7 \pm 2.8$ & $15.6 \pm 1.1$ & $3.7 \pm 0.8$ \\
\hline 7,000 to 12,500 & $26.4 \pm 7.9$ & $65.1 \pm 5.0$ & $23.0 \pm 1.6$ & $11.9 \pm 5.4$ \\
\hline 125,000 & $27.2 \pm 12.6$ & $70.4 \pm 8.0$ & $23.0 \pm 2.8$ & $6.6 \pm 2.6$ \\
\hline
\end{tabular}

${ }_{0} \%$ Gravel is representative of the total sample $>2 \mathrm{~mm}$.

${ }^{2} \%$ Sand of the fine-earth fraction ranging from $62.5 \mu \mathrm{m}$ to $2,000 \mu \mathrm{m}$.

${ }^{3} \%$ Silt of the fine-earth fraction ranging from $3 \mu \mathrm{m}$ to $62.5 \mu \mathrm{m}$.

${ }^{4} \%$ Clay of the fine-earth fraction $<2 \mu \mathrm{m}$.

sandier texture could be that bioturbation near the soil surface was continually mixing the soil, where wind entrainment carried the finer-grained materials away from the canopy area, resulting in higher proportions of sand in the soil matrix. We note that the silt and clay content at Site 3 is slightly less than at Site 4, which is inconsistent with our hypothesis that pedogenic development increases the fines content. One explanation for this is that Site 3 is at the northern end of Yucca Flat, and likely receives more aeolian deposition. As will be discussed below, the higher silt and clay content of the soil will impact water flow and storage in the near-surface soil. 
Table 10 lists the results of Wooding's analysis, specifically $\mathrm{Ksat}_{\mathrm{w}}$ and $\alpha_{\mathrm{w}}$ that are obtained when using tension and cumulative outflow as input variables. Note that these two variables were log-transformed prior to averaging, to account for the log-normal distributions that they are known to exhibit (White and Sully, 1992; Mohanty and Mousli, 2000). Saturated hydraulic conductivity fell by five times when spanning different soils in the intercanopy area only. This trend of decreasing $\mathrm{Ksat}_{\mathrm{w}}$ was also seen in soils at the Mojave National Preserve (Young et al., 2003), but the amount of decline was less at the NTS sites. Different source materials at the NTS study sites could partially explain the differences. No real trend was seen in the undercanopy area, even with the increased percentage of fines with aging. Many of the undercanopies tested showed signs of being either active or abandoned with respect to animal burrows, and the intersection of the wetting front with the macropores created by burrowing mostly likely occurred, which could explain some of the variability. Though the textural data can explain some of the inconsistencies, water retention and conductivity functions are greatly affected by the soil structure in wet soils (Hillel, 1998), and the bioturbation in undercanopy areas greatly reduces the structure in soil horizons.

Table 10. Results of field analyses of hydraulic properties at the four analog sites. Ksat and alpha parameters are represented as geometric mean. Other parameters are arithmetic mean.

\begin{tabular}{|c|c|c|c|c|c|c|}
\hline \multicolumn{7}{|c|}{ Wooding's Analysis - Intercanopy } \\
\hline & $\begin{array}{l}\sim \text { Age } \\
\text { (years) }\end{array}$ & $\begin{array}{l}\mathrm{Ksat}_{\mathrm{w}} \\
(\mathrm{cm} / \mathrm{d})\end{array}$ & $\begin{array}{c}\alpha_{\mathrm{w}} \\
\left(\mathrm{cm}^{-1}\right)\end{array}$ & $\mathrm{R}^{2}$ & & \\
\hline & 30 & 119.12 & 0.268 & 0.951 & & \\
\hline & 1,000 to 2,000 & 87.95 & 0.133 & 0.948 & & \\
\hline & 7,000 to 12,500 & 66.56 & 0.181 & 0.930 & & \\
\hline & 125,000 & 25.27 & 0.123 & 0.961 & & \\
\hline \multicolumn{7}{|c|}{ Wooding's Analysis - Undercanopy } \\
\hline & $\begin{array}{l}\sim \text { Age } \\
\text { (years) }\end{array}$ & $\begin{array}{l}\mathrm{Ksat}_{\mathrm{w}} \\
(\mathrm{cm} / \mathrm{d})\end{array}$ & $\begin{array}{c}\alpha_{\mathrm{w}} \\
\left(\mathrm{cm}^{-1}\right)\end{array}$ & $\mathrm{R}^{2}$ & & \\
\hline & 30 & 75.01 & 0.313 & 0.961 & & \\
\hline & 1,000 to 2,000 & 147.18 & 0.260 & 0.940 & & \\
\hline & 7,000 to 12,500 & 55.13 & 0.180 & 0.887 & & \\
\hline & 125,000 & 81.01 & 0.251 & 0.950 & & \\
\hline \multicolumn{7}{|c|}{ HYDRUS-2D Analysis - Intercanopy } \\
\hline $\begin{array}{c}\sim \text { Age } \\
\text { (years) }\end{array}$ & $\theta \mathrm{s}$ & $\begin{array}{c}\alpha_{\mathrm{vg}} \\
\left(\mathrm{cm}^{-1}\right)\end{array}$ & $\mathrm{n}$ & $\begin{array}{l}\mathrm{Ksat}_{\mathrm{vg}} \\
(\mathrm{cm} / \mathrm{d})\end{array}$ & $\begin{array}{l}1 / \alpha \\
(\mathrm{cm})\end{array}$ & $\mathrm{R}^{2}$ \\
\hline 30 & 0.262 & 0.137 & 1.495 & 280.02 & 7.29 & 0.997 \\
\hline 1,000 to 2,000 & 0.269 & 0.060 & 2.522 & 86.98 & 16.58 & 0.999 \\
\hline 7,000 to 12,500 & 0.304 & 0.086 & 1.753 & 109.10 & 11.59 & 0.999 \\
\hline 125,000 & 0.215 & 0.064 & 2.454 & 27.95 & 15.56 & 0.998 \\
\hline \multicolumn{7}{|c|}{ HYDRUS-2D Analysis - Undercanopy } \\
\hline $\begin{array}{c}\sim \text { Age } \\
\text { (years) }\end{array}$ & $\theta \mathrm{s}$ & $\begin{array}{c}\alpha_{\mathrm{vg}} \\
\left(\mathrm{cm}^{-1}\right)\end{array}$ & $\mathrm{n}$ & $\begin{array}{l}\mathrm{Ksat}_{\mathrm{vg}} \\
(\mathrm{cm} / \mathrm{d})\end{array}$ & $\begin{array}{l}1 / \alpha \\
(\mathrm{cm})\end{array}$ & $\mathrm{R}^{2}$ \\
\hline 30 & 0.318 & 0.204 & 1.378 & 392.74 & 4.90 & 0.997 \\
\hline 1,000 to 2,000 & 0.397 & 0.182 & 1.471 & 131.16 & 5.50 & 0.997 \\
\hline 7,000 to 12,500 & 0.316 & 0.127 & 1.586 & 275.88 & 7.87 & 0.998 \\
\hline 125,000 & 0.341 & 0.102 & 1.713 & 398.77 & 9.82 & 0.999 \\
\hline
\end{tabular}


The results also showed that $\alpha_{\mathrm{w}}$ tended to decrease with increasing age, though not consistently. Functionally, a more rapid decline could be caused by either larger pore classes that drain more readily under gravity, or soil water hydrophobicity (Ritsema et al., 1993; Yang et al., 1996). The decline of $\alpha_{\mathrm{w}}$ in the plant undercanopy areas was not as consistent as the intercanopy, indicating that soils in the intercanopy area became less permeable with age, and that they drained less readily as well.

A typical graph of observed data from the infiltrometer and simulated response from HYDRUS-2D is shown in Figure 16. The graphs, one each for the intercanopy and undercanopy sites, show good agreement between the observed and predicted responses. Inflections on the graphs reflect times when the tensions are manually reset on the infiltrometer, and the model was able to identify those times quite well. Some fluctuations in the observed data on Figure $16 \mathrm{~b}$ are from increased temperatures that occur near solar noon. Data collected from experiments conducted earlier that day (Figure 16a) show very stable output. Coefficients of determination (i.e., $\mathrm{R}^{2}$ ) from the modeling, which can be used as a measure of success in the inversion routine, ranged from 0.98578 to 0.99988 , with an overall mean of 0.99830 .

Table 10 also shows the results of the numerical inversion simulations. One significant advantage of using HYDRUS-2D, instead of the semi-empirical Wooding's equation, is that water retention functions can also be estimated. The parameters $\theta_{\mathrm{s}}, \alpha_{\varpi \gamma}$, and $\mathrm{n}$ are related to the retention curve through Equations (3) and (4), and can be estimated when pressure transducers are used during data collection. Similar to results from Wooding's analysis, the saturated hydraulic conductivity $\mathrm{Ksat}_{\mathrm{vg}}$ showed a reducing trend with age in the intercanopy area, but not for the undercanopy sites. Several items with respect to the inversion results are of particular importance. First, the order of magnitude decrease in $\mathrm{Ksat}_{\mathrm{vg}}$ in the intercanopy areas is larger than estimated using Wooding's analysis. The lack of sensitivity of Ksat ${ }_{\mathrm{vg}}$ in the undercanopy can be attributed to the bioturbation of the near-surface soils, disrupting the soil layering and preventing the creation of the vesicular Av horizon. Second, the magnitude of the $\mathrm{Ksat}_{\mathrm{vg}}$ is much lower overall in the intercanopies versus the undercanopies, likely because of the disruption of the soil structure, and the significant role that structure plays in the overall behavior of hydraulic conductivity. From a plant ecosystem standpoint, bioturbation from animal burrowing and plant roots may be a critical process that prevents armoring of the soil surface under canopies and allows precipitation to percolate more deeply into the areas immediately adjacent to the root mass. Finally, it appears that pedological development had some impact on the air entry pressure in the soil, which is approximately equal to the reciprocal of $\alpha_{\mathrm{vg}}$. The higher air entry pressure in the intercanopy area indicates the more aggregated nature of the soil, and the relative lack of macropores that would transmit large quantities of water at near-saturated conditions. The presence of root channels and faunal burrows (e.g., mammals and/or insects) below the plant canopies could explain the lower air entry pressure and the larger macropores present near the soil surface.

Age, and the aeolian deposition of fines in this environment and at these sites, led to a reduced saturated hydraulic conductivity of the uppermost soil layer. Figure 17 shows that the relationship of Ksat and soil age when represented on a log-log plot using both the semiempirical (Wooding's) and parameter estimation (HYDRUS-2D) approaches. Though it is clear that some scatter is present on both graphs, both methods show a linear decline in Ksat with time for the intercanopy areas, and virtually no trend with time in the undercanopy 

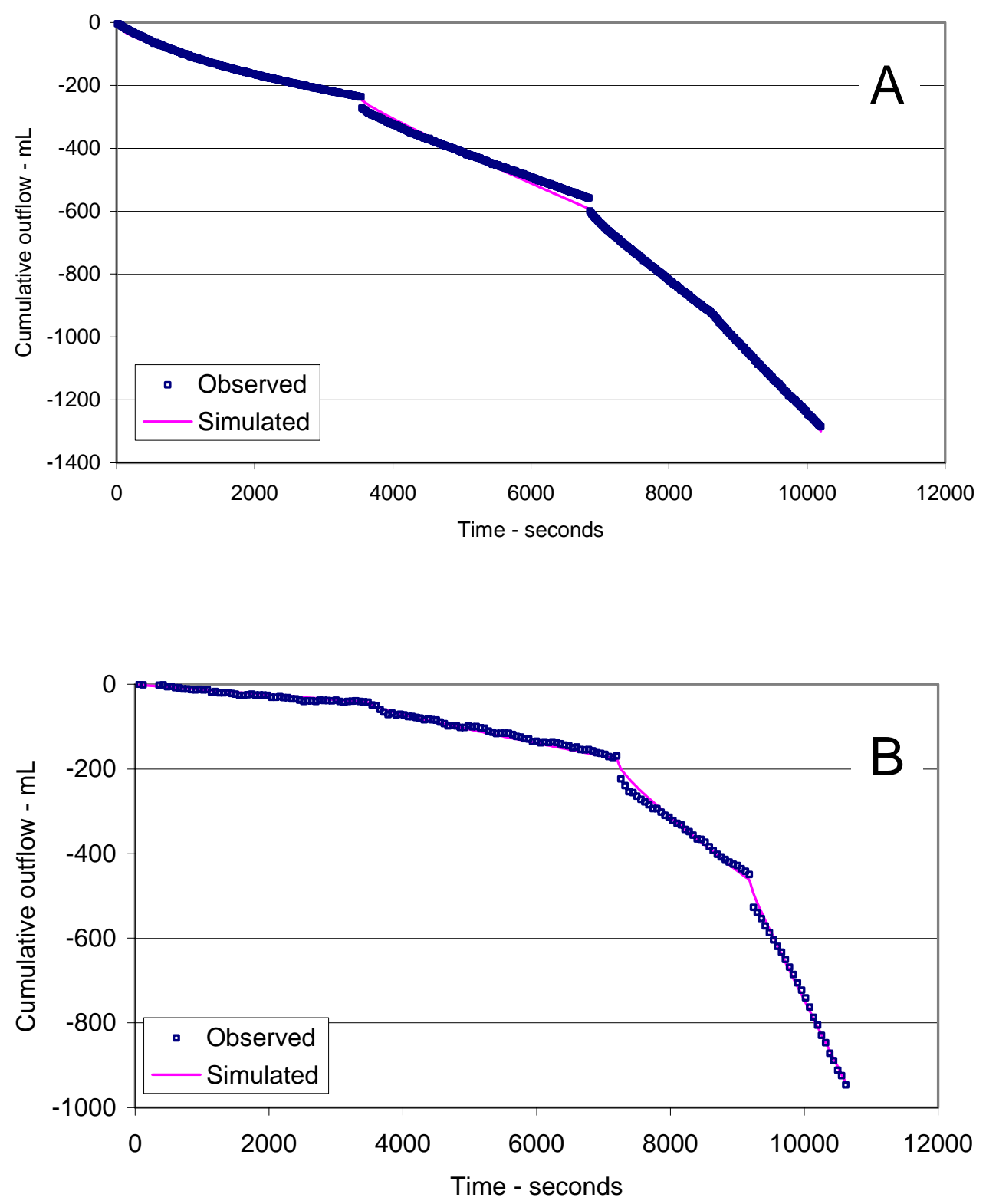

Figure 16. Graphs showing representative observed and simulated responses from tension infiltrometer and HYDRUS-2D model, respectively, for Site 4, intercanopy (A) and undercanopy (B) sites. 

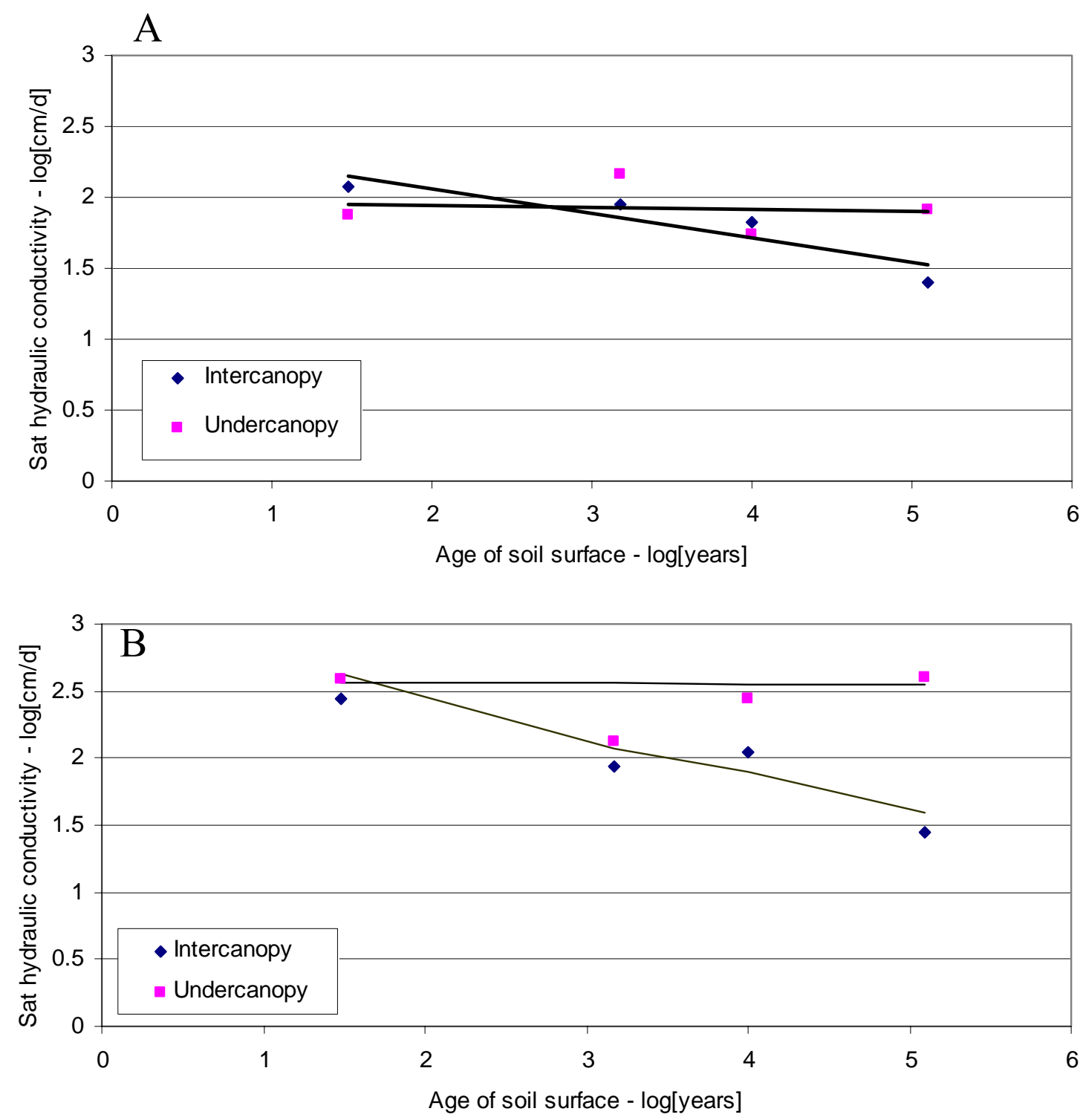

Figure 17. Geometric means of Ksat using semi-empirical (A) (Wooding's) and parameter estimation (B) (HYDRUS-2D) methods, for intercanopies and undercanopies. Regression models are shown as solid lines.

areas. From a waste management cover perspective, the reduction in hydraulic conductivity with surface age means that allowing the soil structure to develop over time could reduce the deep percolation that might occur over broader areas of the cover. Further, though the conductivity is reduced, this does not translate directly into higher surface runoff (and consequent erosion). In this case, the lowest Ksat was estimated to be between 25 and 81 $\mathrm{cm} / \mathrm{d}$, depending on the analytical approach, still high enough to allow water entry for most storms likely to be experienced at the NTS. Though water movement through disposal covers is often viewed negatively, plant transpiration will likely remove the vast majority of percolate, and not impact any components of the deeper water balance. 


\section{CONCLUSIONS}

The data and discussions in this report suggest that ET covers - essentially disturbed land surfaces - evolve over time, potentially yielding stable soils surfaces and viable waste disposal covers. Flora and faunal activities correlate to changes in soil surface, where it is clear that bioturbation processes contributed to soil development. Other researchers have made similar findings (cf. Hammerlynck et al., 2002) in the Mojave Desert, and in other semi-arid sites (Eagleson, 2002). While many of these processes are truly coupled and difficult to discuss separately, the following are some of the most significant processes that may potentially change ET covers based on the sites studied herein.

\section{Deposition of Fines and Development of Soil Structure}

Eolian deposition of fines may be the most significant long-term process that will affect ET covers over time in this region. The results of the textural analyses suggest a relationship between soil age and relative proportions of sand, silt, and clay. Other sites downwind of source areas, like Yucca Playa, for example, would also be expected to experience soil textural changes with time. Heavier textured soils (i.e., those with higher proportions of silt and clay) also have increased water-holding capacities, because silt and clay particles have higher surface areas, and more water adsorption onto these surfaces can occur. Heaviertextured surface soils keep water closer to ground surface and available for evaporation (Hillel and van Bavel, 1976; Hillel, 1998), and reducing the depth of percolation for a given precipitation event, because of the higher soil-water deficit.

However, age alone does not entirely explain the degree of soil development. For example, Primary Analog Sites 3 and 4 show similar percentages of silts and clays from aeolian deposition, and the development of the vesicular Av horizon in the near-surface horizons. The position of Analog Site 3 at the north end of Yucca Flat means that it is ideally situated geographically for aeolian deposition of material derived from playas to the south, especially during that part of the year when prevailing winds are from the south-southwest (Figure 3).

\section{Progressive Decrease in Infiltration and Saturated Hydraulic Conductivity}

One of the trends most clearly tied to performance objectives of ET covers in the Integrated Closure and Monitoring Plan (Bechtel Nevada, 2001) is a fivefold decrease in Ksat in intercanopy areas as measured from the youngest analog site soils to the oldest. Wooding's analysis also showed a linear decrease with time in saturated hydraulic conductivity in intercanopy areas, but the data were more variable in undercanopy areas. The aeolian deposition of fines and the development of soil structure are likely the factors most responsible for the large decrease in intercanopy areas. In undercanopy areas, the limited decrease in Ksat is hypothesized to be due to bioturbation of near-surface soil, and particularly the disruption of the Av horizon.

The results of the analog research on the NTS are similar to findings by Young et al. (2003) in the Providence Mountains of the Mojave National Preserve that showed a similar trend but with a larger degree of change (two orders of magnitude) with time for undercanopy areas. 


\section{Development of Desert Pavements on Covers}

One of the diagnostic features of desert pavements is the presence of clasts at the soil surface. These clasts are typically one to two layers thick, closely packed, and of variable diameter. Among other influences on the ecosystem, the clasts armor the soil and reduce the potential for aeolian degradation as well as sheet erosion. In some case, depending on the local topography, the surface clasts increase the roughness of the soil surface, which can reduce the air velocity near the soil surface, depositing entrained fines. As described above, the deposition of fines in the upper soil impacts water movement and plant uptake for several reasons. The clasts themselves originate in the parent material and are physically moved from their source through erosion and mass wasting processes, eventually migrating upward through a number of physical processes, including bioturbation (McDonald et al., 2003).

The accumulation at the surface of coarser clasts from bioturbation could be an early stage in the development of a desert pavement. The bioturbation processes can promote the development of armoring and deposition of fines, if the gravel or clast material is present in the soil profile, and promote stability and inhibit erosion and abrasion of the cover. However, as indicated by the primary analog sites, such a scenario would only occur if coarser clasts are in the upper $70 \mathrm{~cm}$ (no active burrows or krotovina were observed in trenches below this depth).

\section{Degree of Vegetation Cover and Desert Pavement Formation}

Compared to more mesic environments, it is easy to overestimate the density of native vegetation that would be expected to become established on covers. Based on the four primary analog sites evaluated, vegetation cover peaked at about 35 percent at Site 3 and actually decreased at Site 4, where the desert pavement was best established. The decision at the U3axbl landfill to seek an initial vegetation density of approximately 60 percent would not have been sustainable, with or without the ongoing drought.

The four primary analog sites exhibit a trend of decreasing percent cover as the degree of desert pavement development increases. Such trends are exhibited elsewhere, such as at Yuma Proving Ground in Arizona and in the Providence Mountains in the Mojave National Preserve (Hammerlynk et al., 2002; McDonald et al., 2003). Particularly for waste disposal sites where a 10,000-year compliance period could be required, the development of desert pavement could replace part of the role of vegetation in stabilizing the surface of the cover. Though spatial variability makes it difficult to generalize on the time needed to create desert pavements under completely natural conditions, about 5,000 years would be needed for the development of a moderate pavement, and about 10,000 years minimum for the development of a well-developed pavement surface (McDonald et al., 2003) such as indicated by Primary Analog Site 3.

\section{Development of 'Fertile Islands' on Covers}

The high correlation between the occurrence of animal burrows and perennial shrubs on the primary analog sites is probably the best evidence in this study of the development of what are generally referred to as "fertile islands" in desert ecosystems (Bolling and Walker, 2002). In the Mojave and other deserts, micro- and macro-fauna are attracted to the canopy of whatever plants become established as locales of lower day-time temperatures and the

most abundant food sources. As leaf litter accumulates and animal burrowing occurs, the 
fertile island shrubs become increasingly favorable sites compared to intercanopy sites because of factors such as 1) decreased bulk density of soils, greater water infiltration and soil water retention, factors also observed in this study; and 2) greater cycling of soil nutrients, particularly nitrogen $(\mathrm{N})$ and phosphorus $(\mathrm{P})$, elements generally considered most limiting to plant growth in arid regions (Schlesinger et al., 1996; Whitford and Kay, 1999). In contrast, intercanopy areas impose greater abiotic stress because of their higher irradiance and surface temperatures, lower nutrient availability, and, consistent with results of this study, reduced infiltration by water (Housman et al., 2003).

Overall, the fertile-island phenomenon, which couples flora, fauna and soil, is a process favorable to the long-term performance of ET covers, although for two, seemingly contrary reasons. The first is that the fertile islands and their associated shrubs become less susceptible to short-term fluctuations in precipitation, and more resistant to long-term droughts or other events that change resource availability. Further, the concentration of N, in particular, allows plants to optimize the water that is available (Garner and Steinberger, 1989; Reynolds et al., 1999). In short, the fertile-island process increases the probability of ET covers maintaining effective vegetation for transpiration.

The second effect of fertile islands to the long-term performance of ET covers is that, while fertile islands function to concentrate nutrients and others resources around them, they also becoming "staging points" for transport of nutrients and establishment of recruitment plants in intercanopy areas. For example, while small mammals and other animals seek the shelter of the fertile islands, their foraging activities can take them into intercanopy areas. Rodents may dig shallow pits searching for, or creating, seed caches. Besides the transport of seeds or other leaf-litter material, animal feces, urine, and tissue are deposited. Particularly when these occur in small depressions (often created by the animal themselves), there can be local areas of focused infiltration during precipitation events and the entrapment of clay and silt-size particles, all of which create favorable conditions for germination of seedlings. Litter transport by wind from the plant mounds around the fertile islands, that also benefit this process, may also occur.

The best example observed during the course of this study is intercanopy burrowing first observed at Primary Analog Site 1 in October 2002. Small mammals had burrowed to as

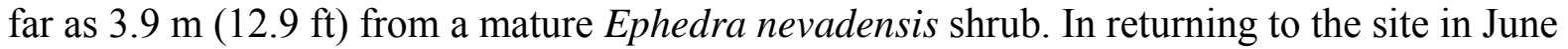
2003, many of the burrows had collapsed, creating depressions 7 to $9 \mathrm{~cm}$ (2.7 to 3.5 in) wide and 4 to $5 \mathrm{~cm}$ (1.6 to 2.0 in) deep (Figure 18). Many of these depressions had become sites where wiregrass (Ventenata dubia), a native perennial, had germinated. At the Nevada Free Air Carbon Dioxide Experiment Facility (FACE) in Frenchman Flat near the Area 5 RWMS, various species of Astragalous (common name, "locoweed") have germinated in similar shallow depressions. 


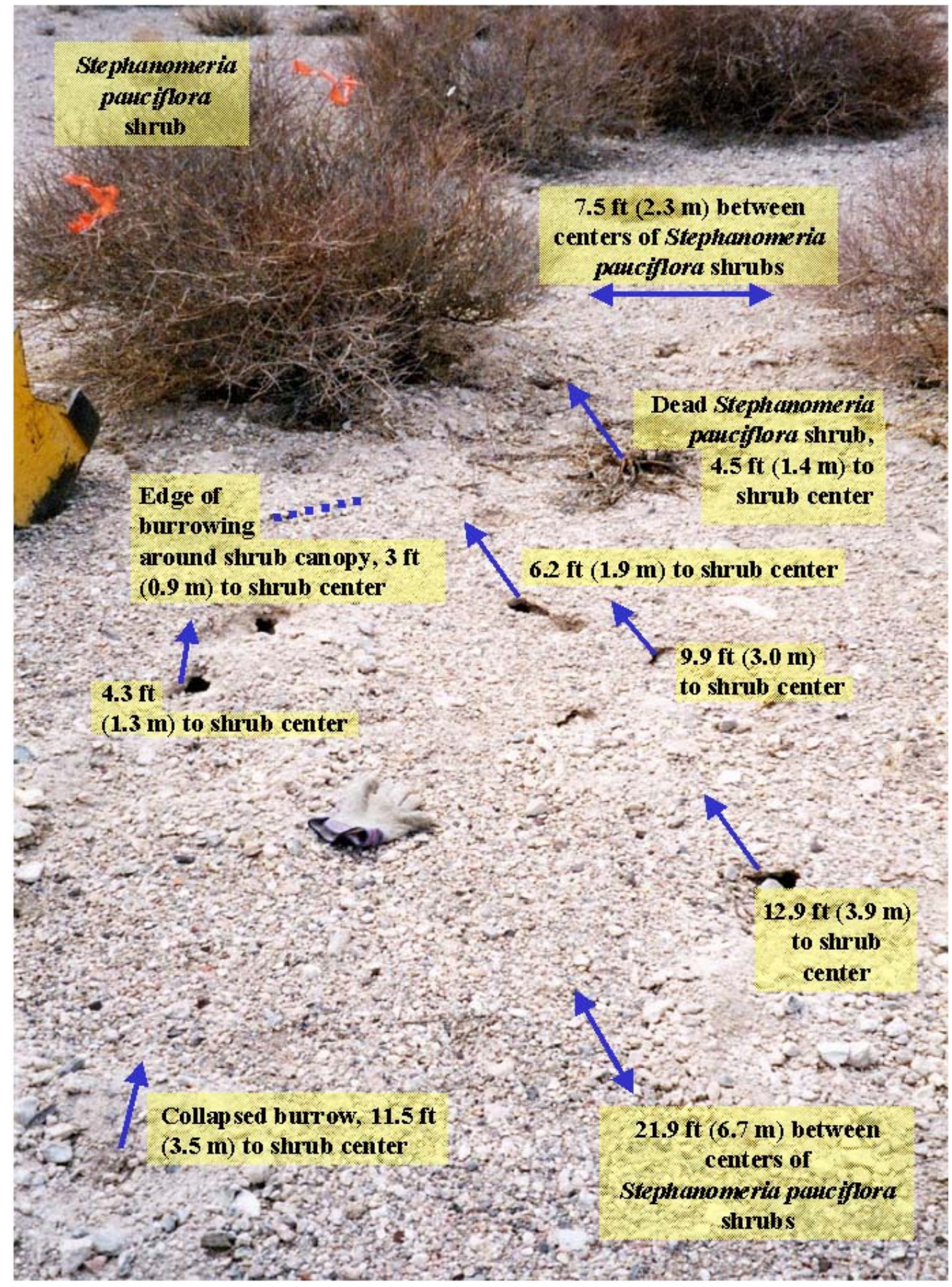

Figure 18. Locally, during the winter of calendar year 2002 to 2003, intercanopy burrowing by small mammals was extensive. Collapsed burrows were favorable sites for germination of seedlings of wire-lettuce (Stephanomeria pauciflora), a short-lived, native perennial, during spring 2003. 


\section{Species Composition for Initial Vegetation Establishment on ET Covers}

The proximity of native vegetation to an RWMS cover site may be a guide to what plants could be used to vegetate a cover, but the properties of soils of the natural surface need to be considered as well. For example, there is relatively low similarity of the species composition of Primary Analog Site 1 compared to Site 4, even though the sites are less than $100 \mathrm{~m}$ apart. More important than the proximity of native plants for recruitment to Site 1 was the ability of native plants that naturally colonize disturbed sites in the region to colonize Site 1. In the case of the U3axbl landfill, a native seed mix was developed for revegetation of the surface based on plants established on nearby distal fan deposits (Bechtel Nevada, 2002). However, visual inspection of the borrow source material used to construct the cover indicates that the U3axbl cover is considerably finer-grained compared to distal alluvial fan deposits such as found at Analog Site 2. Moreover, Secondary Analog Site A (UTM $0589812 \mathrm{E} 4100805 \mathrm{~N}$; elevation 1,208 m (3,964 ft)) south of the Area $3 \mathrm{RWMS}$, may be more indicative of the types of plants that could become established on the current topmost soil material at the U3axbl cover (Shafer et al., 2002). Secondary Analog Site 1 was "disturbed" as part of the underground nuclear testing program as equipment was "skidded" between different ground zero sites in Yucca Flat (Figure 19). Although there may have been periodic vehicle traffic across the site since, its last significant disturbance was in 1973. As such, this secondary site also provides an analog for an early post-institutional control period for a cover of fine-grained material such as that used in the construction of the U-3axbl ET cover. A thin layer of pea gravel, probably placed on the surface during construction to help stabilize it, overlies fine-grained aeolian material.

Although this site is approximately the same age (30 years) as Primary Analog Site 1, native plant recruitment is sparse. Native plants include Indian ricegrass (Achnatherum hymenoides), Eriogonum sp., skeleton weed (Eriogonum deflexum), and four-winged saltbush (Atriplex canescens). More common are exotic plants, particularly halogeton (Halogeton glomeratus), and cheat grass (Bromus sp.). These exotics as well as Russian thistle (Salsola iberica) are of limited value for transpiration, but have become pervasive in colonizing fine-grained, disturbed sites (and in this context, a new cover would be a disturbed site) in the Mojave and Great Basin (Hunter, 1991). Data herein also suggest that the significant encroachment of introduced or exotic winter annual plant species, especially Bromus madritensis, has taken place on the two youngest analog sites. Though this phenomenon may actually increase potential ET during a portion of the year, it may also have negative impacts on future recruitment of native perennial plants species essential for maintaining an acceptable level of ET for periods longer than 1,000 years.

\section{ADDITIONAL RESEARCH}

Besides insights into how ET covers could change over time, this research provides information, but raises additional questions, about processes of environmental change in the Mojave Desert. Some of the additional research that would be most pertinent to predicting the long-term performance of ET covers and environmental change in the Mojave Desert include the following: 


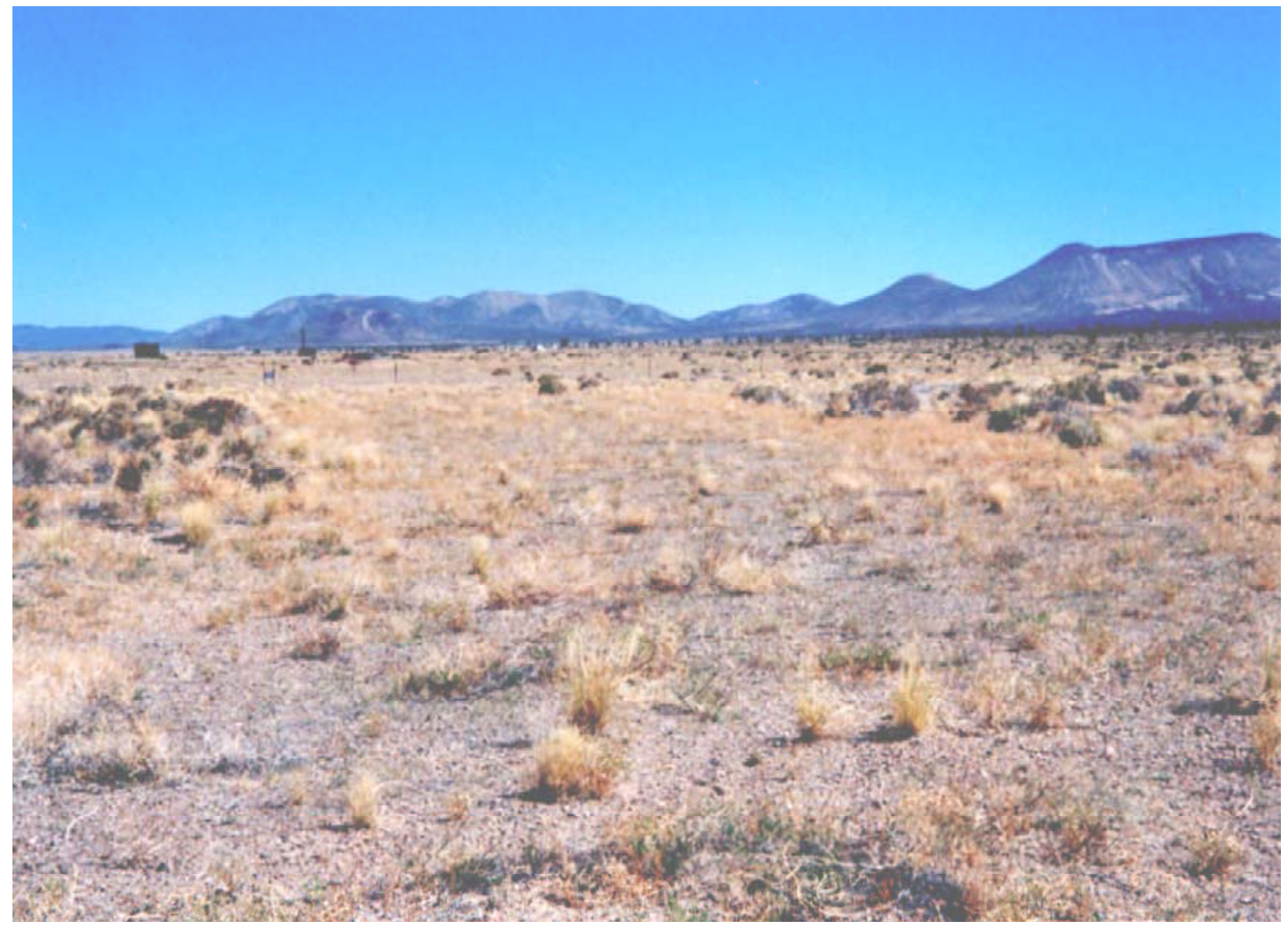

Figure 19. Secondary Analog Site A is on the floor of Yucca Flat south of the Area 3 RWMS. Although it was last disturbed in 1972 or 1973, compared to Primary Analog Site 1, natural recruitment of native plants has been sparse. However, exotic annuals are common on the site.

\section{Impacts of Burrowing Insects}

Based on studies at other DOE sites in the western U.S., concern about insect burrowing transferring soil material between layers and even the translocation of radiological waste material to the surface at the NTS is warranted. At the Hanford Site in Washington state, Fitzer et al. (1979) provided evidence that the harvester ant (Pogonomyrmex owyheei) was excavating soil from tunnels extending from 2 to $3 \mathrm{~m}$ depth in the Area 300 Burial Grounds. In addition, $P$. owyheei shows a preference for establishment in disturbed areas such as waste disposal sites. Blom et al. (1991) evaluated similar pathways in radionuclide waste sites at what is now known as the Idaho National Engineering and Environmental Laboratory by the harvester ant, $P$. salinus. DRI has proposed field investigations with Neptune and Company, Inc. to help validate this aspect of performance assessments for the RWMS at the NTS (Hooten et al., 2001) and its revisions (Hooten, personal communication, 2003).

\section{Evaluating Subsidence Assumptions}

An important factor in long-term cover performance is subsidence (Moore and Crowe, 1998). While this process could not be addressed with any of the analog sites that were part of this study, there is a need to evaluate planning assumptions that are currently being used for cover performance assessments in the Area 3 and 5 RWMSs at the NTS (DOE, 2003). 
Subsidence features have developed on operational covers and ET covers in a short period of time in the region. For example, use of Landfill Site 3 at Edwards Air Force Base (Figure 1) in the western Mojave Desert ended in 1978 with an operational cover being placed on top of construction and municipal waste disposed of in the trenches. Since its use ended, a variety of subsidence features have developed including 1) differential settlement where the cover has remained intact; 2) tensional fissures; and 3) subsidence features along the boundaries of the waste cells. In addition, the ET cover on the UC-1 Central Mud Pit (CMP) at the Central Nevada Test Area, $135 \mathrm{~km}(85 \mathrm{mi})$ northeast of Tonopah, Nevada, has experienced deformation since its construction in 2001. The CNTA landfill is one of the first two ET covers constructed by the NNSA/NSO Environmental Management Program (Bechtel Nevada, 2001). Compaction of the cover was anticipated in the first decade following construction (see http://ndep.nv.gov/cnta/cntasurfaceuclcmp.html).

\section{Adaptive Management for Cover Design at the NTS}

An alternative approach to analog sites for collecting field data on subsidence would be for NNSA/NSO, with concurrence from regulators, to allow subsidence to occur on a portion of an operational cover without maintenance. Over the course of approximately 10 years before final closure is planned for many of the cells in Area 5 of the NTS, such an experiment or adaptive management approach to waste cell closure could provide data on subsidence dynamics and rates, as well as other types of change that would occur in the early post-institutional control period. Such information could be fed into cover designs scheduled after 2011 (Bechtel Nevada, 2001).

\section{Frenchman Flat Analog Site}

There would be value in having an analog site in Frenchman Flat or elsewhere in the southern one-third of the NTS for a more direct comparison to the Area 5 RWMS. A site in the Larrea tridentata/Ambrosia dumosa shrubland as defined by Ostler et al. (2000) would probably be most valuable since it easily covers the greatest percentage of Mojave Desert ecologic region on the NTS (Figure 2).

\section{Invasive Species}

The current Bechtel Nevada (2001) for the Area 3 and Area 5 RWMS calls for allowing "shallow-rooted, invasive plant species... to vegetate the closure covers." If this strategy is followed, it is recommended that ongoing performance assessment work consider scenarios of increased fire frequency. Research on the Nevada Desert FACE Facility in Area 5 near the RWMS suggests that projected increases in carbon dioxide will favor the success and dominance of exotic annual grasses (particularly Bromus sp.), which has the potential to accelerate the fire cycle (Smith et al., 2000). As noted in vegetation surveys, even though perennial vegetation recruitment has occurred at all the primary analog sites, exotic annuals are able to establish themselves on areas of limited natural disturbance such as burrowing mounds around perennial shrubs. 


\section{REFERENCES}

Ankeny, M.D., T.C. Kaspar and R. Horton. 1988. Design for an automated tension infiltrometer. Soil Science Society of America Journal 52:893-896.

Beatley, J.C. 1969. Dependence of desert rodents on winter annuals and precipitation. Ecology 50: 721-724.

Bechtel Nevada. 1998. Geology report Area 3 Radioactive Waste Management Site, U.S. Department of Energy, Nevada Test Site, Nye County, Nevada. DOE/NV11718-195, UC-721, 43pp.

Bechtel Nevada. 1999. Geomorphic surface map of northern Yucca Flat, Nye County, Nevada. Prepared for the Department of Energy, Nevada Operations Office as part of the U10i Watershed Map.

Bechtel Nevada. 2001. Integrated closure and monitoring plan for the Area 3 and Area 5 Radioactive Waste Management Sites at the Nevada Test Site. Report for the National Nuclear Security Administration Nevada Operations Office, DOE/NV/11718-449-REV1. $78 \mathrm{pp}$.

Bechtel Nevada. 2002. Alternative landfill cover and monitoring system for landfills in arid environments. Accelerated Site Technology Deployment Closeout Report, DOE/NV/11718-779. 13pp.

Benson, C., T. Abichou, W. Albright, G. Gee and A. Roesler. 2000. Field evaluation of alternative earthen final covers. International Journal of Phytoremediation. 3(1), 1-21.

Birkeland, P.W. 1999. Soils and Geomorphology. Oxford Press, New York, 372 pp

Bolling, J.D. and L.R. Walker. 2002. Fertile island development and perennial shrubs across a Mojave Desert chronosequence. Western North American Naturalist 62 (1), 88-100.

Blom, P.E., Clark, W.H., and J.B. Johnson. 1991. Colony densities of the seed harvesting ant Pogonomyrmex salinus (Hymenoptera: Formicidae) in seven plant communities on the Idaho National Engineering Laboratory. Journal of the Idaho Academy of Science 27:2836.

Brown, G.A. and K.R. Rautenstrauch. 1995. Burrow use by desert tortoises at Yucca Mountain, Nevada. In The Desert Tortoise Council Proceedings of 1995 Symposium. Desert Tortoise Council, Inc., San Bernadino, CA.

Burt, W.H., and R.P. Grossenheider. 1980. A Field Guide to the Mammals, North America North of Mexico. Houghton Mifflin Company, New York. 289pp.

Casey, F.X.M. and N.E. Derby. 2002. Improved design for an automated tension infiltrometer. Soil Science Society of America Journal 66:64-67.

Cochran, J.R., W.E., Beyeler, D.A. Brosseau, L.H. Brush, T.J. Brown, S.H. Conrad, P.A. Davis, T. Ehrhorn, T. Feeney, B. Fogleman, D.P. Gallegos, R. Haaker, D. Kalinina, L.L. Price, D.P. Thomas and S. Wirth. 2001. Compliance assessment for the transuranic wastes in the Greater Confinement Disposal Boreholes at the Nevada Test Site. Volume 2: Performance Assessment (Version 2.0). Sandia National Laboratories Report SAND2001-2977. 
DOE, U.S. Department of Energy, 2003. National Nuclear Security Administration Nevada Site Office Environmental Management Technology Needs Update Fiscal Year 2004. 9 p.

Dreimanis, A. 1962. Quantitative gasometric determinations of calcite and dolomite by using Chittick apparatus. Journal of Sedimentary Petrology 32:520-529.

Dwyer, S.F. 1997. Cost comparison of alternative landfill final covers. Proceedings, International Containment Technology Conference, St. Petersburg, Florida. February.

Dwyer, S.F. 2001. Finding a better cover. Civil Engineering. January. 58-63.

Eagleson, P.S. 2002. Ecohydrology: Darwinian Expression of Vegetation Form and Function. Cambridge Univ. Press. New York, NY.

Fitzer, R.E., Gano, K.A., Rickard, W.H. and L.E. Rogers. 1979. Characteriztion of the Hanford 300 Area burial grounds. Task IV - biological transport. PNL-2774/UC-70, pp. 24-27.

Garner, W. and Y. Steinberger. 1989. A proposed mechanism for the formation of 'fertile islands' in the desert ecosystem. Journal of Arid Environments 16, 257-262.

Gee, G.W., A.L. Ward and M.J. Fayer. 1997. Surface barrier research at the Hanford site. Land Contamination and Reclamation 5(3): 233-238.

Gee, G.W. and D. Or. 2002. Particle-size analysis: In Dane, J.H. and G.C. Topp (eds.), Methods of Soil Analysis, Part 4. Physical Methods, Soil Science Society of America Book Series no. 5. p. 255-293.

Grayson, D.K. 1993. The Desert's Past, A Natural Prehistory of the Great Basin. Smithsonian Institution Press, Washington, D.C. 356pp.

Hamerlynck, E.P, J.R. McAuliffe, E.V. McDonald and S.D. Smith, S.D. 2002. Impacts of desert soil processes and drought on contrasting Mojave Desert shrubs. Ecology 83: 768779 .

Hickman, J.C. 1993. The Jepson Manual-Higher Plants of California. University of California Press, Berkeley.

Hillel, D. and C.H. M. van Bavel. 1976. Simulation of Profile Water Storage as Related to soil hydraulic properties. Soil Soc. Sci. Am. J. 40:807-815.

Hillel, D. 1998. Environmental Soil Physics. Academic Press. New York. 771p.

Hooten, M.M., Markwiese, J.T., Myles, T.G., Black, Paul, and R. Ryti. 2001. A literature review of biotic components, processes, and characteristics central to biotic transport modeling of soils at the Nevada Test Site. Draft. Prepared for the U.S. Department of Energy, Nevada Operations Office under Argonne National Laboratory Contract Number $1 \mathrm{~F}-00661.117 \mathrm{p}$.

Housman, D.C., S.F. Zitzer, T.E. Huxmans and S.D. Smith. 2003. Functional ecology of shrub seedling after a natural recruitment event and the Nevada Desert FACE Facility. Global Change Biology 9, 718-728.

Hunter, R. 1991. Bromus invasions on the Nevada Test Site: present status of B. rubens and B. tectorum with notes on their relationship to disturbance and altitude. Great Basin Naturalist. 51 (2): 176-182. 
Jensen, P. and M.M. Hooten. 2000. Burrowing Depths of Ant Species of the Transition Desert and Pinyon-Juniper Plant Communities of the Nevada Test Site. Neptune and Company, Inc. Document 05100-02. 11pp.

Jones, R.C. 2002. A Class III Cultural Resources Reconnaissance of the Proposed Underground Test Area ER-8-1 Well Pad and Access Road, Area 8, Yucca Flat, Nevada Test Site, Nye County, Nevada. Desert Research Institute Cultural Resource Reconnaissance Short Report No. SR012302-1, Project No. 020308. 17pp.

Levitt, D.G., B.L. Dozier, J.M. Dixon and L.T. Desotell. 1998. The influence of climate and vegetation as factors for waste cover design. Proceedings of the DOE Nevada Vadose Zone Monitoring Workshop, September 24-25, 1998, Las Vegas, Nevada.

Levitt, D.G. and T.M. Fitzmaurice. 2001. Deployment of an alternative closure cover and monitoring system at the mixed waste disposal unit U-3ax/bl at the Nevada Test Site, Bechtel Nevada. Waste Management 2001 Conference, Tucson, AZ, February 25 March 1, DOE/NV/11718-462.

Logsdon, S.D. and D.B. Jaynes. 1993. Methodology for determining hydraulic conductivity with tension infiltrometers. Soil Science Society of America Journal 57:1426-1431.

Lide, D.R. 2001. Handbook of Chemistry and Physics. $82^{\text {nd }}$ Edition. CRC Press. Boca Raton, FL.

Machette, M.N. 1985. Calcic soils of the southwestern United States. Geological Society of America Special Paper. 203. 1-21pp.

McDonald, E.V, E. Hamerlynck and J. McAuliffe. 2003. Basic research linkages among the soil-hydrologic-biologic systems common to the desert piedmonts, U.S. Army Proving Grounds. U.S. Department of Defense EPSCoR Project 40983-EV-DPS. 20pp.

McDonald, E.V. 2002. Numerical simulations of soil water balance in support of revegetation of damaged military lands in arid regions. Arid Land Research and Management 16(3) 277-291.

McDonald, E.V., L.D. McFadden and S.G. Wells. 2002. The influence of dust and lithology on the origin and evolution of desert pavements on alluvial fans. Geological Society of America Bulletin (draft).

McDonald, E.V., McFadden, L.D., and S.G. Wells. 2003. Regional response of alluvial fans to the Pleistocene-Holocene climatic transition, Mojave Desert, California. In Paleoenvironments and paleohydrology of the Mojave and southern Great Basin deserts. Enzel, Yehouda, Wells, S.G., and Nicholas Lancaster (Eds.). Geological Society of America Special Paper 368. Boulder.

McFadden, L.D., E.V. McDonald, S.G. Wells, K. Anderson, J. Quade and S.L. Forman. 1998. The vesicular layer of desert soils: Genesis and relationship to climate change and desert pavements based on numerical modeling, carbonate translocation behavior, and stable isotope and optical dating studies. Geomorphology, p. 101-145.

Moore, B.A. and B.M. Crowe. 1998. Consequences of subsidence for the Area 3 and Area 5 Radioactive Waste Management Sites, Nevada Test Site. Report DOE/NV-502 UC-600 prepared for the U.S. Department of Energy, Nevada Operations Office. 66pp.

Mohanty, B.P. and Z. Mousli. 2000. Saturated hydraulic conductivity and soil water retention properties across a soil-slope transition. Water Resources Research 36:3311-3324. 
Mualem, Y. 1976. A new model for predicting the hydraulic conductivity of unsaturated porous media. Water Resources Research 12:513-522.

Ostler, W.K., D.J. Hansen, D.C. Anderson and D.B. Hall. 2000. Classification of Vegetation on the Nevada Test Site. Bechtel Nevada Ecological Services, DOE/NV/11718-477.

Phifer, M.A. 2002. Long term capping strategy regulatory basis. U.S. Department of Energy, Environmental Management, Office of Science and Technology Development, internal report, 8pp.

Reynolds, W.D. and D.E. Elrick. 1991. Determination of hydraulic conductivity using a tension infiltrometer. Soil Science Society of America Journal 55:633-639.

Reynolds, J.F., R.A. Virginia, P.R. Kemp, A.G. De Soyza and D.C. Tremmel. 1999. Impact of drought on desert shrubs: Effects of seasonality and degree of resource island development. Ecological Monographs 69 (1), 69-106.

Ritsema, D.J., L.W. Dekker, J.M.H. Hendrickx and W. Hamminga. 1993. Preferential flow mechanism in a water repellent sandy soil. Water Resources Research 29:2183-2193.

Rhoades, J.D. 1996. Salinity: electrical conductivity and total dissolved solids. In, Sparks, D.L. ed., "Methods of Soil Analysis, Part 3: Chemical Methods," Monograph No. 5. American Society of Agronomy, Madison, WI. Pp. 417-435.

Rundel, P.W., and A.C. Gibson. 1996. Ecological Communities and Processes in a Mojave Desert Ecosystem, Rock Valley, Nevada. Cambridge University Press, Cambridge, U.K. $357 \mathrm{p}$.

Schlesinger, W.H., J.A. Raikes, A.E. Hartley and A.F. Cross. 1996. On the spatial pattern of soil nutrients in desert ecosystems. Ecology 77, 364-374.

Shafer, D.S., J.J. Miller, M.H. Young, S.C. Edwards and S.E. Rawlinson. 2002. The future through the past: the use of analog sites for design criteria and long-term performance assessment of evapotranspiration landfill covers. Proceedings of Waste Management 2002.

Shott, G.J., L.E. Barker, S.E. Rawlinson, M.J. Sully, and B.A. Moore. 1998. Performance assessment of the Area 5 RWMS at the NTS, Nye Dounty, Nevada. Bechtel Nevada. Revision 2.1. DOE/NV/11718-176.

Shott, G.J., V. Yucel, M.J. Sully, L.E. Barker, Rawlinson, S.E., and B.A. Moore. 1997. Performance assessment/composite analysis for the Area 3 RWMS at the NTS, Nye County, Nevada. Revision 2.0. DOE/NV-491. Bechtel Nevada.

Shott, G.J., Muller, C.J., Barker. L.E., Cawlfield, D.E., and F.T. Lindstrom, Linkenheil, D.G., Sully, M.J., McDowell-Boyer, L, and D.J. Thorne. 1995. Performance assessment for the Area 5 Radioactive Waste Management Site at the Nevada Test Site, Nye County, Nevada. Rev. 2. DOE/NV/11432-196.

Simunek, J., M. Sejna and M.T. van Genuchten. 1996. The HYDRUS-2D software package for simulating water flow and solute transport in two-dimensional variably saturated media. Version 1.0. IGWMC - TPS - 53, International Ground Water Modeling Center, Colorado School of Mines, Golden, CO. 
Smith, S.D., Huxman, T.E., Zitzer, S.F., Charlet, T.N., Housman, D.C., Coleman, J.S., Fenstermaker, L.K., Seemann, R.R., and R.S. Nowak. 2000. Elevated $\mathrm{CO}_{2}$ increases productivity and invasive species success in an arid ecosystem. Nature 408, pp. 79-82.

Spaulding, W.G. 1985. Vegetation and climates of the last 45,000 years in the vicinity of the Nevada Test Site, south-central Nevada. U.S. Geological Survey Professional Paper 1329. Prepared in cooperation with the U.S. Department of Energy. U.S. Government Printing Office, Washington, D.C.

Tyler, S.W., Chapman, J.B., Conrad, S.H., Hammermeister, D.P., Blout, D.O., Miller, J.J., Sully, M.J., and J.M. Ginanni. 1996. Soil-water flux in the southern Great Basin, United States: temporal and spatial variations over the last 120,000 years. Water Resources Research 32 (6): 1481-1499.

U.S. Department of Agriculture (USDA). 1999. Examination and description of soils in the field, in Soil Survey Manual, USDA-Agriculture Research Service: U.S Government Printing Office, Washington D.C.

van Devender, T.R., Thompson, R.S., and J.L. Betancourt. 1987. Vegetation history of the deserts of the southwestern North America: The nature and timing of the late WisconsinHolocene transition. In Ruddiman, W.F. and H.E. Wright, Jr. (eds). North America and adjacent oceans during the last deglaciation. Geological Society of America, Vol. K-3. Boulder.

van Genuchten, M.T. 1980. A closed-form equation for predicting the hydraulic conductivity of unsaturated soils. Soil Science Society of America Journal 44:892-898.

Warren, C.N. and R.H. Crabtree. 1986. Prehistory of the Southwestern Area. In Warren L. D'Azevedo (ed.), Handbook of North American Indians, Vol. 11, Great Basin. Smithsonian Institution, Washington, D.C., pp. 183-193.

White I. and M.J. Sully. 1992. On the variability and use of the hydraulic conductivity alpha parameter in stochastic treatments of unsaturated flow. Water Resources Research 28:209-213.

Whitford, W.G. and F.R. Kay. 1999. Biopedturbation by mammals in deserts: a review. Journal of Arid Environments 41, 203-230.

Wills, C.A. and W.K. Ostler. 2001. Ecology of the Nevada Test Site: An Annotated Bibliography. Bechtel Nevada Ecological Services, DOE/NV/11718-594.

Winkel, V.K., J.P. Angerer, D.B. Hall, M.W. Fariss and K.R. Johnejack. 1995. Plant and Burrow Animal Characteristics; Integrated Closure Program for the Area 3 and Area 5 Radioactive Waste Management Sites Nevada Test Site. Prepared for U.S. Department of Energy, Nevada Operations Office. 41pp.

Wooding, R.A. 1968. Steady infiltration from a large shallow circular pond. Water Resourc. Res. 4:1259-1273.

Yang, B., P.S. Blackwell and D.F. Nicholson. 1996. A numerical model of heat and water movement in furrow-sown water repellent sandy soils. Water Resources Research 32:3051-3061.

Young, M.H., E.V. McDonald, T.G. Caldwell, S.G. Benner. D. Meadows. 2003. Infiltration through desert pavements, Mojave Desert, CA, USA. Vadose Zone Journal. Submitted. 